\title{
PADUCAH GASEOUS DIFFUSION PLANT NORTHWEST PLUME INTERCEPTOR SYSTEM EVALUATION
}

A. D. Laase

J. L. Clausen

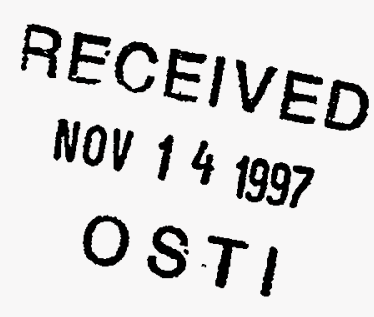

MANAGED AND OPERATED BY

LOCKHEED MARTIN ENERGY RESEARCH CORPORATION FOR THE UNTED STATES

DEPARTMENT OF ENERGY

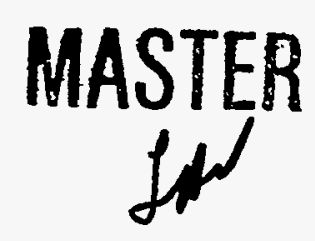

DISTAIBUTION OF THIS DOCUMENT IS UALMMTES? 


\section{DISCLAIMER}

This report was prepared as an account of work sponsored by an agency of the United States Government. Neither the United States Government nor any agency thereof, nor any of their employees, makes any warranty, express or implied, or assumes any legal liability or responsibility for the accuracy, completeness, or usefulness of any information, apparatus, product, or process disclosed, or represents that its use would not infringe privately owned rights. Reference herein to any specific commercial product, process, or service by trade name, trademark, manufac. turet, or otherwise does not necessarily constitute or imply its endorsement, recommendation, or favoring by the United States Government or any agency thereof. The views and opinions of authors expressed herein do not necessarily state or reflect those of the United States Government or any agency thereof. 
ORNL/TM-13333

\title{
PADUCAH GASEOUS DIFFUSION PLANT NORTHWEST PLUME INTERCEPTOR SYSTEM EVALUATION
}

\author{
A. D. Laase \\ J. L. Clausen
}

\begin{abstract}
Prepared by
Oak Ridge National Laboratory

Grand Junction, Colorado Managed by
\end{abstract}

LOCKHEED MARTIN ENERGY RESEARCH CORP.

$$
\text { and }
$$

Environmental Management and Enrichment Facilities

Managed by

LOCKHEED MARTIN ENERGY SYSTEMS, INC.

for the

U.S. DEPARTMENT OF ENERGY

under contract DE-AC05-96OR22464 


\section{FIGURES}

1.1 Northwest Plume interceptor system well fields $\ldots \ldots \ldots \ldots \ldots \ldots \ldots \ldots 1-2$

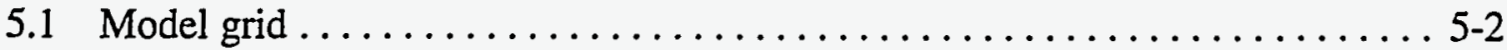

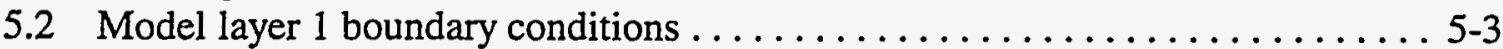

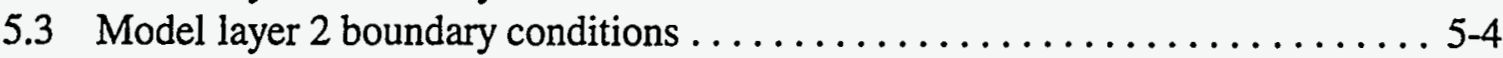

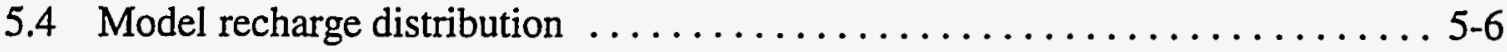

5.5 Location of well fields in the model domain $\ldots \ldots \ldots \ldots \ldots \ldots \ldots \ldots .7$

5.6 Model layer 1 hydraulic conductivity distribution $\ldots \ldots \ldots \ldots \ldots \ldots \ldots .5-9$

5.7 Model layer 2 hydraulic conductivity distribution $\ldots \ldots \ldots \ldots \ldots \ldots \ldots .6 \ldots$

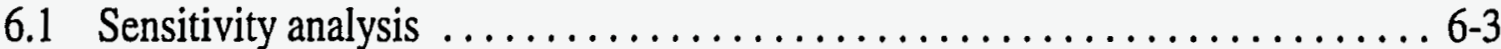

6.2 Potentiometric surface of the UCRS on August 15, $1991 \ldots \ldots \ldots \ldots \ldots 6-10$

6.3 Model predicted UCRS potentiometric surface $\ldots \ldots \ldots \ldots \ldots \ldots \ldots \ldots 6-11$

6.4 Potentiometric surface of the RGA on August 15, $1991 \ldots \ldots \ldots \ldots \ldots \ldots 6-12$

6.5 Model predicted RGA potentiometric surface $\ldots \ldots \ldots \ldots \ldots \ldots \ldots \ldots 6-13$

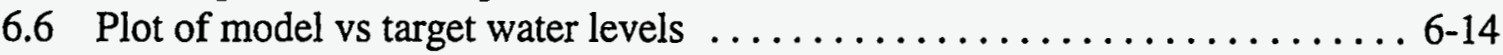

6.7 Particle traces from source areas to the Ohio River $\ldots \ldots \ldots \ldots \ldots \ldots \ldots .6-15$

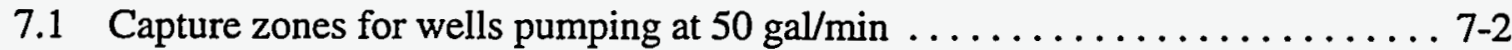

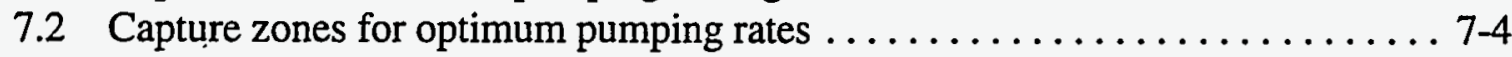

7.3 Capture zone for south well field pumping at optimum rates $\ldots \ldots \ldots \ldots \ldots 7-7$

\section{TABLES}

6.1 Model parameter values and sensitivity and correlation status . . . . . . . . 6-2

6.2 Water-level calibration targets and calibration results for the model ........6-6 6

6.3 Lump sum calibration statistics $\ldots \ldots \ldots \ldots \ldots \ldots \ldots \ldots \ldots \ldots \ldots .6 .6$

7.1 Model calibrated, minimum, and maximum input parameter values, $\mathrm{ft} / \mathrm{d} \ldots \ldots$ 7-5 


\section{PREFACE}

The capture zone analysis report for the Northwest Plume was performed under Work Breakdown Structure 7.1.02.18.04 (Activity Data Sheet 5311). This document provides information related to the evaluation of capture zone effectiveness for the Northwest Plume well fields using a numerical flow model. 


\subsection{INTRODUCTION}

The Paducah Gaseous Diffusion Plant (PGDP) Northwest Plume Record of Decision (ROD) states groundwater will be pumped at a rate to reduce further contamination and initiate control of the northwest contamination plume (U.S. DOE 1993). Based on the ROD, four interceptor wells evenly divided between the north and south well fields were installed at the site (Fig.1.1). The initial design study, based on a hydraulic conductivity of $425 \mathrm{ft} / \mathrm{d}$, suggested pumping rates of $100 \mathrm{gal} / \mathrm{min}$ per well field would be sufficient for plume containment (Douthitt and Philips 1994). However, during system startup hydraulic conductivities up to $8000 \mathrm{ft} / \mathrm{d}$ were estimated in the vicinity of the north well fields (Phillips 1996). The higher than expected hydraulic conductivities raised concerns that the interceptor system, operating as designed, would not be capable of containing the plume. Initial examination of water levels and contaminant concentrations in the vicinity of the two well fields demonstrated that due to the limited number of observation wells it was not possible to characterize well-field capture zones. To alleviate concerns, this study was commissioned to evaluate the capture zones of the north and south well fields operating at the design pumping rate of $100 \mathrm{gal} / \mathrm{min}$ per well field. Modified pumping rates capable of plume containment were to be determined if the design pumping rate proved deficient.

This report is organized as follows:

- Section 2 describes the project technical approach.

- Section 3 presents the site hydrogeologic conceptual model which serves as the framework for this study.

- Section 4 provides the rationale for model code selection.

- Sections 5 and 6 describe model configuration and calibration, respectively.

- Section 7 presents simulation results for various pumping scenarios.

- Section 8 discusses model strengths and limitations.

- Sections 9 and 10 present study conclusions and recommendations, respectively.

It is important to note that model predictions are in part a function of model configuration. Models configured differently can satisfy the same calibration criteria but yield different predictive results. In contrast to other site model configurations, this model includes a continuous higher hydraulic conductivity zone between the north and south well fields and anthropogenic recharge from the 001 Outfall ditch. It is possible that other model configurations that do not include these features can satisfy the same calibration criteria but result in different conclusions. Thus, results of this evaluation may not be unique. 


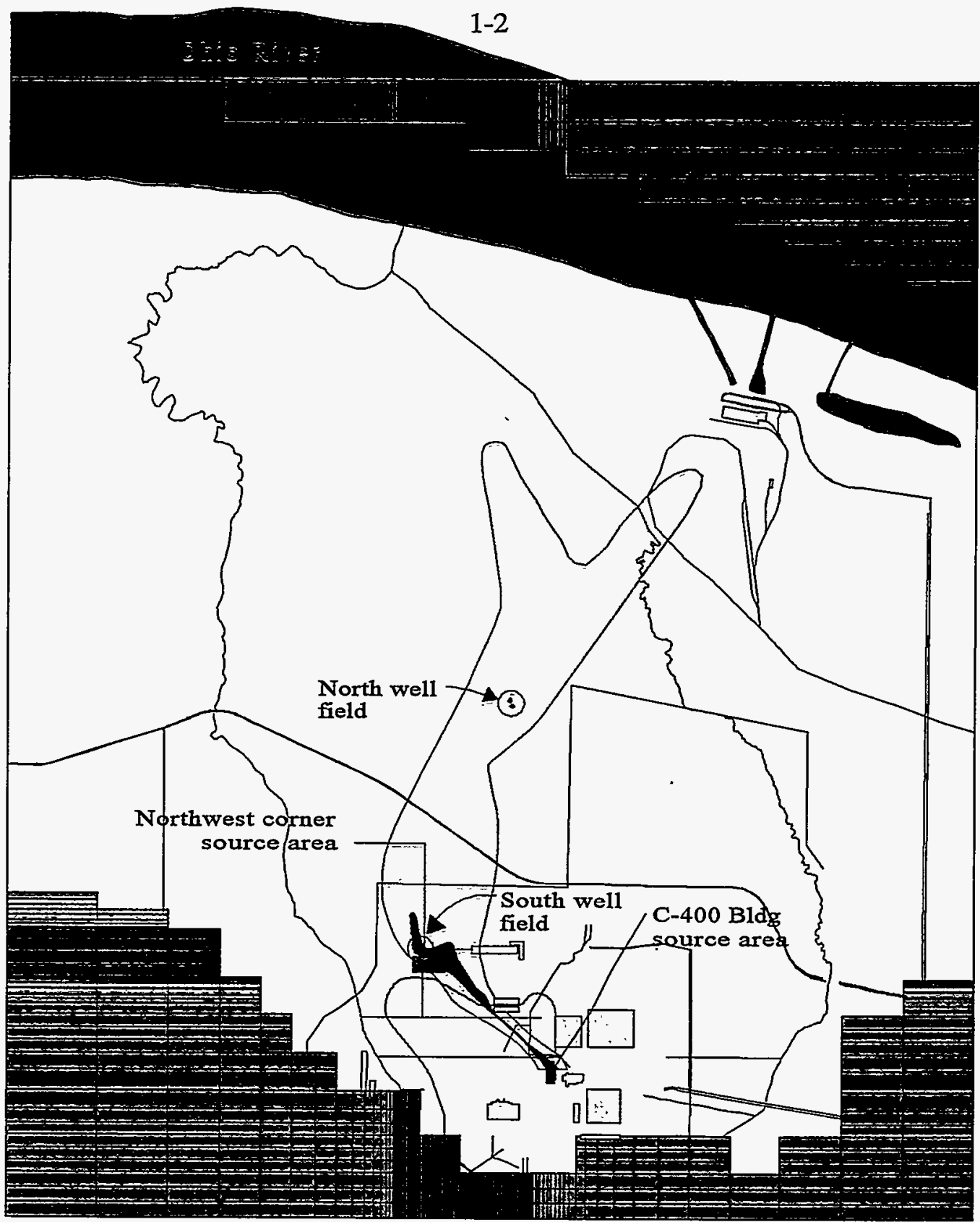

Paducah Gaseous Diffusion Plant

plumfiel

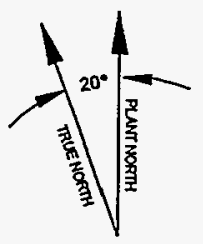

Paducah, Kentucky

\section{Legend}

VOC concentrations, $>10 \mathrm{ug} / 1$
VOC concentrations, $>1,000 \mathrm{ug} / 1$
$\square$ Rivers and streams
Buildings
No Flow Cells
Source areas

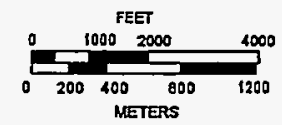

Fig. 1.1. Northwest Plume interceptor system well fields. 


\subsection{TECHNICAL APPROACH}

Higher than expected hydraulic conductivities (Phillips 1996) in the vicinity of the north and south well fields raised concerns that the Northwest Plume interceptor system, as presently operating, might not be containing groundwater contamination. To evaluate the impact of higher than expected hydraulic conductivities on capture zone geometries, the use of a sophisticated 3-dimensional groundwater flow and particle tracking model was suggested. Other approaches for evaluating plume hotspot containment such as potentiometric surface mapping and contaminant monitoring have proven ineffective due to the limited number of observation wells and minimal drawdown. To expedite evaluation, an existing 3-dimensional groundwater model was modified and used to perform the capture zone analysis (GeoTrans 1993). Details concerning model modification are presented in Sect. 5. After model modification, the model was calibrated by adjusting model input hydraulic conductivity and recharge parameter values until a reasonable match between observed (target) and model water-level elevations and plume geometry and particle traces were achieved. Model calibration procedures and results can be found in Sect. 6 . Once calibrated, the model was used to predict the capture zones for the Northwest Plume interceptor system for various pumping scenarios including the current pumping regime. Section 7 contains capture zone analysis details. Based on model-predicted capture zones, modification to the present pumping regime were proposed. 


\subsection{CONCEPTUAL MODEL}

Three hydrogeologic units, the upper continental recharge system (UCRS), the regional gravel aquifer (RGA), and the McNairy Formation, are present at the PGDP. Complete description of the geologic subunits composing these hydrogeologic units can be found in Clausen et al. (1992 and 1995). The UCRS is approximately $50 \mathrm{ft}(15.2 \mathrm{~m})$ thick and is primarily composed of clay and silt with interbedded sand and gravel lenses. Measured UCRS hydraulic conductivities ranging from $5.9 \times 10^{-4}$ to $13.9 \mathrm{ft} / \mathrm{d}\left(2.1 \times 10^{-7}\right.$ to $4.9 \times$ $10^{-3} \mathrm{~cm} / \mathrm{s}$ ) reveal the heterogeneity of this hydrogeologic unit. The bulk UCRS hydraulic conductivity is believed to be around $1.0 \mathrm{ft} / \mathrm{d}\left(3.5 \times 10^{-4} \mathrm{~cm} / \mathrm{s}\right)$ (GeoTrans 1992). Below the UCRS is the RGA, which ranges in thickness from 0 to $50 \mathrm{ft}$ (0 to $15.2 \mathrm{~m})$. Typical RGA hydraulic conductivities range between 50 to $1200 \mathrm{ft} / \mathrm{d}\left(1.8 \times 10^{-2}\right.$ to $\left.0.4 \mathrm{~cm} / \mathrm{s}\right)$ (Douthitt and Phillips 1994) with a bulk hydraulic conductivity of $425 \mathrm{ft} / \mathrm{d}(0.15 \mathrm{~cm} / \mathrm{s})$ (GeoTrans 1992). Hydraulic conductivities of up to $8000 \mathrm{ft} / \mathrm{d}(2.8 \mathrm{~cm} / \mathrm{s})$ have been estimated in a higher hydraulic conductivity zone in the vicinity of the north and south well fields (Phillips 1996). Because of the hydraulic conductivity contrast between the UCRS and RGA, groundwater flow is primarily vertical in the UCRS (Clausen et al. 1992 and 1995). Beneath the lower continental deposits resides the McNairy Formation which is composed of several hundred feet of fine sand, silt, and clay. Although the McNairy hydraulic conductivity has never been directly measured, based on analytical analysis the McNairy is thought to be much less conductive than the RGA (Davis 1994).

The UCRS and RGA hydrogeological units are bounded to the south by the Porters Creek Clay, a relatively impermeable unconformity (Clausen et al. 1992 and 1995). The Ohio River, located north of the site, is thought to be the ultimate discharge location for the majority of PGDP groundwater. There are no known hydrologic boundaries affecting the PGDP hydrogeologic units immediately east and west of the site.

Groundwater inflow to the PGDP hydrogeologic units comes from a combination of natural and anthropogenic recharge. Previous modeling studies estimated natural recharge at 4.7 in./year (11.9 cm/year) (McConnel 1992; GeoTrans 1992). Anthropogenic recharge associated with leaking underground fire protection and water supply lines, drainage ditches, and roof drains has never been quantified but is believed to be greater than natural recharge in the immediate vicinity of the PGDP (U.S. DOE 1996). 


\subsection{MODEL CONFIGURATION}

This model was configured by modifying an existing groundwater model constructed by GeoTrans (GeoTrans 1992). The following sections discuss changes made to the GeoTrans model during model configuration. For brevity and to avoid repetitive discussions, wherever possible, references are made to the GeoTrans report.

\subsection{MODEL DISCRETIZATION}

To better simulate pumping of the two well fields, 52 rows and 11 columns were added to the GeoTrans model resulting in a 169 row $\times 102$ column model grid (Fig. 5.1). A minimum $50 \times 50-\mathrm{ft}$ grid size was used in the vicinity of the pumping wells and was expanded to a maximum of $900 \times 2200 \mathrm{ft}$ at the Ohio River. Two layers representing the UCRS and RGA were used in the model rather than the three used in the GeoTrans model. The third layer in the GeoTrans model represented the McNairy formation. Analysis of the GeoTrans model water budget showed that only three to four percent of the water entering the RGA discharged to the McNairy. Additionally, particle tracking modeling showed that, according to the GeoTrans model, none of the contamination emanating from the C-400 and Northwest corner source areas reached the McNairy. Thus, the McNairy, as modeled by GeoTrans, had minimal influence on the flow system or contaminant transport and could be removed from the model without significantly affecting model results. GeoTrans established appropriate top and bottom elevations for the model layers from lithologic logs (GeoTrans 1992). The bottom of the RGA represents the bottom of the model. The model grid is oriented on the PGDP coordinate system.

\subsection{BOUNDARY CONDITIONS}

The following briefly discusses the various boundary conditions used in this model. All boundary conditions are identical to the boundary conditions used in the GeoTrans model (GeoTrans 1992). The rationale for selecting and assigning the various boundary conditions can be found in the GeoTrans report.

No-flow boundaries present in both model layers were assigned to the terrace face of the Plio-Pleistocene erosional surface along the southern edge of the model and on the northern side of the Ohio River (Figs. 5.2 and 5.3). The east and west sides of the model represent no-flow boundaries. 


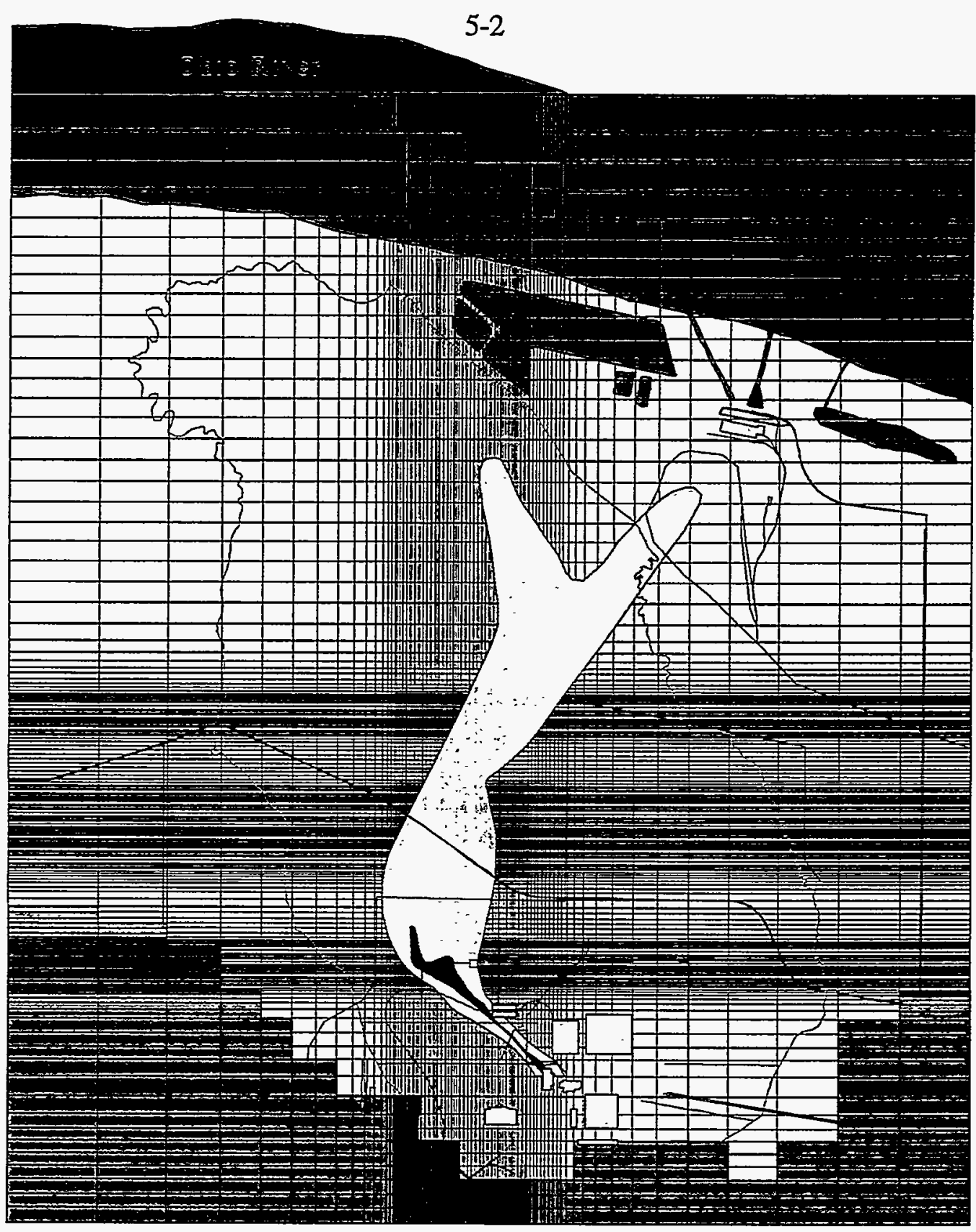

Paducah Gaseous Diffusion Plant

L2calbnd Paducah, Kentucky

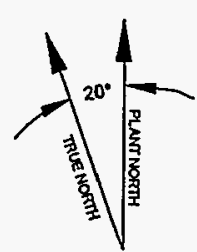

Legend

$\square$ VOC concentrations, $>10 \mathrm{ug} / 1$

VOC concentrations, $>1,000 \mathrm{ug} / 1$

$\rightarrow$ Rivers and streams

$\square$ Buildings

No Flow Cells

Fig. 5.1. Model grid. 


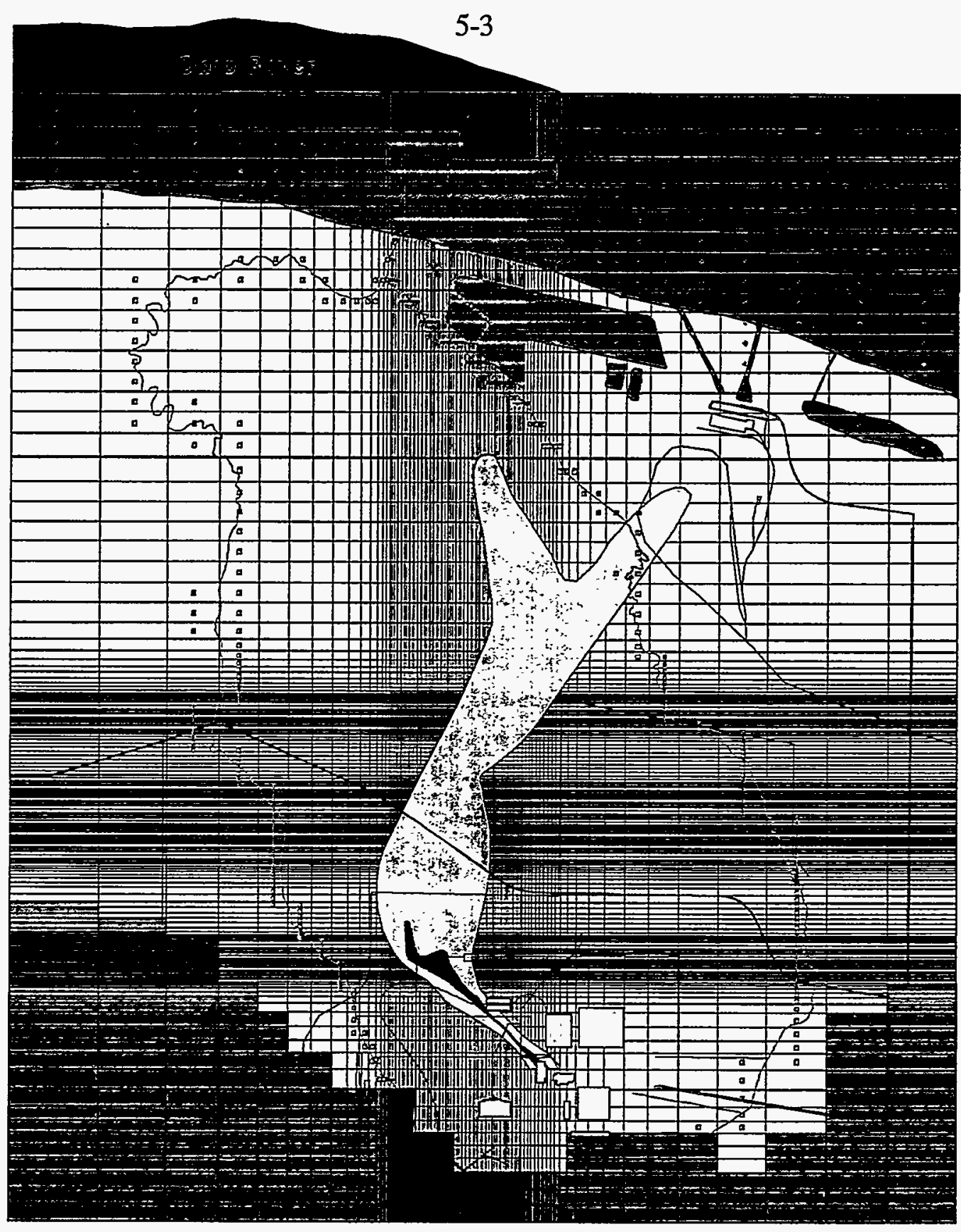

Paducah Gaseous Diffusion Plant

ticatbod Paducah, Kentucky

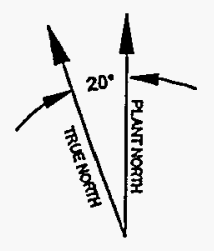

Legend

$\square$ VOC concentrations, $>10 \mathrm{ug} / 1$

VOC concentrations, > 1,000 ug/1

Rivers and streams

$\square$ Buildings

No Flow Cells

- Constant head boundaries

a River cells

Fig. 5.2. Model layer 1 boundary conditions.

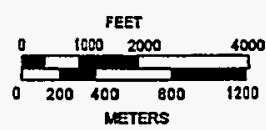




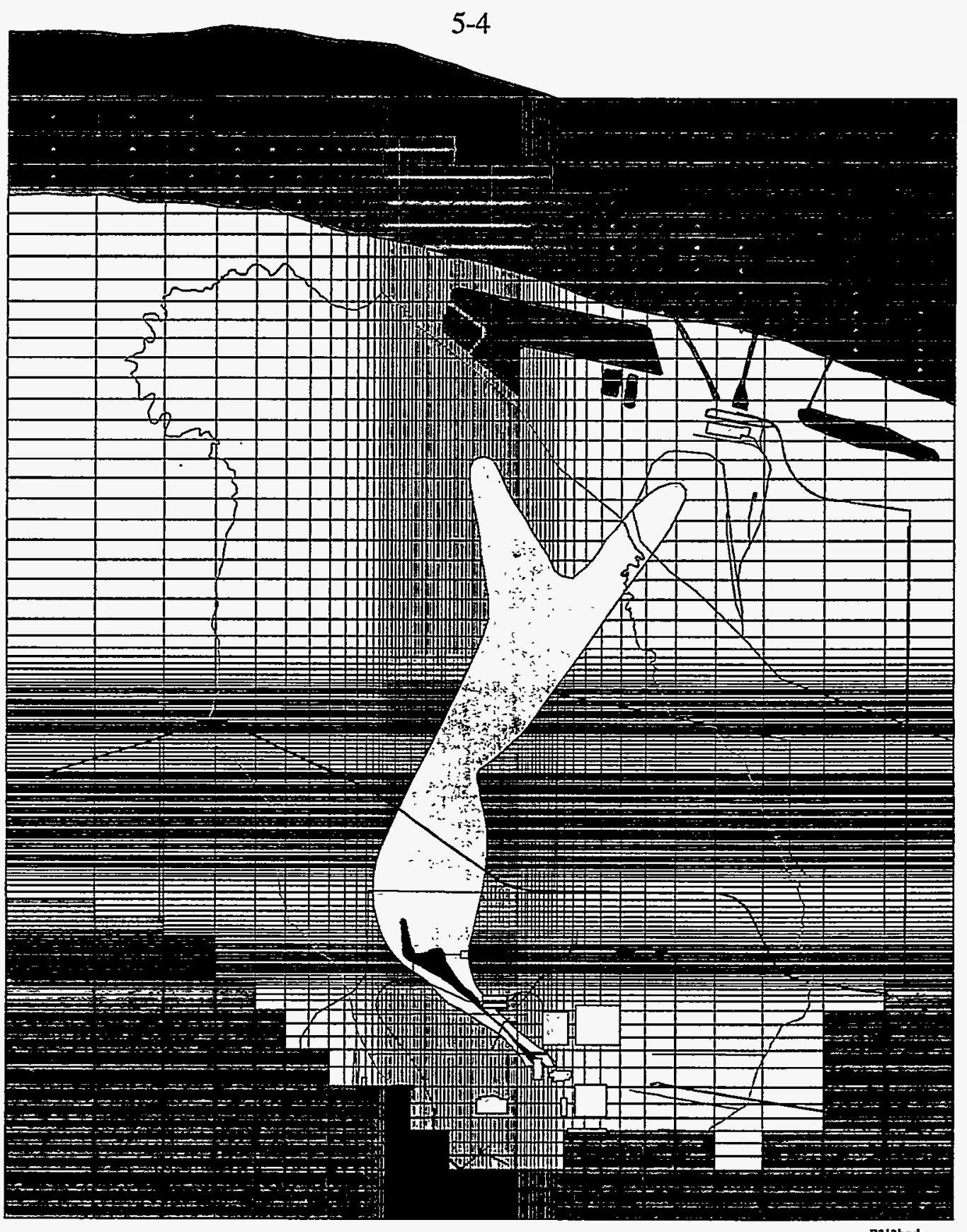

Paducah Gaseous Diffusion Plant

F312bnd Paducah, Kentucky

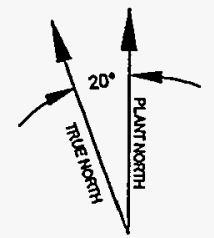

Legend

\author{
$\square$ VOC concentrations, $>10 \mathrm{ug} / 1$ \\ VOC concentrations, $>1,000 \mathrm{ug} / 1$ \\ - Rivers and streams \\ $\square$ Buildings \\ No Flow Cells \\ - Constant head boundary
}

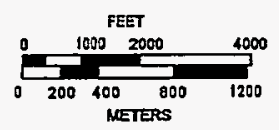

Fig. 5.3. Model layer 2 boundary conditions. 
The Ohio River, the settling pond at Tennessee Valley Authority (TVA), and Metropolis Lake are represented as constant head boundaries in the model. The Ohio River constant head boundary, which functions as the primary discharge location in the model, extends into both model layers and is assigned a constant head value of $290 \mathrm{ft}$ (Figs. 5.2 and 5.3). Constant head boundaries representing the TVA settling pond and Metropolis Lake are located solely in model layer 1 and are assigned constant head values of $346 \mathrm{ft}$ and $314 \mathrm{ft}$, respectively (Fig. 5.2).

Big and Little Bayou Creeks were specified in model layer 1 with MODFLOW's River package (Fig. 5.2). The River package simulates rivers, streams, or creeks as headdependent boundaries whose base is the bottom of the surface water feature.

\subsection{GROUNDWATER SOURCES AND SINKS}

Unlike the GeoTrans model, which utilized a single recharge zone representing recharge from precipitation, recharge was applied to two zones within the model (Fig. 5.4).

Similar to the GeoTrans model, the first zone corresponds to recharge from precipitation, termed natural recharge. The second zone represents anthropogenic recharge which is known to occur, but at present, has not been characterized (U.S. DOE 1996). Anthropogenic recharge at the PGDP is expected to come from leaking underground utility lines, roof drains, and ditches. A number of anthropogenic recharge scenarios were evaluated during model configuration and calibration. Scenarios evaluated include configuring all of the facility and only those portions of the facility having. water levels less than $10-\mathrm{ft}$ below ground surface as anthropogenic recharge zones. The best match of particle traces to plume geometry occurred when only the 001 Outfall ditch was simulated as a source of anthropogenic recharge. Average flow in the unlined 001 Outfall ditch from 1987 through February 1996 was 1.9 million gallons per day (Mgd). During August 1991, the period against which the model was calibrated, average discharge was $1.4 \mathrm{Mgd}$. The potential for significant recharge to occur from the 001 Outfall ditch is great because the ditch is unlined and transmits a large quantity of water. No recharge was applied to a third zone representing areas of the PGDP where buildings and pavement are present. Predicted recharge rates for the two zones are presented in Sect. 6 .

Four RGA interceptor wells, two each in the north and south well fields, are located within the model domain (Fig. 5.5). Each of the interceptor wells currently pumps at approximately $50 \mathrm{gal} / \mathrm{min}\left(9625 \mathrm{ft}^{3} / \mathrm{d}\right)$ for a combined total of $200 \mathrm{gal} / \mathrm{min}\left(38,500 \mathrm{ft}^{3} / \mathrm{d}\right)$, which is the maximum design capacity of the treatment system. 


\section{$5-6$}

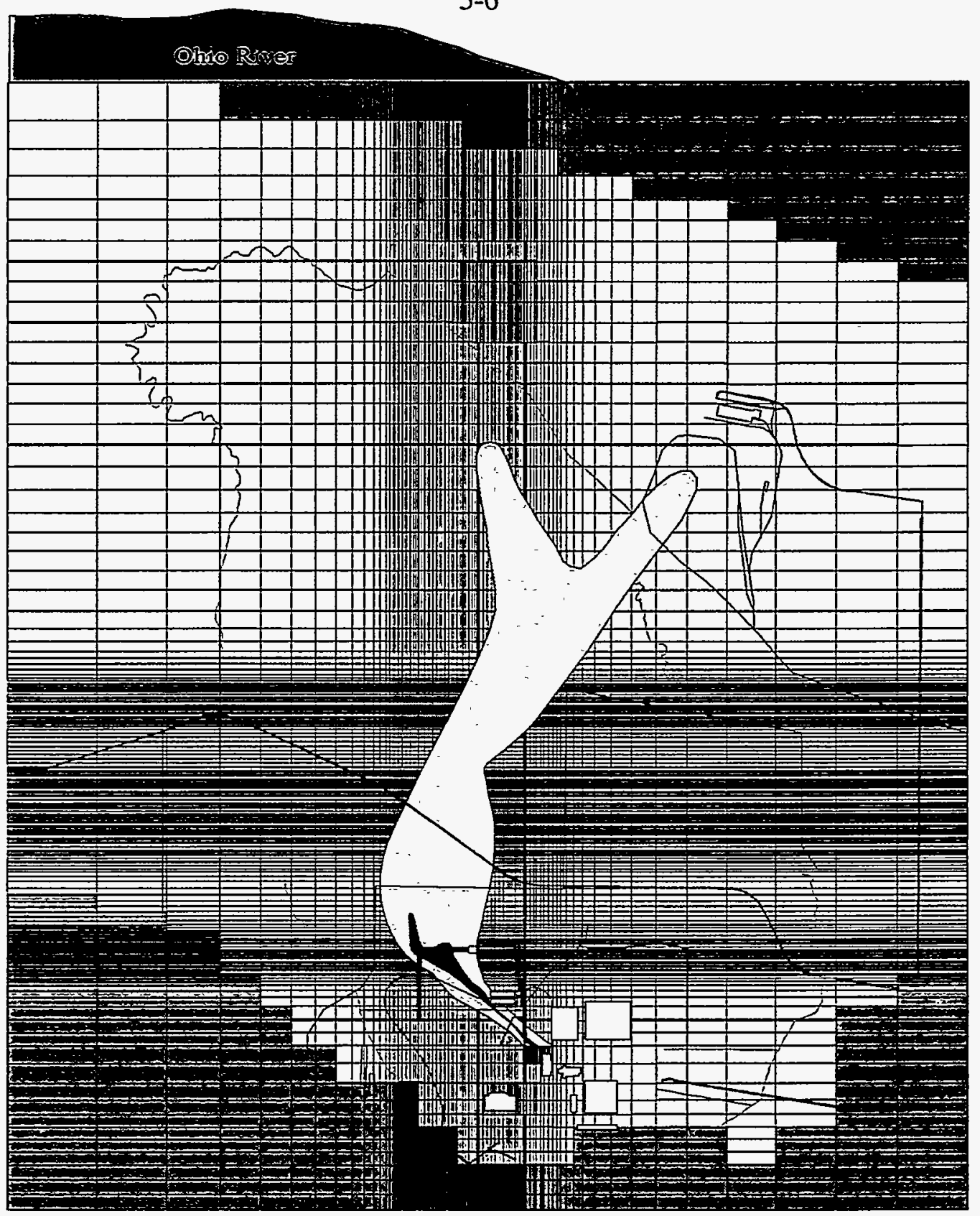

Paducah Gaseous Diffusion Plant

Li calree Paducah, Kentucky

Legend

\begin{tabular}{|c|c|c|c|c|c|}
\hline \multirow{3}{*}{ 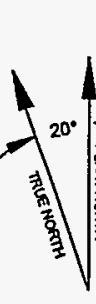 } & \multicolumn{2}{|c|}{$\begin{array}{l}\text { Rivers and streams } \\
\text { Buildings } \\
\text { No Flow Cells }\end{array}$} & \multicolumn{2}{|c|}{$\begin{array}{l}\text { VOC concentrations, }>10 \mathrm{ug} / 1 \\
\text { VOC concentrations, }>1,000 \mathrm{ug} / 1\end{array}$} & \multirow[b]{2}{*}{$\begin{array}{cc}\text { FEET } \\
0 \quad 1000 \quad 2000 \\
0\end{array}$} \\
\hline & Parameter & $\begin{array}{l}\text { Calibrated } \\
\text { value, } \mathrm{ft} / \mathrm{d}\end{array}$ & Parameter & $\begin{array}{l}\text { Calibrated } \\
\text { value, ft/d }\end{array}$ & \\
\hline & $\begin{array}{l}\text { Natural } \\
\text { recharge }\end{array}$ & $8.76 \times 10 \mathrm{E}-4$ & $\begin{array}{l}\text { Anthropogenic } \\
\text { recharge } \\
\text { No recharge }\end{array}$ & $\begin{array}{l}2.43 \times 10 \mathrm{E}-2 \\
0.00\end{array}$ & $\underbrace{800}_{0.200} 1200$ \\
\hline
\end{tabular}

Fig. 5.4. Model recharge distribution. 


\section{$5-7$}

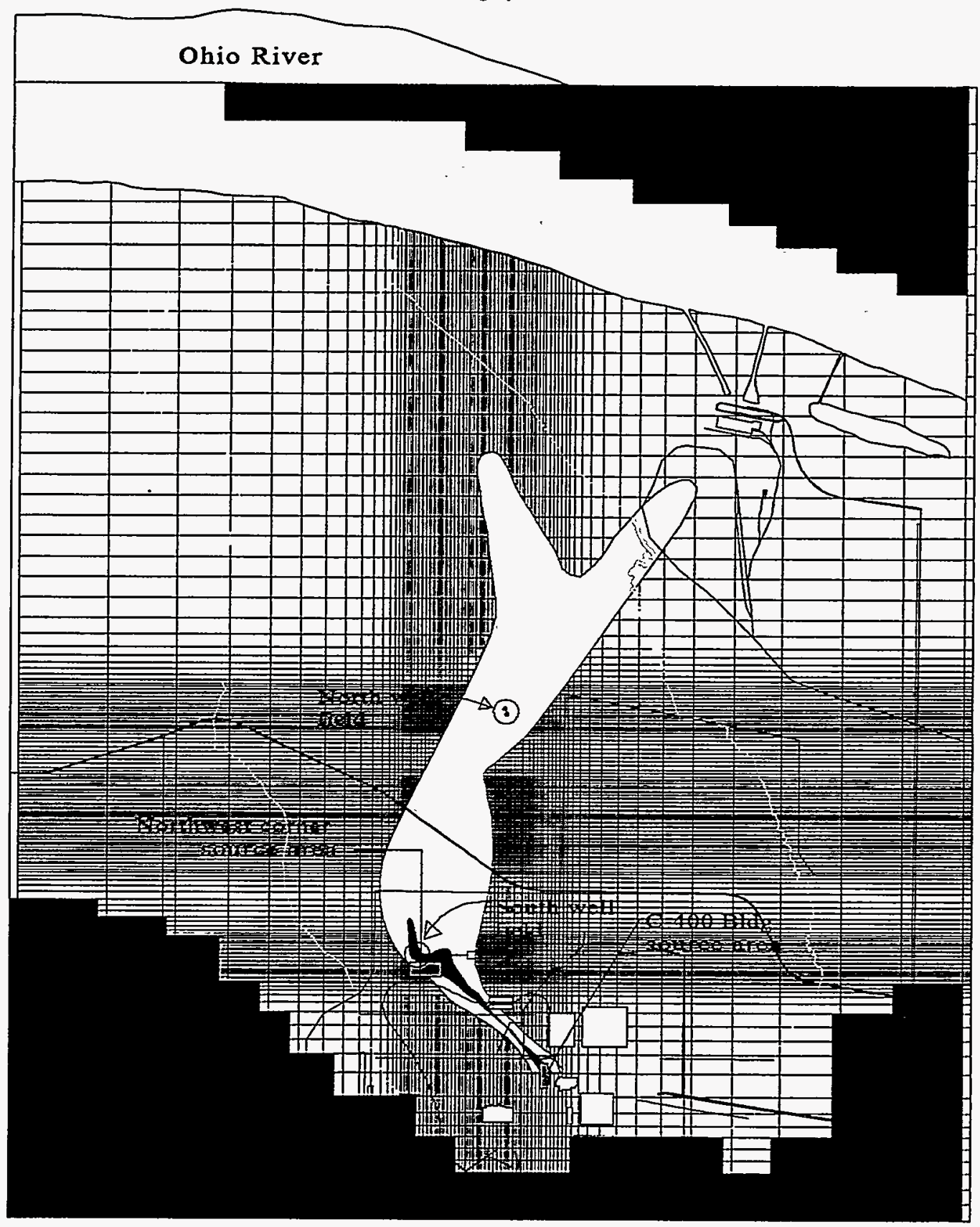

Paducah Gaseous Diffusion Plant

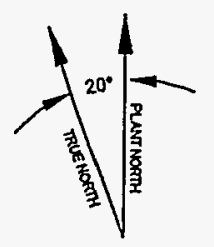

$$
\text { Paducah, Kentucky }
$$

Legend

$\square$ VOC concentrations, $>10 \mathrm{ug} / 1$

- VOC concentrations, $>1,000 \mathrm{ug} / 1$ Rivers and streams

$\square$ Buildings

No Flow Cells

Dource areas plumfiel

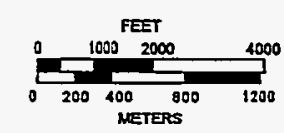

Fig. 5.5. Location of well fields in the model domain. 


\subsection{HYDRAULIC CONDUCTIVITY}

Six hydraulic conductivity zones, two in model layer 1 and four in model layer 2, were used in the model (Figs. 5.6 and 5.7). With the exception of the two hydraulic conductivity zones representing the higher RGA hydraulic conductivity zone, inferred from the Northwest Plume aquifer test (Phillips 1996), the distribution of the various hydraulic conductivity zones in this model is similar to the GeoTrans model. The location and geometry of the higher hydraulic conductivity zone were determined from lithologic information, aquifer test results, and plume geometry. The two hydraulic conductivity zones within the higher hydraulic conductivity zone are based on aquifer test results and are an attempt to simplify a complex hydrogeologic system. Hydraulic conductivity values used in the model are presented in Sect. 6 . 


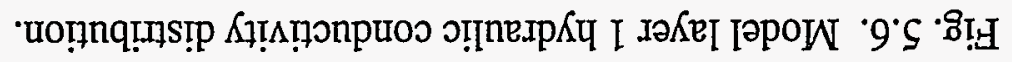

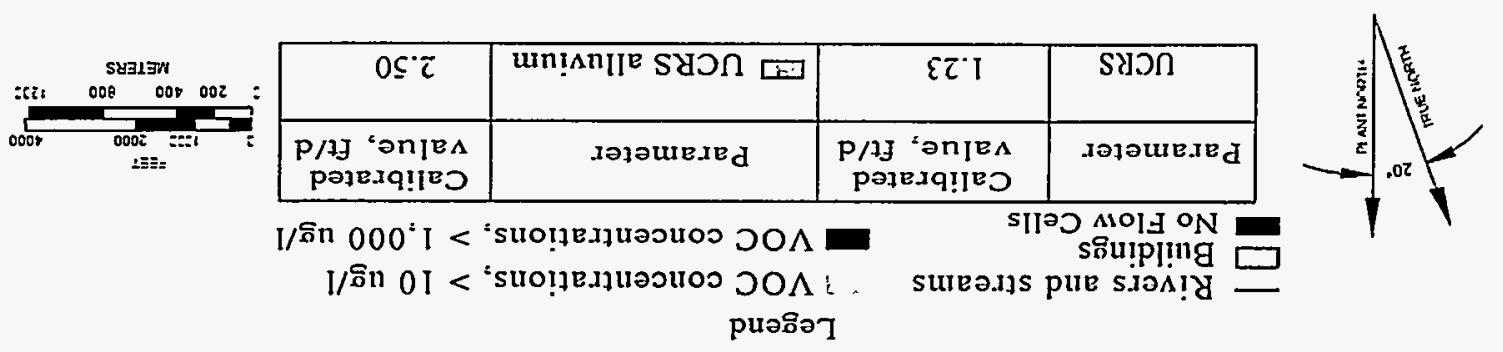

«รonjuəy 'yeonped

דובוּ

jueld torsnjy!d snoosed yeanped

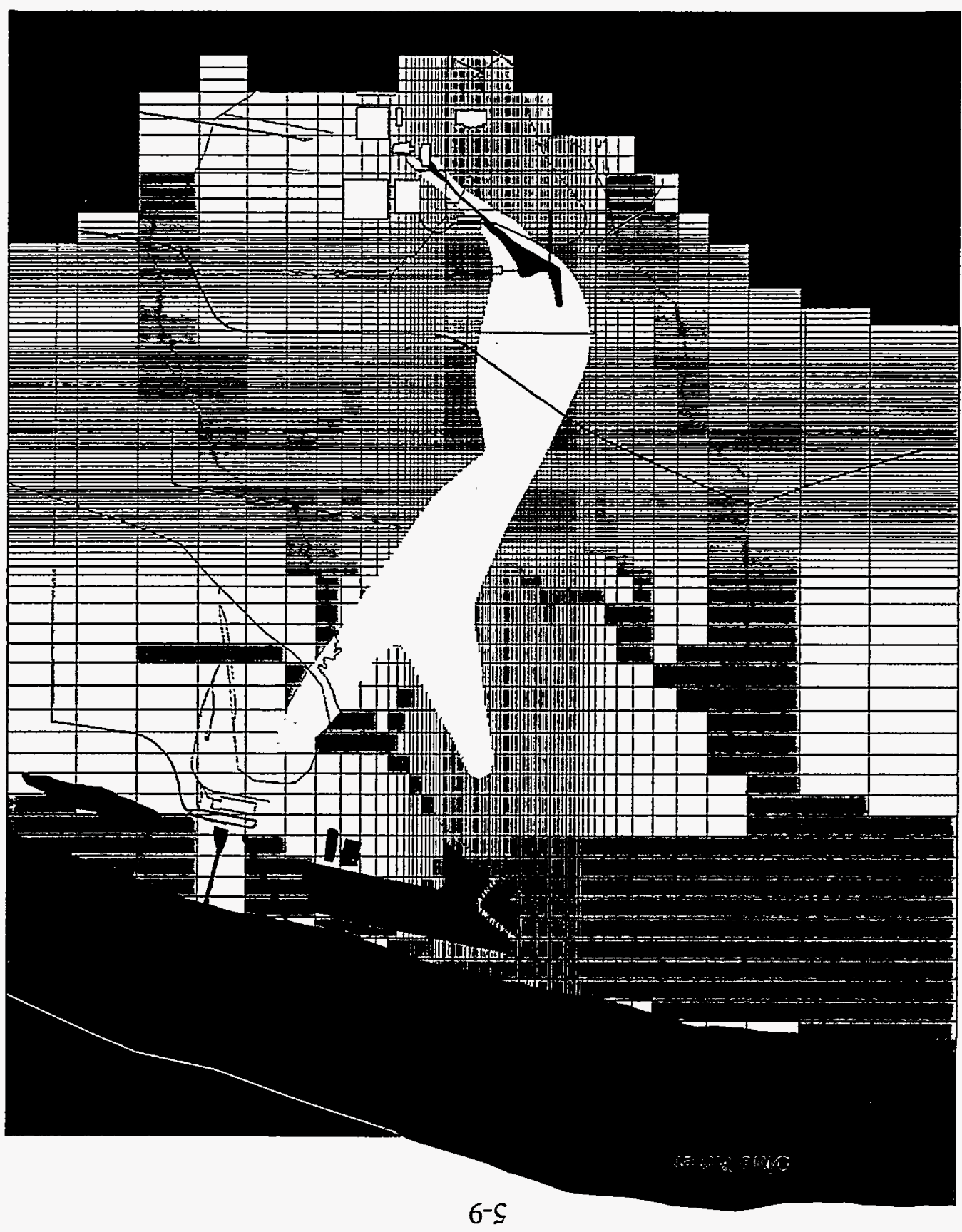




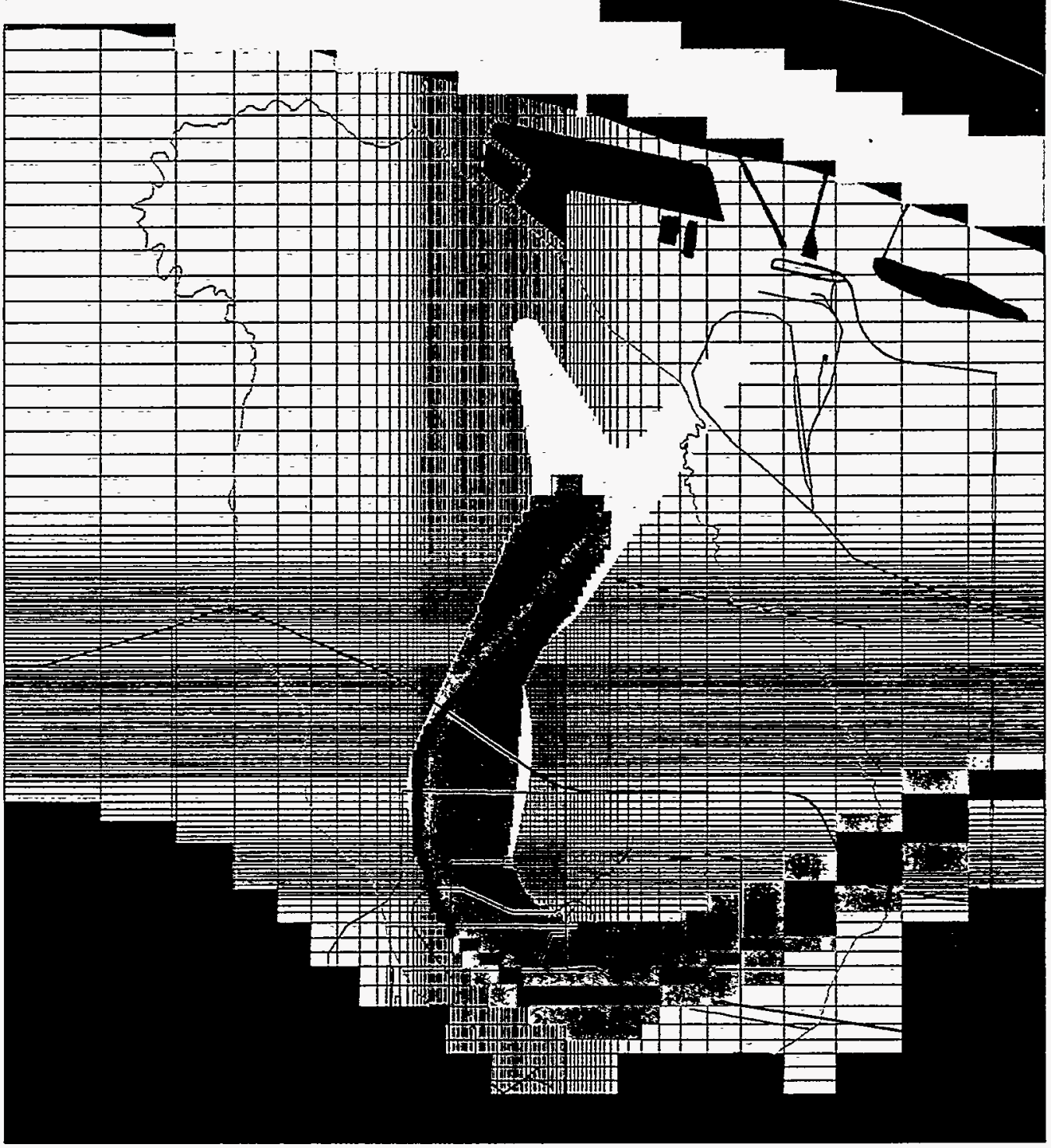

Paducah Gaseous Diffusion Plant Paducah, Kentucky

Legend

$\because \mathrm{VOC}$ concentrations, $>10 \mathrm{ug} / \mathrm{l}$

〜 Rivers and streams Buildings

VOC concentrations, $>10,000 \mathrm{ug} / \mathrm{l}$

no Flow Cells

\begin{tabular}{|c|c|c|c|c|}
\hline \multirow{4}{*}{ 㿣 } & Parameter & \begin{tabular}{|l|} 
Calibrated \\
value, $\mathrm{ft} / \mathrm{d}$
\end{tabular} & Parameter & $\begin{array}{l}\text { Calibrated } \\
\text { value, } \mathrm{ft} / \mathrm{d}\end{array}$ \\
\hline & $\cdots \mathrm{RGA}$ & 425.00 & & \\
\hline & \multirow{2}{*}{$\begin{array}{l}\text { RGA - } \\
\text { Ohio River }\end{array}$} & \multirow[b]{2}{*}{21.40} & $\square$ RGA - channel edges & 2500.00 \\
\hline & & & RGA - channel middle & 5000.00 \\
\hline
\end{tabular}

Fig. 5.7. Model layer 2 hydraulic conductivity distribution. 


\subsection{MODEL CALIBRATION}

The following sections discuss calibration procedure, estimates of aquifer properties, predicted water levels, and plume flow paths.

\subsection{CALIBRATION PROCEDURE}

The model was calibrated to August 15, 1991 water-level elevations and to the Northwest Plume geometry. The rationale for selecting these target water-level elevations can be found in the GeoTrans modeling report (GeoTrans 1992). During model calibration, parameter values representing hydraulic conductivity and recharge zones were adjusted to produce a model that best approximated target water-level elevations from 75 UCRS and RGA wells. Additionally, model input parameters were adjusted to obtain the best match between the Northwest plume geometry and particle traces originating from known contaminant sources. Any model that could not replicate the Northwest plume geometry, regardless of the match between target and model predicted heads, was discarded. The rationale was that if the model could not simulate plume geometry then the model could not be used for capture zone evaluation.

Parameter estimation using a non-linear regression technique developed by Doherty et al. (1994) was used to obtain estimates and 95\% confidence intervals for all sensitive, noncorrelated model input parameters. Table 6.1 lists model parameters and sensitivity and correlation status. A parameter is considered sensitive when changes in the parameter value produce measurable changes in the calibration error of the model, the difference between measured and model results. For example, both natural and anthropogenic recharge are sensitive parameters (Fig. 6.1). Small percentage changes in recharge rates produce measurable changes in the model calibration error.

Nonsensitive parameters have little or no influence on the model calibration error for all reasonable input values. An example of an insensitive parameter within the model is the hydraulic conductivity of the UCRS alluvium in the vicinity of the Big and Little Bayou Creeks (Fig. 6.1). Large percentage changes in UCRS alluvium hydraulic conductivity result in minimal changes in model calibration error, the difference between target and model heads. Because the nonsensitive parameters could not be estimated, reasonable values were determined from available data and held constant during model calibration (Table 6.1).

Correlated parameters have an optimum value that is dependent on the value of another model parameter. For example, in a Darcy column there are an infinite combination of discharge (recharge) and hydraulic conductivity values that will result in the same hydraulic head distribution. Because discharge and hydraulic conductivity are correlated, to 
Table 6.1. Model parameter values and sensitivity and correlation status

\begin{tabular}{|c|c|c|c|}
\hline Parameter & $\begin{array}{l}\text { Parameter } \\
\text { value, } \mathrm{ft} / \mathrm{d}\end{array}$ & Sensitive & Correlated \\
\hline UCRS hydraulic conductivity & 1.23 & $\therefore$ Yes & No. \\
\hline UCRS alluvium hydraulic conductivity & 2.5 & No & No \\
\hline RGA hydraulic conductivity & 425.0 & Yês & No. \\
\hline $\begin{array}{l}\text { RGA at the Ohio River hydraulic } \\
\text { conductivity }\end{array}$ & 21.4 & Yes & Yes* \\
\hline RGA channel edges hydraulic conductivity & 2500.0 & Yes & Yes* \\
\hline $\begin{array}{l}\text { RGA channel middle hydraulic } \\
\text { conductivity }\end{array}$ & 5000.0 & No & No \\
\hline Natural recharge & $8.76 \times 10^{4}$ & Yes & No \\
\hline Anthropogenic recharge & $2.43 \times 10^{2}$ & Yes & No \\
\hline Vertical RGA hydraulic conductivity** & $8.75 \times 10^{-4}$ & Yes*** & No \\
\hline
\end{tabular}

Shaded text indicates parameters that can be and were estimated using parameter estimation techniques.

* These parameters were correlated to all other input parameters.

** All other hydraulic conductivities were assumed to be $10 \%$ of the corresponding horizontal hydraulic conductivity.

*** Proved to be so sensitive that small charges resulted in large increases in model calibration error, the difference between target and model heads. 
Sensitivity Analysis

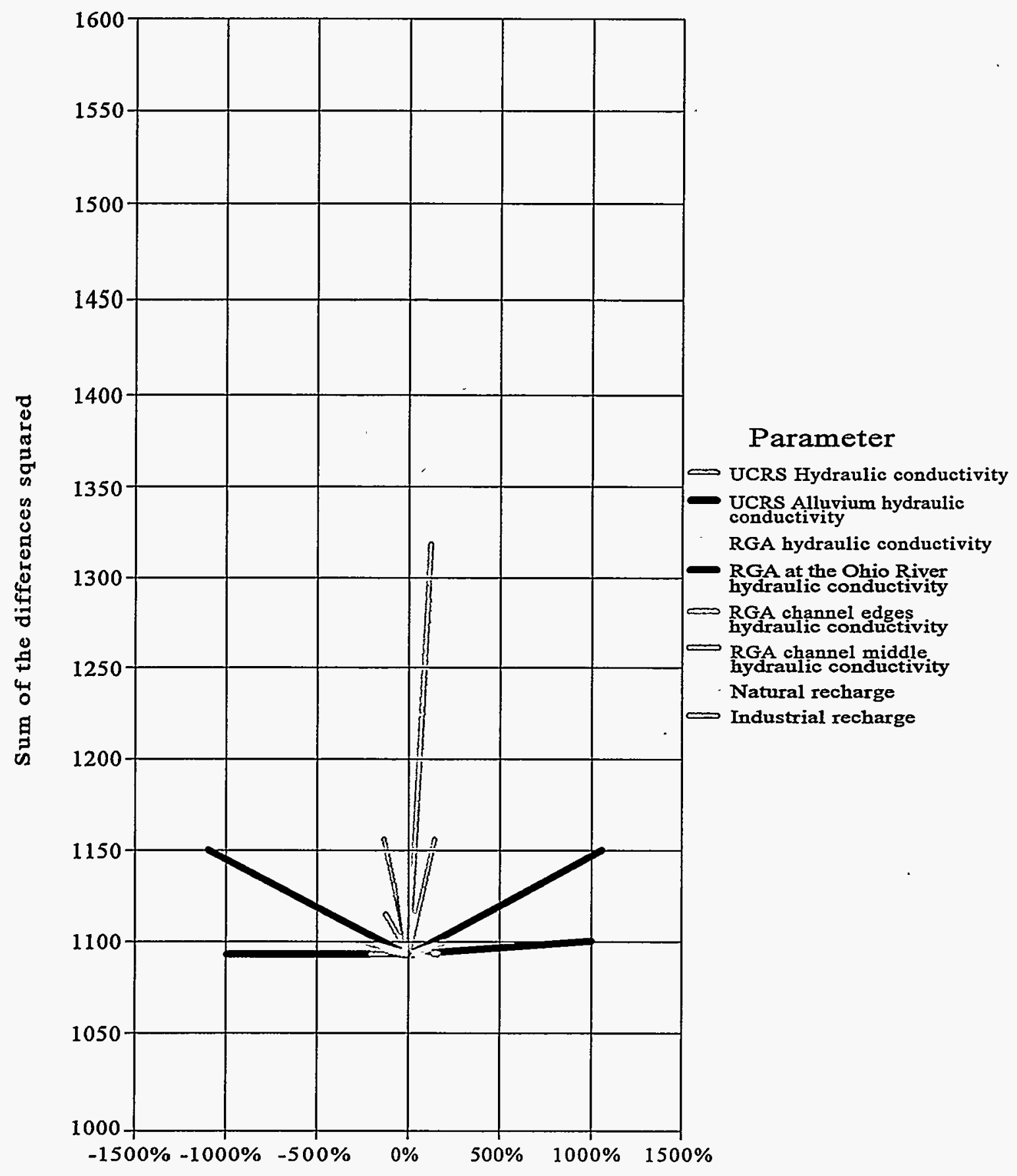

Change from calibrated value

Fig. 6.1. Sensitivity analysis. 
predict one it is necessary to know the other. Parameter estimation results demonstrated that the hydraulic conductivities of the RGA and the RGA channel edges were highly correlated to most of the other model input parameters and could not be estimated using parameter estimation techniques. Thus, reasonable values for these model input parameters were determined from available data and held constant during model calibration (Table 6.1).

\subsection{ESTIMATES OF AQUIFER PROPERTIES}

Parameter estimation was used to determine the best values for the remaining four sensitive, noncorrelated model input parameters (Table 6.1). Vertical hydraulic conductivities were not estimated because, while sensitive, small changes in hydraulic properties resulted in large changes in model error (the difference between target and model leads). Thus, parameter estimation could not improve upon the vertical hydraulic valves used in the model. The hydraulic conductivity of the UCRS was estimated to be $1.23 \mathrm{ft} / \mathrm{d}(4.3 \times$ $\left.10^{-4} \mathrm{~cm} / \mathrm{s}\right)$ with a $95 \%$ confidence interval between 0.88 to $1.71 \mathrm{ft} / \mathrm{d}\left(3.1 \times 10^{-4}\right.$ to $6.0 \times$ $10^{-4} \mathrm{~cm} / \mathrm{s}$ ). Many of the slug tests performed on UCRS wells measured hydraulic conductivity values in this range suggesting the model input value is reasonable (CH2M Hill 1992). For comparison, in the GeoTrans model the UCRS was assigned a hydraulic conductivity value of $1.0 \mathrm{ft} / \mathrm{d}\left(3.5 \times 10^{-4} \mathrm{~cm} / \mathrm{s}\right)$.

The hydraulic conductivity of the RGA at the Ohio River was estimated to be $21.4 \mathrm{ft} / \mathrm{d}$ $\left(7.6 \times 10^{-4} \mathrm{~cm} / \mathrm{s}\right)$ with a $95 \%$ confidence interval between 1.96 to $233.90 \mathrm{ft} / \mathrm{d}\left(6.9 \times 10^{-4}\right.$ to $8.3 \times 10^{-2} \mathrm{~cm} / \mathrm{s}$ ). Because the RGA hydraulic conductivity near the river has not been measured it is difficult to assess the reliability of the prediction. However, even considering the extremes of the confidence interval, the predicted value is less than the RGA hydraulic conductivity value used in the model, suggesting that there is indeed a difference in hydraulic conductivity between the two zones and it is appropriate to include a separate hydraulic conductivity zone within the model for the RGA adjacent to the Ohio River. Further evidence is provided in Clausen et al. (1995) which presented data showing an increase in gradient near the Ohio River, which could be associated with a reduction in hydraulic conductivity. Deposition of sediment within the Ohio River could have deposited silt along the RGA/river interface. For comparison, in the GeoTrans model, the RGA at the Ohio River was assigned a hydraulic conductivity value of $96.0 \mathrm{ft} / \mathrm{d}$ (3.4 $x$ $10^{-3} \mathrm{~cm} / \mathrm{s}$ ), which is within the parameter's predicted $95 \%$ confidence interval.

Recharge from precipitation (natural recharge) was estimated to be $8.76 \times 10^{-4} \mathrm{ft} / \mathrm{d}$ (3.84 in./year) with a $95 \%$ confidence interval of $7.31 \times 10^{-4} \mathrm{ft} / \mathrm{d}$ to $1.02 \times 10^{-3} \mathrm{ft} / \mathrm{d}$ (3.02 in./year to 4.47 in./year). Previous modeling studies had estimated recharge from precipitation to be $1.07 \times 10^{-3} \mathrm{ft} / \mathrm{d}$ (4.7 in./year) (McConnell 1992; GeoTrans 1992). However, previous modeling efforts lumped anthropogenic and natural recharge together 
as one input parameter. Although never directly measured, anthropogenic recharge is expected to be greater than natural recharge at PGDP (U.S. DOE 1996). Thus, a recharge value that combines anthropogenic and natural recharge is expected to be greater than one representing natural recharge alone.

Parameter estimation predicted the recharge rate from the 001 Outfall Ditch to be $2.43 \times$ $10^{-2} \mathrm{ft} / \mathrm{d}$ (106.4 in./year) with a $95 \%$ confidence interval of $1.94 \times 10^{-2} \mathrm{ft} / \mathrm{d}$ to $2.91 \times 10^{-2}$ $\mathrm{ft} / \mathrm{d}$ (84.9 in./year to $127.4 \mathrm{in} . /$ year). Average flow in the 001 Outfall ditch during August 1991, the time period against which the model was calibrated, was $1.4 \mathrm{Mgd}$. The predicted recharge rate from the 001 Outfall represents approximately $25 \%$ of the $1.4 \mathrm{Mgd}$. Assuming a flow length of $5000 \mathrm{ft}$ before leaving plant property, to maintain the model predicted recharge rate, the ditch would need to leak at a rate of $4.86 \times 10^{-2} \mathrm{gal} / \mathrm{min}$ per linear foot. Given this minimal leakage rate, the predicted recharge rate from the 001 Outfall ditch is reasonable.

\subsection{PREDICTED WATER LEVELS}

Water-level calibration targets as well as calibration results for the overall model domain are listed in Table 6.2. Thirty targets are in the UCRS (model layer 1) and 45 targets are in the RGA (model layer 2). As expected, the match between layer 2 target and model water levels was better than the match between layer 1 target and model water levels. Model predicted water levels represent the water level at the center of a model node. Few, if any, of the wells from which target water levels were obtained are screened across elevations corresponding to the middle of the model nodes. The impact of screen elevation on being able to match target water levels is far greater in the UCRS relative to the RGA. Groundwater flow in the RGA is primarily horizontal (U.S. DOE 1996; Clausen et al. 1995; Clausen et al. 1992), meaning there is not much change vertically in water-level elevations from the top to the bottom of the RGA. Thus, essentially the same water level will be recorded regardless of where a well is screened vertically in the RGA. A strong vertical flow component is present in the UCRS as evidenced by near unity vertical hydraulic gradients (U.S. DOE 1996). A unity gradient means that every foot elevation change produces a foot change in water-level elevation. Consequently, water levels from wells screened at the top or bottom of the UCRS will be significantly different from wells screened at the middle of the UCRS, which corresponds to the model predicted water level.

The calibrated model was also evaluated using lump sum statistics such as the residual mean, residual standard deviation, sum of the differences squared, and absolute residual mean (Table 6.3). Lump sum statistics represent model calibration error as a single number. A perfectly calibrated model will produce a lump sum statistic of zero. 
Table 6.3. Lump sum calibration statistics

\begin{tabular}{|l|c|c|c|}
\hline \multicolumn{1}{|c|}{ Statistic } & All & Layer 1 & Layer 2 \\
\hline \hline Residual Mean & -1.25 & -1.65 & -0.98 \\
\hline Residual Standard Deviation & 3.60 & 5.48 & 1.24 \\
\hline Sum of the Differences Squared & 1090 & 982 & 108 \\
\hline Absolute Residual Mean & 2.50 & 4.30 & 1.29 \\
\hline
\end{tabular}

Source of statistical formulas: Rumbaugh, J. O., and D. B. Rumbaugh. 1996. Guide to Using Groundwater Vistas. Environmental Simulations, Inc., Herndon, VA. 
The fact that all the lump sum statistics, with the exception of the sum of the differences squared (which squares and sums the target and model differences), are near zero suggests that the calibration of the model is good. For comparison the sum of the sum of the differences squared, residual mean, and residual standard deviation for the GeoTrans model were $1387.0,0.878$, and 3.35 , respectively.

The model predicted UCRS and RGA potentiometric surfaces are similar to the UCRS and RGA target potentiometric surfaces (Figs. 6.2 through 6.5). Both the model and target UCRS potentiometric surface show a radial pattern surrounding a potentiometric high located over the northwest quadrant of the plant surrounded by a radial decreasing potentiometric surface. The similarities in the model and target potentiometric surfaces suggest that the calibration of the model is good.

Figure 6.6 is a plot of model vs target water levels. For a perfect calibration, the model and target water levels would be equal, and all the data points would lie on the $45^{\circ}$ line. The data points, representing model and target water-level comparisons, cluster tightly around the $45^{\circ}$ line, indicating that the calibration of the model is good.

\subsection{PREDICTED PLUME FLOW PATHS}

Dense non-aqueous phase liquid (DNAPL), primarily TCE, is speculated to be present at both the C-400 and Northwest Corner source areas (Clausen et al. 1995). Typically, most DNAPL is found at the base of a flow system, which at the PGDP would be the RGA, with minor amounts residing in the overlying strata, which at the PGDP would be the UCRS, as residual ganglia.

Figure 6.7 shows the model-predicted flow paths from the C-400 Building and Northwest corner source areas. The flow paths were determined using particle tracking. Particle tracking allows particles placed in the model-generated flow domain to move in a series of small steps dictated by the hydraulic gradients. Connecting the location of an individual particle for each time step results in a particle trace that corresponds to a flow path. All of the particles originating in the RGA from the C-400 Building and Northwest Corner source areas, where most of the DNAPL is expected to be located, follow the general path of the Northwest plume suggesting that the model reasonably simulates the flow field. However, in the immediate vicinity of the two source areas the plume path could not be exactly replicated. Datá collected by Clausen et al. (1995) suggests that the plume originating from the $\mathrm{C}-400$ Building intersects the plume originating from the Northwest Corner source area. Particle traces from the $\mathrm{C}-400$ Building pass several hundred feet to the east of the Northwest Corner source area. 


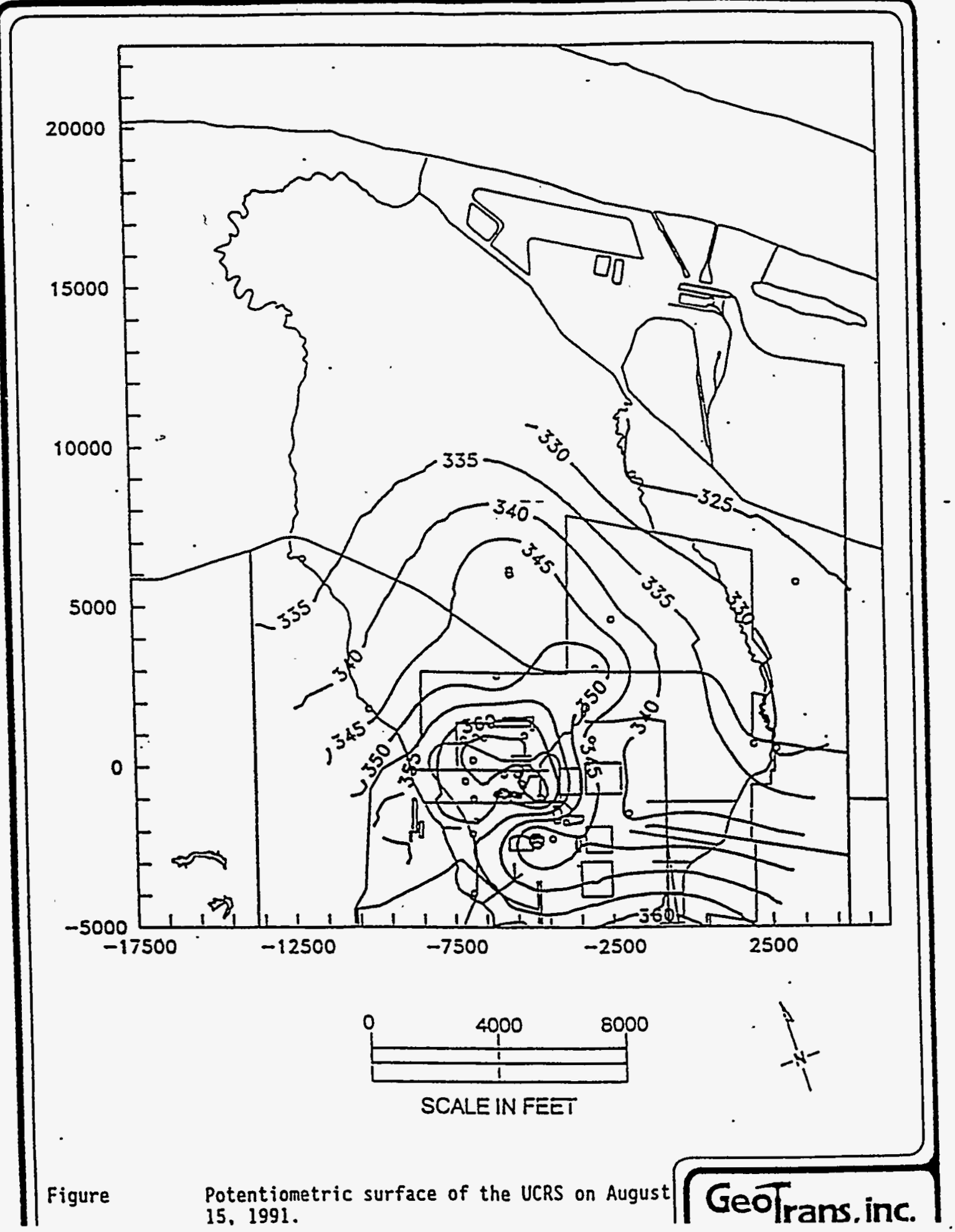

Fig. 6.2. Potentiometric surface of the UCRS on August 15, 1991. 


\section{6-11}

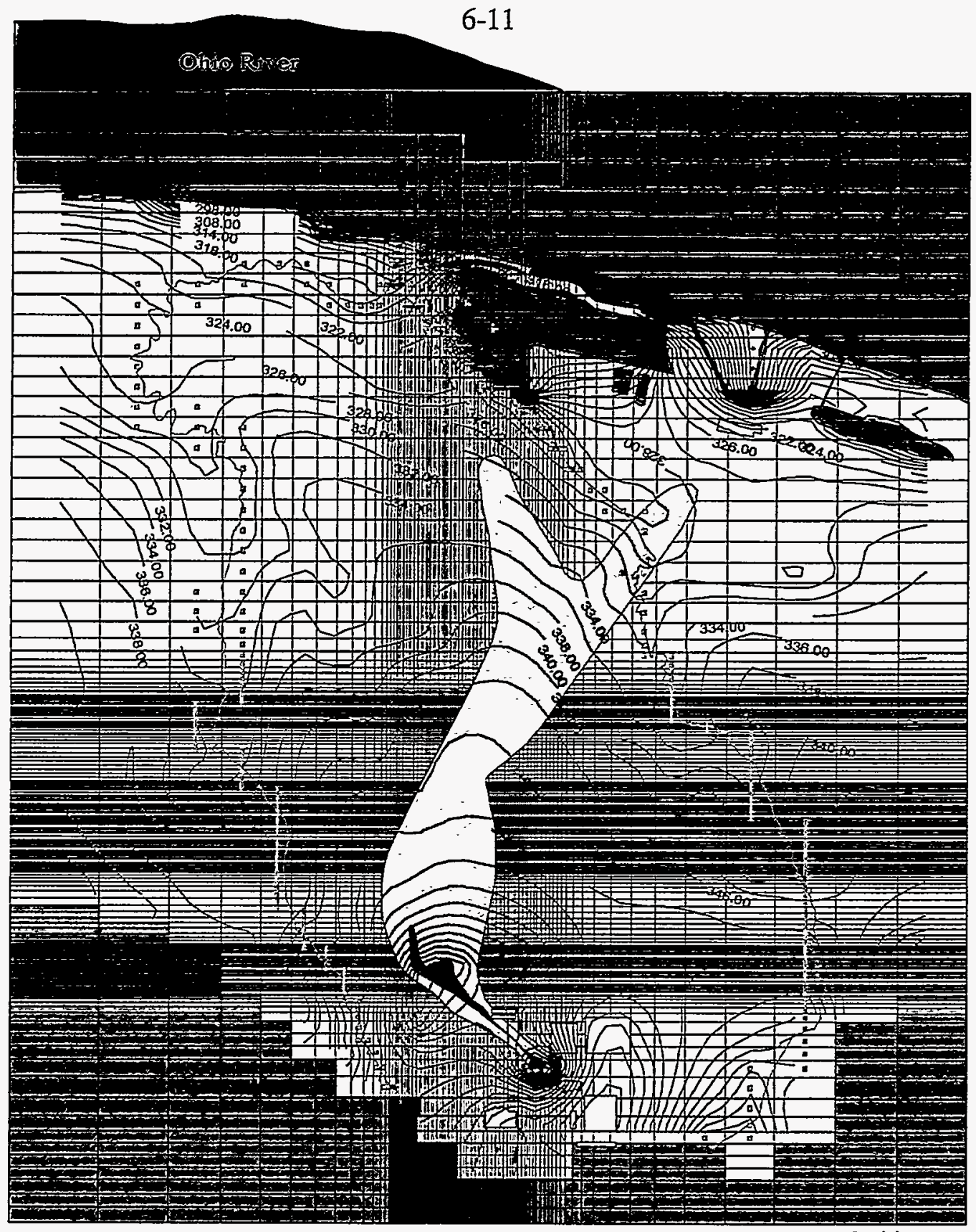

Paducah Gaseous Diffusion Plant

Lleatwir Paducah, Kentucky

Legend

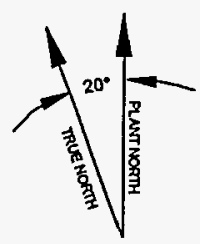

$\square$ VOC concentrations, > $10 \mathrm{ug} / 1$
VOC concentrations, > 1,000 ug/l
$\sim$ Potentiometric surface, ft msl
$\square$ Rivers and streams
Buildings
No Flow Cells
River cells
Constant head boundaries

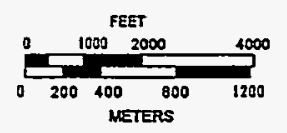

Fig. 6.3. Model predicted UCRS potentiometric surface. 


\section{$6-12$}

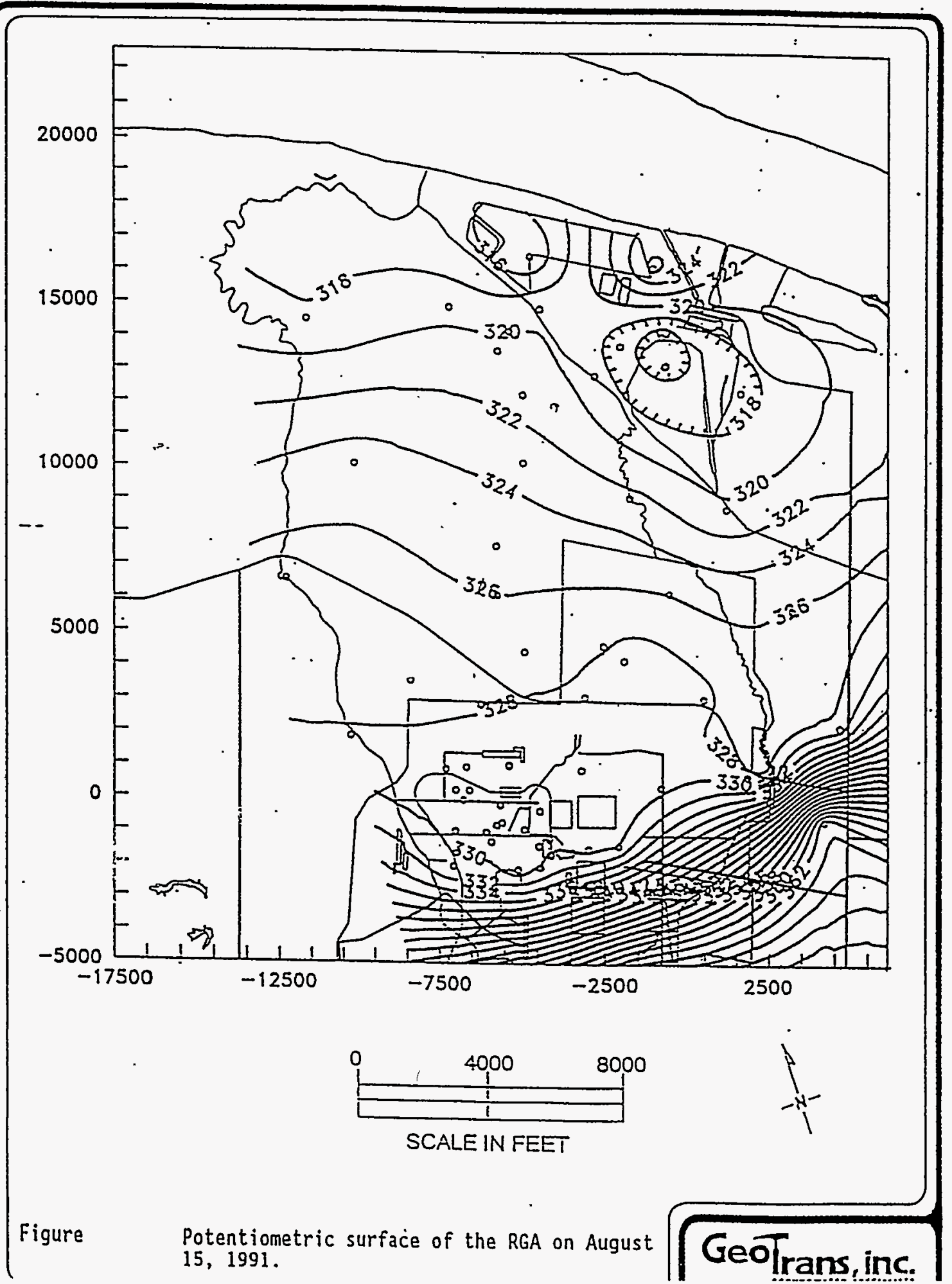

Fig. 6.4. Potentiometric surface of the RGA on August 15, 1991. 


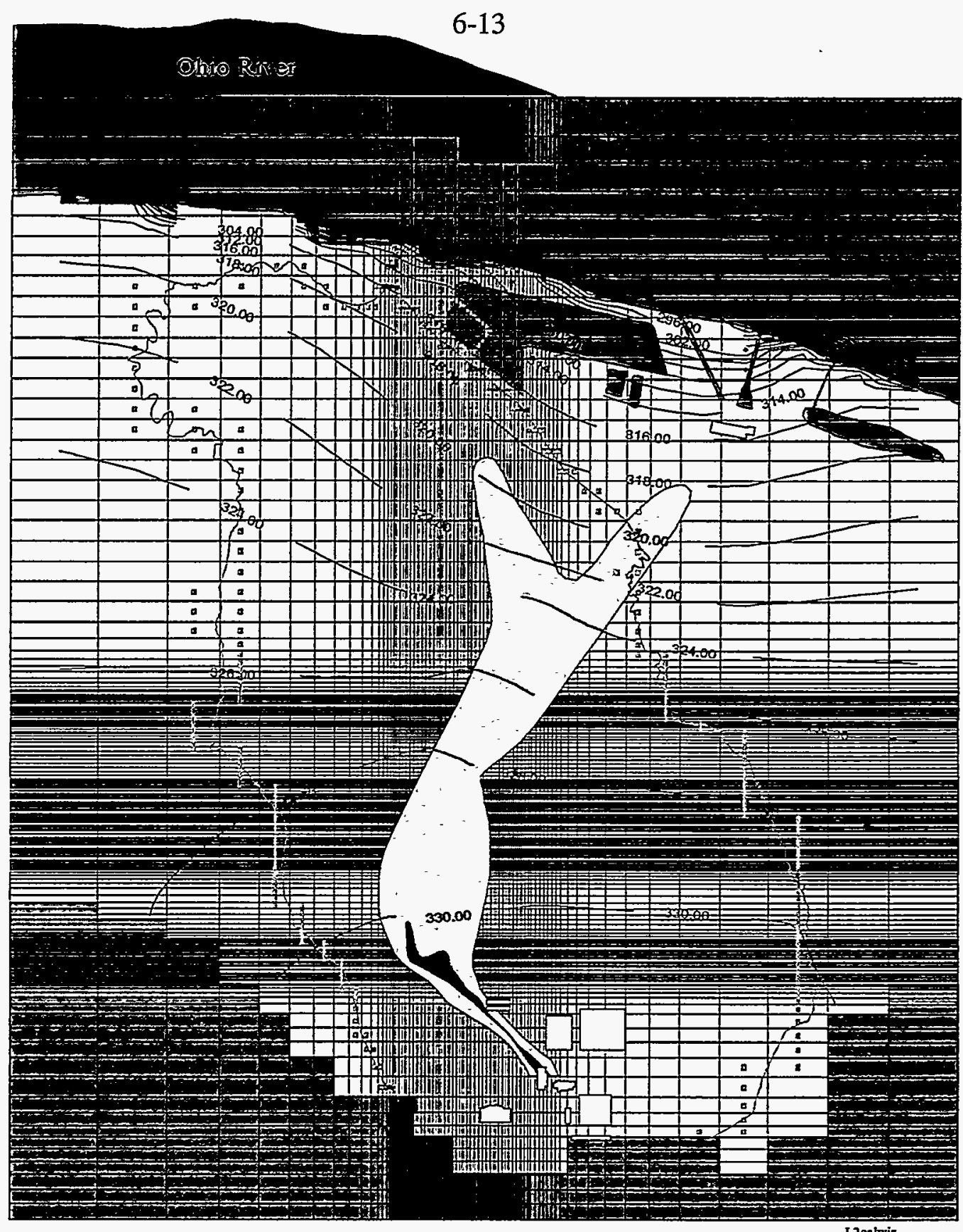

Paducah Gaseous Diffusion Plant

L2ealwir Paducah, Kentucky

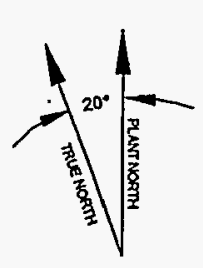

Legend

$\square$ VOC concentrations, > $10 \mathrm{ug} / 1$
VOC concentrations, > 1,000 ug/1
Potentiometric surface, ft msl
Rivers and streams
Buildings
$\odot \quad$ No Flow Cells
River cells
Constant head boundaries

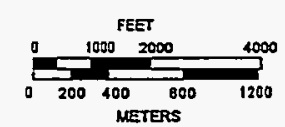

METERS 


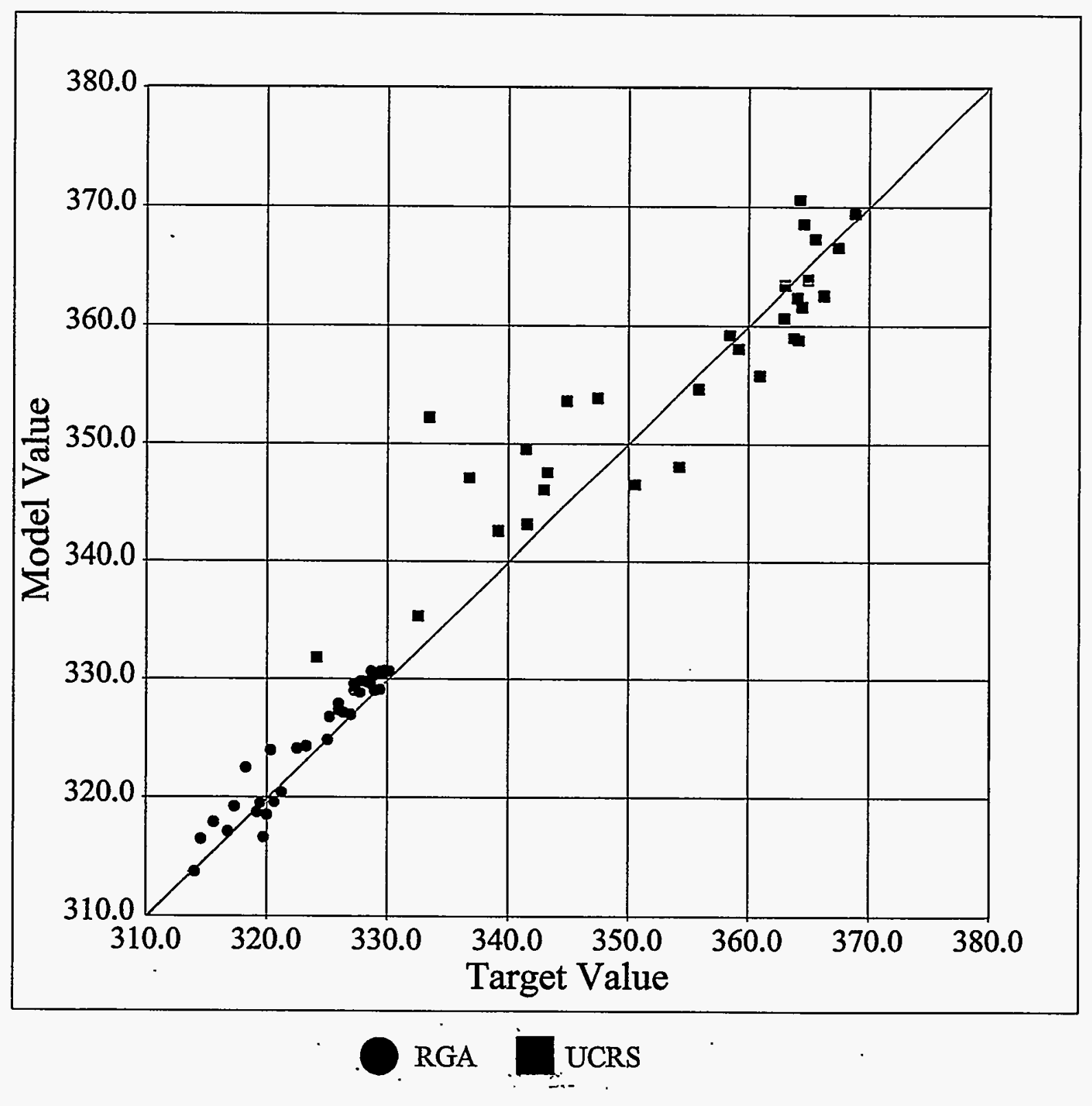

Fig. 6.6. Plot of model vs target water levels. 


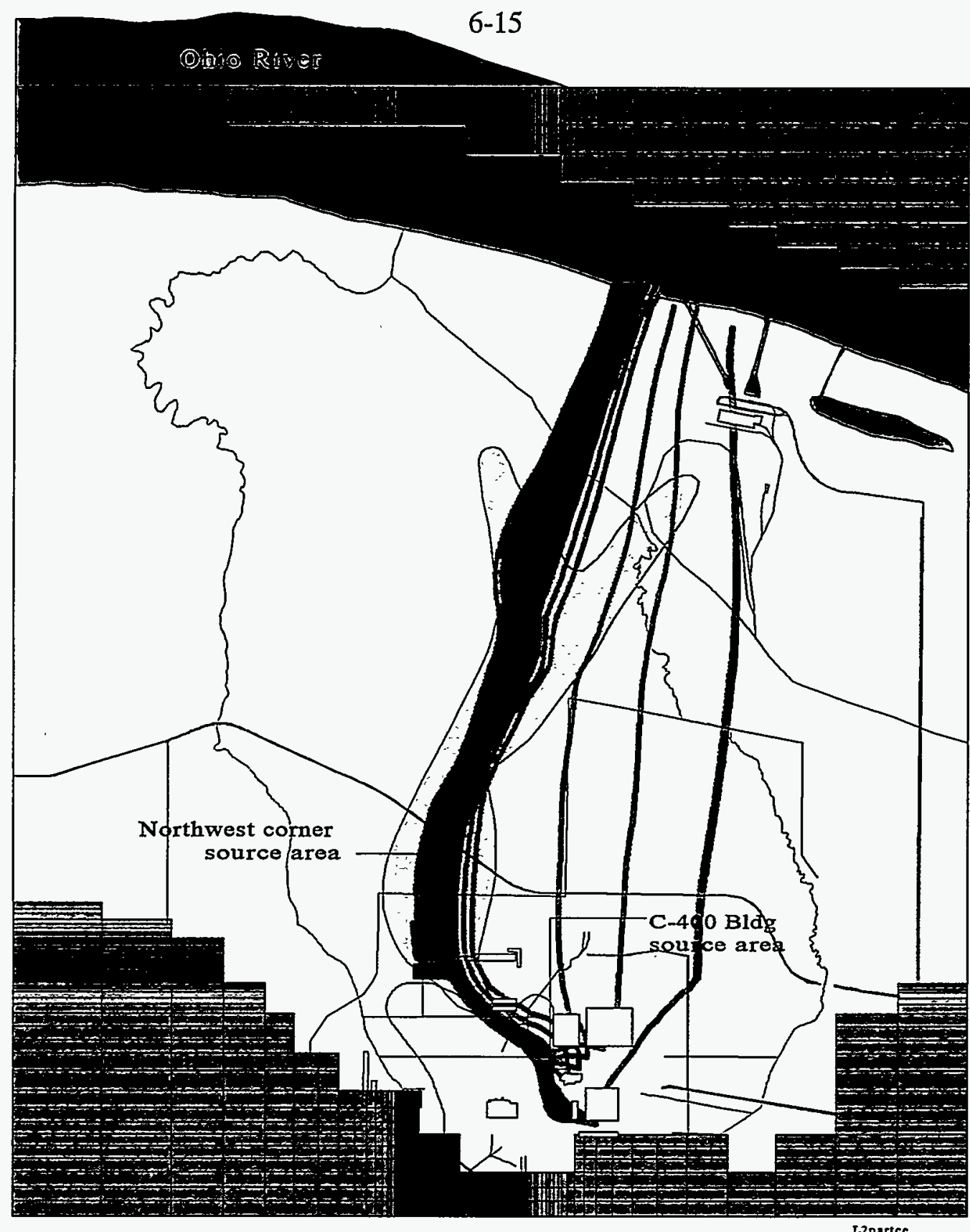

Paducah Gaseous Diffusion Plant Paducah, Kentucky

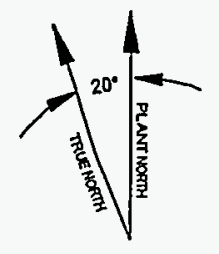

Legend

$\square$ VOC concentrations, $>10 \mathrm{ug} / 1$

- VOC concentrations, $>1,000 \mathrm{ug} / 1$

Particle traces

حivers and streams

$\square$ Buildings

No Flow Cells

Source areas

Fig. 6.7. Particle traces from source areas to the Ohio River. 
Interestingly, a few of the particles originating in the UCRS in the vicinity of the C-400 Building, where residual DNAPL ganglia are likely to be found, flow east of the main plume in the RGA to the Ohio River. Low levels of volatile organic compound (VOC) contamination have been detected in RGA wells in the northeast portion of the PGDP suggesting that these flow paths are reasonable.

The eastern most contaminant flow path is represented by a concentration of particle traces (Fig. 6.7). It is likely that the flow paths of these particle traces are influenced by the no-flow boundary along the east side of the model domain. If the model domain were extended further to the east, these particle traces might follow the path of the Northeast plume. Thus, based on this model, it is possible that the C-400 Building source contributes to both the Northwest and Northeast plumes.

Contaminant concentrations within the two plumes support this hypothesis. Contaminant concentrations in the Northeast plume are less, relative to contaminant concentrations in the Northwest plume. Modeling shows that contamination located in the RGA under the C-400 Building follows the path of the Northwest plume. Conversely, contamination located in the UCRS under the C-400 Building follows the path of the Northeast plume. DNAPL, specifically. TCE, is the source of the C-400 Building contamination. Based on expected DNAPL distribution patterns most of the free phase TCE should be located in the RGA. A smaller amount of free phase TCE should be located in the UCRS. Thus, while not conclusive, the modeling results suggests that the C-400 Building source contributes to both the Northwest and Northeast plumes. Other sources may also contribute to both plumes.

Of interest, modeling also showed that if anthropogenic recharge from the 001 Outfall ditch was removed from the model, particles originating in both the UCRS and RGA followed the Northwest plume. If anthropogenic recharge from the 001 Outfall ditch was increased, a greater percentage of the UCRS particles followed flow paths east of the Northwest plume. While not conclusive, these results suggest that anthropogenic recharge from the 001 Outfall ditch influences the Northeast plume.

It is important to note that the WAG 6 investigation identified other potential sources of anthropogenic recharge. While unquantified, it is likely that these sources in addition to the 001 Outfall ditch influence contaminant migration at the site. 


\section{$7-1 \quad$}

\subsection{PREDICTIVE SIMULATIONS}

Three predictive simulations were performed to determine the capture zones of the Northwest Plume interceptor systems north and south well fields for various pumping scenarios. Each well field consists of two wells. The first simulation determined the capture zones for the wells operating under the current pumping scenario of $50 \mathrm{gal} / \mathrm{min}$ $\left(9625 \mathrm{ft}^{3} / \mathrm{d}\right.$ ) well. A second simulation determined the optimum pumping rates for the four wells, defined as the minimum rates needed to contain contamination emanating from source areas. The final simulation determined the optimal pumping rates required to contain contamination emanating from the two source areas using only the two wells in the south well field. All simulations assumed UCRS and RGA porosities of 0.40 and 0.25, respectively (Hughes et al. 1996 and McConnell 1992).

\subsection{CURRENT PUMPING SCENARIO}

Because of treatment system limitations, the combined pumping rate for both the north and south well fields presently can not exceed $200 \mathrm{gal} / \mathrm{min}\left(38,500 \mathrm{ft}^{3} / \mathrm{d}\right)$. Pumping currently is divided evenly between the four wells at approximately $50 \mathrm{gal} / \mathrm{min}(9625$ $\mathrm{ft}^{3} / \mathrm{d}$ ) per well. Figure 7.1 shows the well field capture zones for interceptor system operating at maximum treatment capacity. Contamination emanating from the Northwest source area is contained by the south well field. The north well field capture zone contains groundwater contamination east of the C- 400 Building. The C- 400 Building, a known source area, lies between the two capture zones. Thus, as modeled, contamination emanating from the $\mathrm{C}-400$ Building source eludes capture.

This analysis contradicts a previous study that predicted the plume and source areas would be contained at pumping rates of $50 \mathrm{gal} / \mathrm{min}\left(9625 \mathrm{ft}^{3} / \mathrm{d}\right)$ per well (Phillips et al. 1996). The previous study assumed RGA hydraulic conductivities of approximately 1000 and $2500 \mathrm{ft} / \mathrm{d}(0.35$ to $0.88 \mathrm{~cm} / \mathrm{s})$ for the south and north well fields, respectively. A pumping test conducted at the south and north well fields determined hydraulic conductivity to be approximately 1200 and $5000 \mathrm{ft} / \mathrm{d}(0.42$ and $1.8 \mathrm{~cm} / \mathrm{s})$, respectively, in the vicinity of the well fields. Capture zone width is inversely proportional to hydraulic conductivity. Thus, based solely on the pumping test hydraulic conductivity data, for the same pumping rates, the capture zone widths for the north well field is expected to be about twice as small as those predicted by Phillips (1996).

Douthitt and Phillips (1994) predicted capture zone widths of $1200 \mathrm{ft}$ for both the north and south wells fields when operated at $100 \mathrm{gal} / \mathrm{min}$ per well field. However, the measurement locations of the capture zone widths were not reported. This study's modeled north and south well field capture zones (measured parallel to the north PGDP perimeter fence) are approximately $500-\mathrm{ft}$ and $650-\mathrm{ft}$ wide, respectively. The plume hotspot 


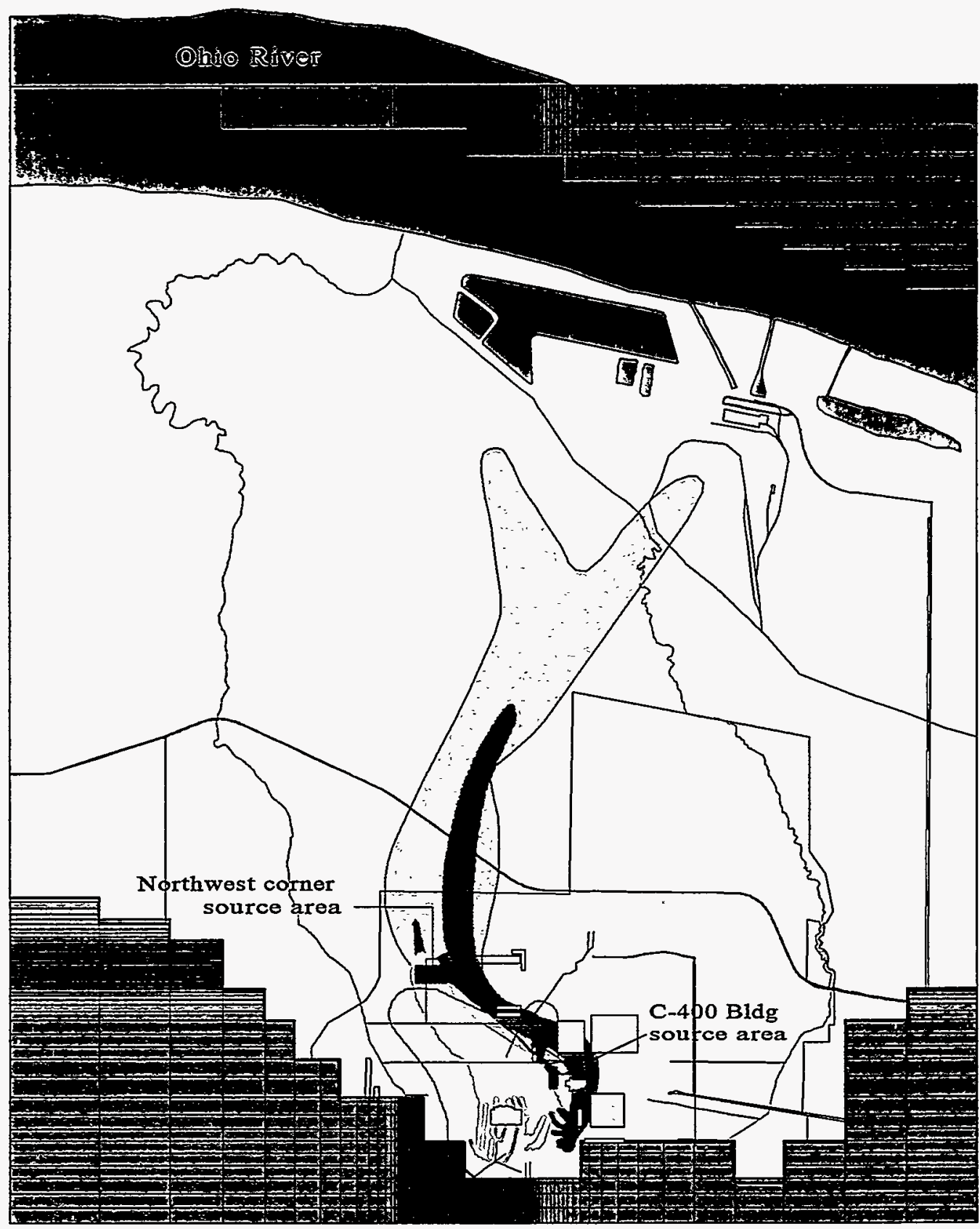

Paducah Gaseous Diffusion Plant Paducah, Kentucky

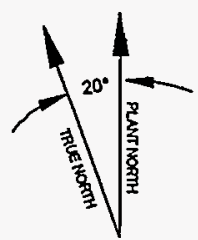

\section{Legend}

$\square$ VOC concentrations, $>10 \mathrm{ug} / 1$

VOC concentrations, $>1,000 \mathrm{ug} / 1$

Particle traces, north well field

- Particle traces, south well field

Rivers and streams

$\square$ Buildings

No Flow Cells

Source areas

Fig. 7.1. Capture zones for wells pumping at $50 \mathrm{gal} / \mathrm{min}$. 
(defined as TCE contributions greater than $1000 \mu \mathrm{g} / \mathrm{L}$ ) at the same location, is approximately 2000 -ft wide. Thus, as presently operated, the Northwest Plume interceptor system appears incapable of containing the plume hotspot.

\subsection{OPTIMUM PUMPING SCENARIO FOR THE NORTH AND SOUTH WELL FIELDS}

Optimum pumping rates for the wells in the north and south fields were determined to be $200 \mathrm{gal} / \mathrm{min}\left(38,500 \mathrm{ft}^{3} / \mathrm{d}\right)$ per well and $75 \mathrm{gal} / \mathrm{min}\left(14,438 \mathrm{ft}^{3} / \mathrm{d}\right)$ per well, respectively, for a combined pumping rate of $550 \mathrm{gal} / \mathrm{min}\left(105,875 \mathrm{ft}^{3} / \mathrm{d}\right)$. At these pumping rates both the C-400 Building and Northwest Corner source areas are within the south well field capture zone (Fig. 7.2). Maintaining both source areas within the south well field capture zone is important because, in response to pumping, plume concentrations may sufficiently decline such that the north well field is no longer necessary. The north well field capture zone surrounds the south well field capture zone providing additional source area containment. Portions of the plume outside the capture zones, having VOC contaminant concentrations up to $1,000 \mu \mathrm{g} / \mathrm{L}$, will ultimately discharge to the Ohio River. Because the source areas are contained, contaminated groundwater outside the capture zones will eventually be replaced with clean groundwater and contaminant concentrations will drop.

The optimum pumping rates required to contain the plume were determined using the calibrated model input parameters which individually represent the best value for a range of parameter values. For example, consider the hydraulic conductivity of the RGA. A value of $425 \mathrm{ft} / \mathrm{d}(0.15 \mathrm{~cm} / \mathrm{s})$ was used in the model to represent hydraulic conductivities that have been determined from aquifer tests to range from approximately 100 to $800 \mathrm{ft} / \mathrm{d}$ $\left(3.5 \times 10^{-2}\right.$ to $\left.0.28 \mathrm{~cm} / \mathrm{s}\right)$. For robustness, the optimized pumping scheme should contain the plume for all RGA hydraulic conductivity values within this range. In addition to the RGA hydraulic conductivity, the optimized pumping scheme should also contain the plume over the expected range of all other model input parameters.

Capture zone analysis was performed for all the minimum and maximum input parameters listed in Table 7.1. Where possible, the extremes of the $95 \%$ confidence limits (as predicted using parameter optimization) were used as minimum and maximum model input values. For other input parameters, the range of measured values was used to determine minimum and maximum model input values. For the UCRS alluvium hydraulic conductivity (which has never been measured) the minimum and maximum input values were assumed to be an order of magnitude less and greater than the model input parameter. During a simulation, all input parameters other than the parameter of interest were held constant at their calibrated values. Complete capture was achieved for all simulations. This demonstrates that the optimum pumping rates are robust for a wide range of possible parameter values. 


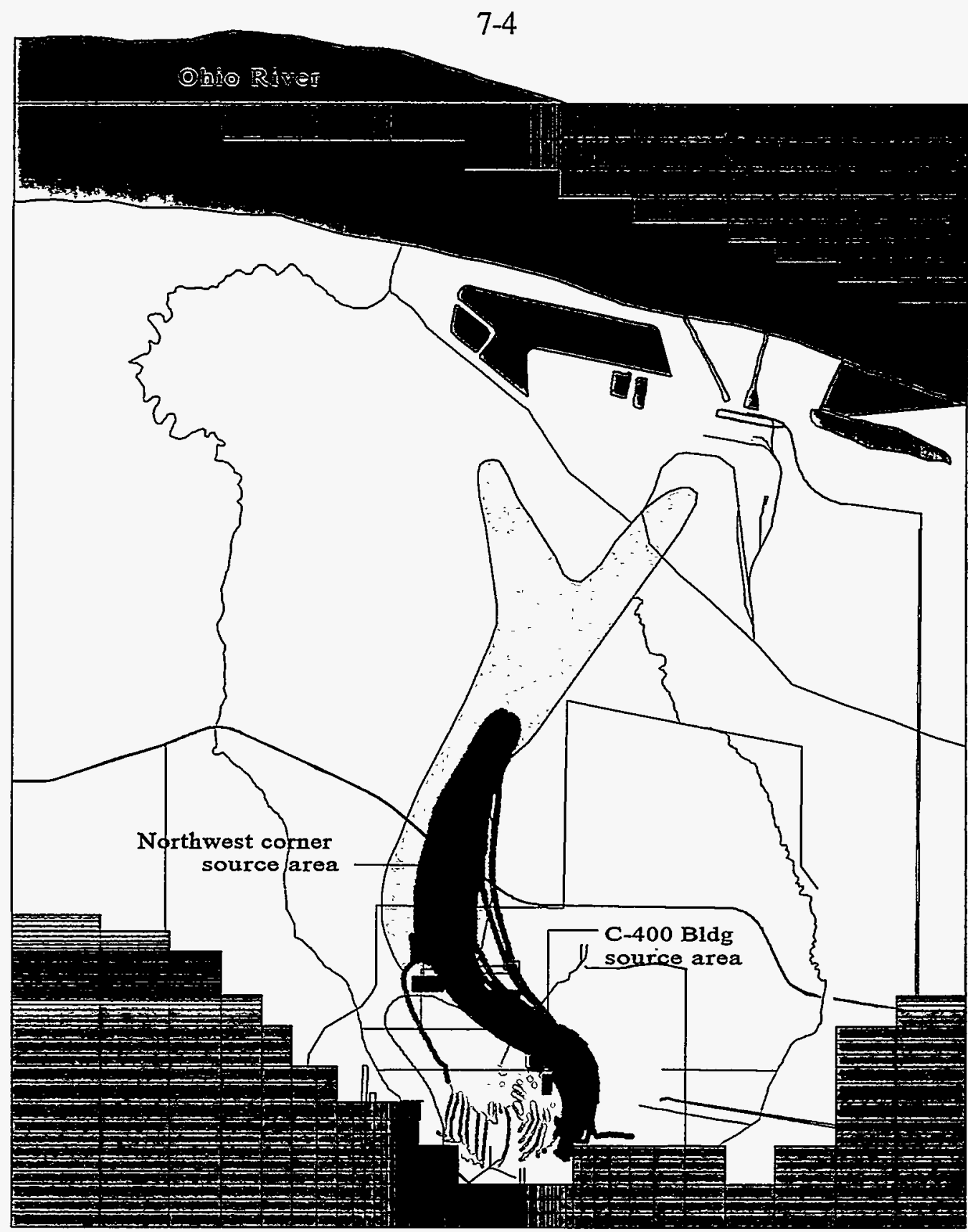

OPT

Paducah Gaseous Diffusion Plant

Paducah, Kentucky

Legend

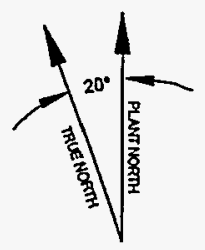

$\Xi$ VOC concentrations, $>10 \mathrm{ug} / 1$

VOC concentrations, $>1,000 \mathrm{ug} / 1$

- Particle traces, north well field

$\sim$ Particle traces, south well field

- Rivers and streams

$\square$ Buildings

No Flow Cells

Source areas

Fig. 7.2. Capture zones for optimum pumping rates. 
Table 7.1. Model calibrated, minimum, and maximum input parameter values, $\mathrm{ft} / \mathrm{d}$

\begin{tabular}{|l|r|r|r|}
\hline \hline \multicolumn{1}{|c|}{ Parameter } & \multicolumn{1}{c|}{$\begin{array}{c}\text { Calibrated } \\
\text { value }\end{array}$} & \multicolumn{1}{c|}{$\begin{array}{c}\text { Minimum } \\
\text { value }\end{array}$} & $\begin{array}{c}\text { Maximum } \\
\text { value }\end{array}$ \\
\hline \hline UCRS hydraulic conductivity & 1.23 & 0.88 & 1.71 \\
\hline $\begin{array}{l}\text { UCRS alluvium hydraulic } \\
\text { conductivity }\end{array}$ & 2.50 & 0.25 & 25.00 \\
\hline RGA hydraulic conductivity & 425.00 & 53.00 & 1475.00 \\
\hline $\begin{array}{l}\text { RGA at the Ohio River hydraulic } \\
\text { conductivity }\end{array}$ & 21.40 & 1.96 & 233.90 \\
\hline $\begin{array}{l}\text { RGA channel edges hydraulic } \\
\text { conductivity }\end{array}$ & 2500.00 & 1000.00 & 5000.00 \\
\hline $\begin{array}{l}\text { RGA channel middle hydraulic } \\
\text { conductivity }\end{array}$ & 5000.00 & 2500.00 & 8000.00 \\
\hline Natural recharge & $8.76 \times 10^{-4}$ & $7.31 \times 10^{-4}$ & $1.02 \times 10^{-3}$ \\
\hline Industrial recharge & $2.43 \times 10^{-2}$ & $1.94 \times 10^{-2}$ & $2.91 \times 10^{-2}$ \\
\hline
\end{tabular}


Particle tracking suggests that approximately ten years will be required to remove one pore volume of contaminated groundwater from the aquifer. A pore volume is defined here as the volume of contaminated groundwater located within the capture zones between the well fields and source areas. Time to remove one pore volume for both well fields is similar primarily because of variability in hydraulic conductivity. The south well field capture zone extends into the lower hydraulic conductivity portions ( $425 \mathrm{ft} / \mathrm{d}$ $(0.15 \mathrm{~cm} / \mathrm{s})$ of the RGA. In contrast, the north well field capture zone is confined primarily within the highly transmissive zone where hydraulic conductivities are believed to be between 2500 and $5000 \mathrm{ft} / \mathrm{d}(0.88$ to $1.8 \mathrm{~cm} / \mathrm{s})$. All else being equal, the higher the hydraulic conductivity the faster the capture zone development. Thus, even though the north well field is further from the source areas, the time required to remove one pore volume is similar to the south well field. Pore volume removal rates should not be equated with the time required to remediate to current drinking water standards. Numerous studies suggest that when DNAPL is present tens to hundreds of pore volumes will need to be removed to achieve drinking water standards (National Research Council 1994).

Particle tracking also suggests that approximately eleven years will be required for all groundwater contamination located outside capture zones to reach the Ohio River. Again, this time should not be equated with the time required to achieve drinking water standards. Because of matrix diffusion, it will take more than 11 years to achieve drinking water standards outside the well field capture zones (National Research Council 1994).

\subsection{OPTIMUM PUMPING SCENARIO FOR THE SOUTH WELL FIELD}

Because the previous simulation demonstrated that both source areas can be contained by the south well field, in the future it may be desirable to turn off the north well field and rely solely on the south well field for containment. Optimum south well field pumping rates were determined to be $75 \mathrm{gal} / \mathrm{min}$ per well for a combined pumping rate of $150 \mathrm{gal} /$ $\mathrm{min}$. At these pumping rates, both the C-400 Building and Northwest source areas are within the south well field capture zone (Fig. 7.3). Particle tracking demonstrated that ten years will be required to remove one pore volume of contaminated water from the aquifer. Similar to the previous simulation, complete capture was achieved for the full range of parameter values listed in Table 7.1. 


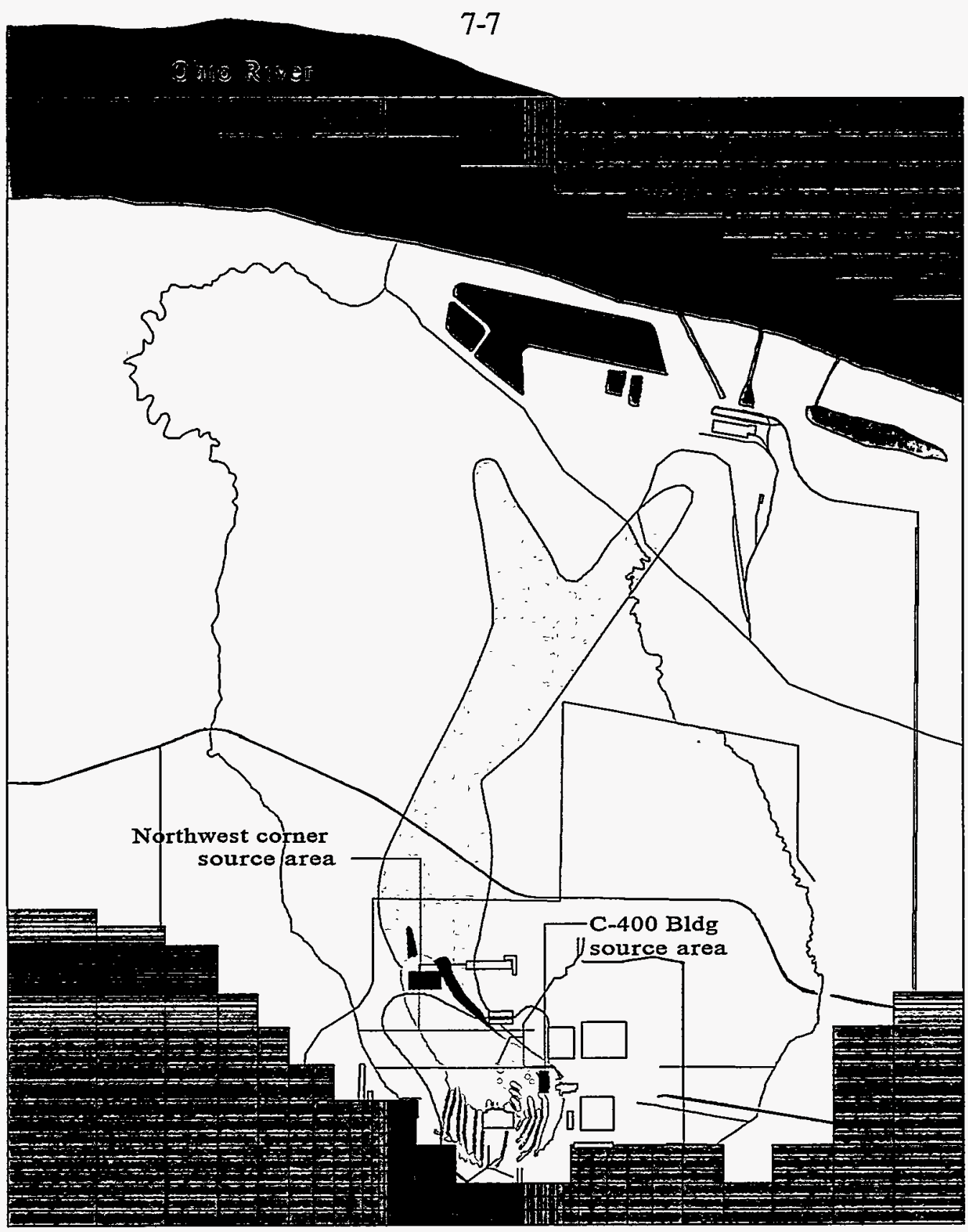

Paducah Gaseous Diffusion Plant

optsf Paducah, Kentucky

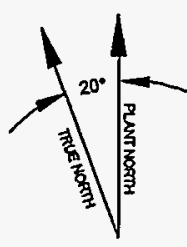

Legend
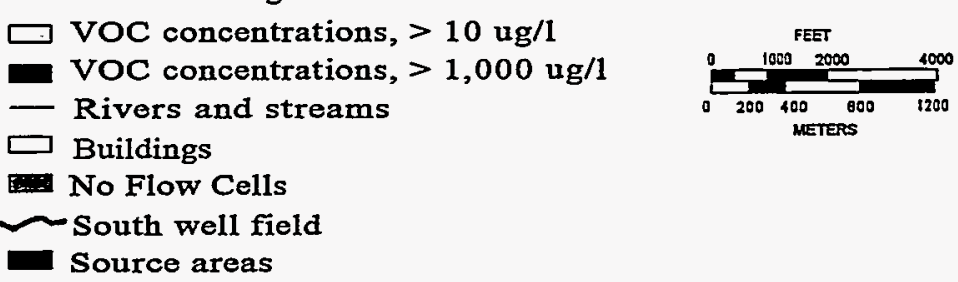

Fig. 7.3. Capture zone for south well field pumping at optimum rates. 


\subsection{MODEL EVALUATION}

Calibration results demonstrate that the model adequately simulates the groundwater flow regime at the PGDP and can be used to predict the capture zones of the north and south well fields. However, the overall mass balance error for the model (the difference between water entering and leaving the model domain) was $10 \%$. In some portions of the model, the mass balance error approached $50 \%$. Mass balance errors for most models are under $1 \%$. Although not reported, the original GeoTrans model suffered from the same mass balance problem, which is related to the large head differences between model layers 1 and 2, representing the UCRS and RGA, respectively. 


\subsection{CONCLUSIONS}

Results of the interceptor system evaluation support the following conclusions :

- As presently operated, the interceptor system is marginally effective in containing the Northwest plume hotspot. This conclusion contradicts a previous study which suggested that containment was possible at $50 \mathrm{gal} / \mathrm{min} /$ well (Phillips 1996). The difference in conclusions can be attributed to a high hydraulic conductivity zone in the vicinity of the two well fields.

- Pumping rates of $75 \mathrm{gal} / \mathrm{min}$ per well in the south well field and $200 \mathrm{gal} / \mathrm{min}$ per well in the north well field are necessary to contain the plume.

- The south well field alone is capable of containing contamination emanating from the C-400 Building and Northwest Corner source areas at a well field pumping rate of $150 \mathrm{gal} / \mathrm{min}$.

- Approximately ten years will be required to remove one pore volume of contaminated groundwater from the aquifer. A pore volume is defined as the volume of contaminated groundwater located within the capture zone between the well field and source area.

- Model results may only be valid for periods of low Ohio River stage and may not adequately portray actual capture zones during periods of high river stage during which RGA groundwater flow is primarily eastward. 


\subsection{RECOMMENDATIONS}

- Groundwater modeling suggests that anthropogenic recharge associated with the 001 Outfall ditch could be contributary to the development of the Northeast plume. A study should be conducted to characterize the interaction of the 001 Outfall and other ditches with shallow groundwater. Additionally, predictive modeling should be undertaken to develop a better understanding of how changes in ditch discharge rates affect contaminant migration at the site.

- To alleviate potential mass balance problems future groundwater models should simulate the UCRS with multiple model layers rather than with a single model layer.

- The model simulated the PGDP flow system as a steady-state flow system. In reality the flow system is transient and responds to precipitation events, fluctuating leakage rates from ditches and underground utilities and changes in Ohio River stage. Investigations should be undertaken to determine if these perturbations cause significant temporal changes in the PGDP flow field. If any of these perturbations prove to be significant then a transient flow model that includes these temporal perturbations should be constructed and used to evaluate the interceptor system.

- Efforts should be made to better characterize the interaction of the Terrace Gravels and the PGDP groundwater flow system. Additionally, predictive modeling should be undertaken to develop an understanding of how temporal changes in Terrace Gravel discharge rates affect contaminant migration at the site.

- In addition to anthropogenic recharge, the presence of a.zone of higher RGA hydraulic conductivity zone between the two well fields greatly influenced model particle paths. Without the combination of anthropogenic recharge and the higher hydraulic conductivity zone, particle traces did not follow the path of the Northwest Plume. Future modeling should focus on evaluating the effects of heterogeneity, such as the higher hydraulic conductivity zone, on groundwater flow and plume configuration.

- The eastern no-flow model boundary influences the migration paths of particles migrating from C-400 to the northeast. Better simulation of the flow system and portrayal of the Northeast Plume configuration may be possible by expanding the eastern no-flow model boundary to the east.

- Although the McNairy Formation, as represented in the GeoTrans model, was determined to minimally influence groundwater flow and contaminant transport, future models should include the McNairy Formation so that the hydraulic relationship between it and the other hydrogeologic units can be better understood. 


\subsection{REFERENCES}

CH2M Hill. 1992. Results of the Site Investigation, Phase II. KY/SUG/13B-97777CP03/1991/1. CH2M Hill Southeast, Inc., Oak Ridge, Tennessee.

Clausen, J. L., J. L. Zutman, D. A. Pickering, and N. JD. Farrow. 1995. Final Report on Drive-Point Characterization of the Northwest Plume at the Paducah Gaseous Diffusion Plant, KY/ER-66, Martin Marietta Energy Systems, Inc., Paducah Gaseous Diffusion Plant, Paducah, Kentucky.

Clausen, J. L., J. W. Douthitt, K. R. R. Davis, and B. E. Phillips. 1992. Report of the Paducah Gaseous Diffusion Plant Groundwater Investigation Phase III, KY/E-150. Lockheed Martin Energy Systems, Kevil, Kentucky.

Davis, K. R. 1996. The McNairy Formation in the Area of the Paducah Gaseous Diffusion Plant. KY/EM-148.

Doherty, J., L. Brebber, and P. Whyte. 1994. PEST, Model-Independent Parameter Estimation. Water Mark Computing.

Douthitt, J. W. and B. E. Phillips. 1994. Model assisted design of a groundwater pump and treat system at the Paducah Gaseous Diffusion Plant. American Institute of Hydrology, in Toxic Substances in the Hydrologic Science, p. 346-365.

GeoTrans. 1993. Assessment of Containment Alternatives of the Northwest Plume, Paducah Gaseous Diffusion Plant, Project No. 6506-004, GeoTrans, Inc., Sterling, Virginia.

GeoTrans. 1992. Groundwater Modeling and Offsite Containment Evaluation at the Paducah Gaseous Diffusion Plant, Phase III: Optimization, Project No. 6506-003, GeoTrans, Inc., Sterling, Virginia.

Hughes, B. M., S. V. Ho, C. J. Athmer, P. W. Sheridan, S. H. Shoemaker, J. R. Larsen, J. L. Clausen, and J. L. Zutman. 1996. Development of an integrated in-situ remediation technology: Topical report for task \#11, evaluation of TCE contamination before and after the field experiment.

McConnell, C. L. 1992. A Steady State Computer Model of the C-404 Landfill Area in Clausen J. L., et al. 1992. Resource Conservation and Recovery Act Part B Permit Modification for Inclusion of C-404 Low-Level Radioactive/Hazardous Waste Landfill, KY/E-129, Martin Marietta Energy Systems, Inc., Paducah Gaseous Diffusion Plant. 
McDonald, M. G., and A. W. Harbaugh. 1988. A Modular Three-Dimensional Finite Difference Ground-Water Flow Model. Open-File Report 83-875. U.S. Geological Survey.

National Research Council. 1994. Alternatives of Ground Water Cleanup. National Academy Press, Washington, D.C.

Phillips, B. E. 1996. Aquifer Test Analysis of the Northwest Plume, Paducah Gaseous Diffusion Plant, Paducah, Kentucky, KY/EM-145. Environmental Management and Enrichment Facilities, Kevil, Kentucky.

Pollock, D. W. 1989. Documentation of Computer Programs to Compute and Display Pathlines Using Results from the U.S. Geological Survey Modular ThreeDimensional Finite-Difference Ground-Water Flow Model. Open-file Report 89381. U.S. Geological Survey.

Rumbaugh, J. O., and D. B. Rumbaugh. 1996. Guide to Using Groundwater Vistas. Environmental Simulations, Inc., Herndon, Virginia.

U.S. DOE. 1996. Phase I: Paducah Gaseous Diffusion Plant Waste Area Group6 Industrial Hydrogeologic Study. DOE/OR/07-1478\&D1. U.S. Department of Energy.

U.S. DOE. 1993. Record of Decision for Interim Remedial Action at the Northwest Plume, Paducah Gaseous Diffusion Plant, Paducah, Kentucky. DOE/OR/06$1143 \& D 4$. U.S. Department of Energy. 
APPENDIX A

REPORT COMMENTS AND RESPONSES 


\section{DESIGN REVIEW RECORD}

Project Title: Paducah Gaseous Diffusion Plant Northwest Plume Interceptor System Evaluation Date: 11/6/96 Job Title: Alan Laase and Jay Clausen

\begin{tabular}{|c|c|c|c|}
\hline $\begin{array}{l}\text { Item } \\
\text { No. }\end{array}$ & $\begin{array}{l}\text { Drawing or spec. } \\
\text { no. \& paragraph }\end{array}$ & Comments & $\begin{array}{c}\text { A-E } \\
\text { Action } \\
\end{array}$ \\
\hline 1 & $\begin{array}{l}\text { Drew Diefendorf } \\
\text { LMER } \\
\text { General Comment }\end{array}$ & $\begin{array}{l}\text { My comments on the report are based on the observation } \\
\text { that we continue to mold the conceptual hydrogeologic } \\
\text { model of the site to fit our arguments. The report clearly } \\
\text { supports my concern that: } \\
\text { 1. We have not adequately defined the recharge effects } \\
\text { from the terrace deposits and Bayou and Little Bayou } \\
\text { Creeks. } \\
\text { 2. The industrial hydrogeology, in particular, anthropo- } \\
\text { genic sources and sinks of groundwater have not been } \\
\text { adequately defined. } \\
\text { Both of these issues were noted as objectives for the Phase } \\
\text { While the modeling effort included potential effects from } \\
\text { the } 001 \text { Outfall, it did not include effects from other natural } \\
\text { and anthropogenic sources and sinks as outlined above. }\end{array}$ & $\begin{array}{l}\text { Agree, but models are supposed to be molded to } \\
\text { our conceptual model when there is a lack of } \\
\text { data. We agree recharge has not been adequately } \\
\text { defined at the site, however in the absence of } \\
\text { hard data assumptions were used in the model. } \\
\text { The objective of this model was to assess the } \\
\text { Northwest Plume capture zones with the avail- } \\
\text { able data, not to define recharge rates. The } \\
\text { current modeling effort utilized the assumptions } \\
\text { of hydraulic conductivity for the creeks assigned } \\
\text { by GeoTrans in } 1992 \text {. These assumptions were } \\
\text { agreed upon by LMES during modeling } \\
\text { development by GeoTrans and appear reasonable } \\
\text { in the absence of real data. Modeling is an itera- } \\
\text { tive process where one builds upon the assump- } \\
\text { tions as new data is collected until a point is } \\
\text { reached that additional data won't effect the } \\
\text { model outcome. We feel we made an attempt to } \\
\text { build upon the previous modeling activities by } \\
\text { incorporating data and conceptual ideas where } \\
\text { appropriate. Until LMES can convince DOE } \\
\text { and regulators for the need of recharge data we } \\
\text { will have to make assumptions. The alternative } \\
\text { is to not model until we have all of the hard data } \\
\text { covering all aspects of the hydrologic cycle. We } \\
\text { don't feel this approach would be acceptable to } \\
\text { our client, DoE. } \\
\text { Text will be added to state a number of recharge } \\
\text { scenarios were simulated. However, the best re- } \\
\text { sults were achieved by adding recharge along the } \\
\text { 001 Outfall and no recharge in the central } \\
\text { portion of the plant where large buildings and } \\
\text { pavement exist. We agree anthropogenic re- } \\
\text { charge needs to be quantified but it was beyond } \\
\text { the scope of this project to assess the impact of } \\
\text { recharge. We tried a number of recharge scenar- } \\
\text { ios. The scenario modeled resulted in the best } \\
\text { match of the Northwest plume. In our opinion, } \\
\text { if plume geometry is not simulated correctly it } \\
\text { makes little sense to perform capture zone } \\
\text { analysis. Are our assumptions correct? Given } \\
\text { the data available, namely discharge rates from } \\
\text { with the actual plume the assumptions appear } \\
\text { reasonable. }\end{array}$ \\
\hline
\end{tabular}




\section{U.S. DEPARTMENT OF ENERGY OAK RIDGE OPERATIONS}

\section{DESIGN REVIEW RECORD}

Project Title: Paducah Gaseous Diffusion Plant Northwest Plume Interceptor System Evaluation Date: 11/6/96 Job Title: Alan Laase and Jay Clausen Transmittal No.:

\begin{tabular}{|c|c|c|c|}
\hline $\begin{array}{l}\text { Item } \\
\text { No. }\end{array}$ & $\begin{array}{l}\text { Drawing or spec. } \\
\text { no. \& paragraph }\end{array}$ & Comments & $\begin{array}{c}\text { A-E } \\
\text { Action } \\
\end{array}$ \\
\hline 2 & $\begin{array}{l}\text { Drew Diefendorf } \\
\text { LMER } \\
\text { General Comment }\end{array}$ & $\begin{array}{l}\text { The discovery of the heretofore undocumented channel } \\
\text { seems somewhat contrived. Where is the geometry of this } \\
\text { channel documented in previous reports.? While it is } \\
\text { probable that channel deposits exist within the RGA, it is } \\
\text { also probable that they occur as a far more complex system } \\
\text { of remnant channel cutoffs, lenses and other somewhat } \\
\text { anastomosing bodies wherein the RGA can generally be } \\
\text { treated as a singular, albeit heterogeneous, hydrologic unit. }\end{array}$ & 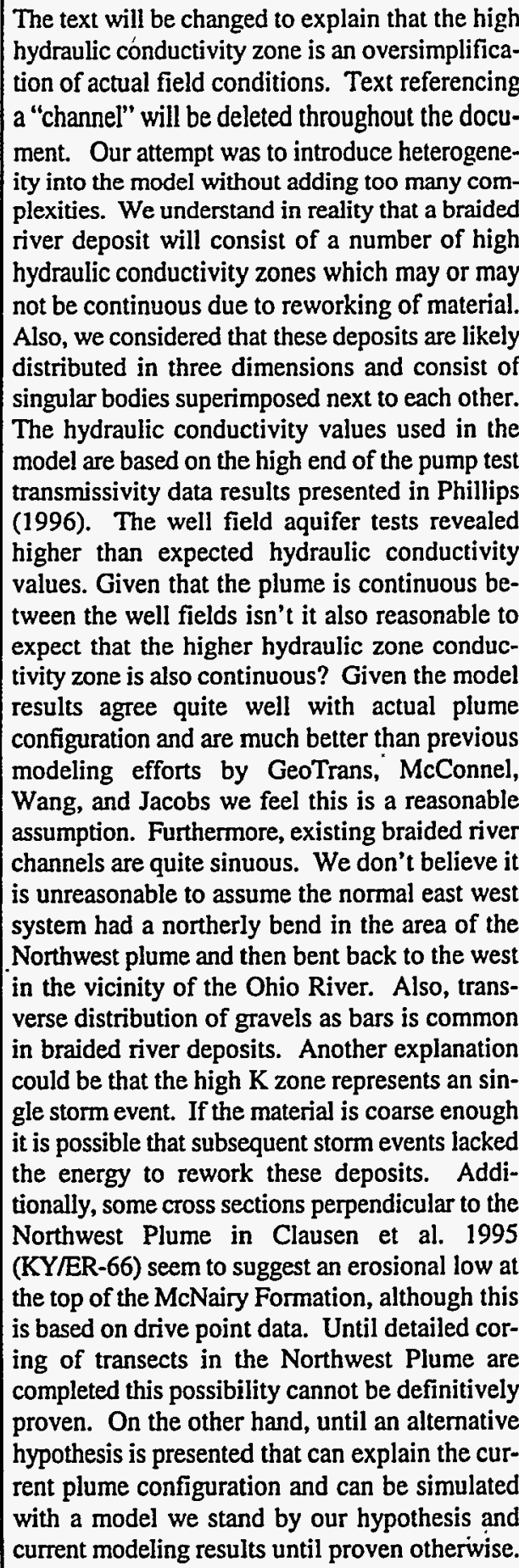 \\
\hline
\end{tabular}




\section{U.S. DEPARTMENT OF ENERGY}

OAK RIDGE OPERATIONS

\section{DESIGN REVIEW RECORD}

Project Title: _Paducah Gaseous Diffusion Plant Northwest Plume Interceptor System Evaluation Date: 11/6/96 Job Title: $\quad$ Alan Laase and Jay Clausen Transmittal No.:

\begin{tabular}{|c|c|c|c|}
\hline $\begin{array}{l}\text { Item } \\
\text { No. }\end{array}$ & $\begin{array}{l}\text { Drawing or spec. } \\
\text { no.\& paragraph }\end{array}$ & Comments & $\begin{array}{l}\text { A-E } \\
\text { Action }\end{array}$ \\
\hline 3 & $\begin{array}{l}\text { Drew Diefendorf } \\
\text { LMER } \\
\text { General Comment }\end{array}$ & $\begin{array}{l}\text { There appears to be some difficulty in evaluating piezo- } \\
\text { metric levels in the vicinity of the recovery field. This } \\
\text { needs to be explained and addressed. If we cannot measure } \\
\text { the effects of pumping in the field as seems to be the case, } \\
\text { how can we apply useable field data to a model or its cali- } \\
\text { bration.? It's difficult to convince me, if you can't measure } \\
\text { draw down adequately with the current monitoring system, } \\
\text { how will you prove the effectiveness of doubling of the } \\
\text { recovery rate? }\end{array}$ & $\begin{array}{l}\text { Text will be added to explain the difficulty in } \\
\text { assessing the cone of depression given the small } \\
\text { head changes. } \\
\text { The drawdown from pumping activities has no } \\
\text { relevance to the model. The model was cali- } \\
\text { brated with head data collected prior to pumping } \\
\text { activities. } \\
\text { One needs to keep in mind that drawdown and } \\
\text { the development of a cone of depression will not } \\
\text { be the same as the capture zone in our type of } \\
\text { hydrologic system. Even if we could measure } \\
\text { drawdown it won't tell you the extent of the } \\
\text { capture zone. Contaminants can be captured be- } \\
\text { yond the drawdown since the stream tubes up } \\
\text { gradient of the well field will be bent towards the } \\
\text { pumping wells. The only way it appears to } \\
\text { assess the extent of the capture zone is through } \\
\text { modeling or possibly with the colloidal bore- } \\
\text { scope. }\end{array}$ \\
\hline 4 & $\begin{array}{l}\text { Drew Diefendorf } \\
\text { LMER } \\
\text { General Comment }\end{array}$ & $\begin{array}{l}\text { Where are the plots of current potentiometric surfaces to } \\
\text { support arguments that the centroid is not being captured? }\end{array}$ & $\begin{array}{l}\text { We didn't intend to include since the focus of } \\
\text { the report was on the model results. }\end{array}$ \\
\hline 5 & $\begin{array}{l}\text { Drew Diefendorf } \\
\text { LMER } \\
\text { General Comment }\end{array}$ & $\begin{array}{l}\text { Given the important implications of this work, it is recom- } \\
\text { mended that the modeling effort be peer reviewed by } \\
\text { appropriate modeling folks within the ER program before } \\
\text { it is used for decision making purposes. }\end{array}$ & $\begin{array}{l}\text { The document was reviewed by individuals from } \\
\text { LMES, Jacobs, DOE and its subcontractors. We } \\
\text { agree review by a LMES modeler would be } \\
\text { desirable but as far as we are aware their are no } \\
\text { individuals within the LMES ER program at } \\
\text { Paducah or elsewhere with modeling expertise. }\end{array}$ \\
\hline 6 & $\begin{array}{l}\text { Ken Davis } \\
\text { LMES } \\
\text { Section } 3.0 \text {, } \\
\text { Conceptual Model }\end{array}$ & $\begin{array}{l}\text { Section 3.0, Conceptual Model: If you want to include it, } \\
\text { I have derived a horizontal K for the McNairy of } 1.8 \times \\
10 \mathrm{E}-2 \mathrm{ft} / \mathrm{d}(6.3 \times 10 \mathrm{E}-6 \mathrm{~cm} / \mathrm{s}) \text {. Reference is "The McNairy } \\
\text { Formation in the Area of the Paducah Gaseous Diffusion } \\
\text { Plant", Sept., } 1996 .\end{array}$ & $\begin{array}{l}\text { Thanks, we will reference this number in the } \\
\text { text. }\end{array}$ \\
\hline 7 & $\begin{array}{l}\text { Ken Davis } \\
\text { LMES } \\
\text { Section 5.2, } \\
\text { Boundary } \\
\text { Conditions }\end{array}$ & $\begin{array}{l}\text { Although I was an early proponent, I now believe modeling } \\
\text { the terrace as a no-flow boundary to be an error. The } \\
\text { boundary assumption for the terrace significantly detracts } \\
\text { from the acceptance of the results, in my view. }\end{array}$ & $\begin{array}{l}\text { We disagree modeling the terrace as a no flow } \\
\text { boundary detracts from the results. Changing } \\
\text { the boundary conditions of the terrace will have } \\
\text { minimal impact on the groundwater flow direc- } \\
\text { tion in the vicinity of the two extraction well } \\
\text { fields. Compare the results of the two GeoTrans } \\
\text { models, one which used an active cell the latter } \\
\text { as a no flow boundary. We agree some flow } \\
\text { likely occurs across the terrace but there is } \\
\text { insufficient data to quantify it. Although optimi- } \\
\text { zation could have been performed to assess the } \\
\text { flow across the terrace we felt this was beyond } \\
\text { the scope of the project. However, future model- } \\
\text { ing should address this concern. }\end{array}$ \\
\hline
\end{tabular}




\section{U.S. DEPARTMENT OF ENERGY OAK RIDGE OPERATIONS}

\section{DESIGN REVIEW RECORD}

Project Title: Paducah Gaseous Diffusion Plant Northwest Plume Interceptor System Evaluation Date: 11/6/96 Job Title: Alan Laase and Jav Clausen

\begin{tabular}{|c|c|c|c|}
\hline $\begin{array}{l}\text { Item } \\
\text { No. }\end{array}$ & $\begin{array}{l}\text { Drawing or spec. } \\
\text { no. \& paragraph } \\
\end{array}$ & Comments & $\begin{array}{c}\text { A-E } \\
\text { Action } \\
\end{array}$ \\
\hline 8 & $\begin{array}{l}\text { Ken Davis } \\
\text { LMES } \\
\text { General Comment }\end{array}$ & $\begin{array}{l}\text { All PGDP groundwater flow models are most sensitive to } \\
\text { our assumptions of RGA K and recharge (Fig. } 6.1 \text { ). Until } \\
\text { we come to terms with at least one of these parameters, } \\
\text { utilization of modeling - as attempted here - will be } \\
\text { stymied. Realistically, DOE isn't going to foot the bill to } \\
\text { adequately define either with field research. }\end{array}$ & $\begin{array}{l}\text { Agree, but as stated in the responses to com- } \\
\text { ments } \# 1 \text { and } \# 2 \text { we have to use the data we have } \\
\text { at hand and to employ reasonable assumptions } \\
\text { where hard data is lacking. }\end{array}$ \\
\hline 9 & $\begin{array}{l}\text { Ken Davis } \\
\text { LMES } \\
\text { General Comment }\end{array}$ & $\begin{array}{l}\text { I think the attempt to incorporate a model of RGA K (Fig. } \\
5.7 \text { is the correct response with these limitations. From } \\
\text { time-to-time, I have supported building a model just as you } \\
\text { have done. However, now that I see it, I don't like it. My } \\
\text { conceptual model of RGA deposition won't allow for the } \\
\text { NW Plume channel. So..I think we either need to research } \\
\text { depositional systems and agree to an RGA model or you } \\
\text { need to burden this report with the lithologic evidence for } \\
\text { the NW Plume channel. Otherwise, the assumptions of } \\
\text { RGA K are too speculative to } \\
\text { be comfortable with. }\end{array}$ & $\begin{array}{l}\text { See response to comment \#2. We believe the } \\
\text { way we modeled the system is reasonable given } \\
\text { the agreement between the modeled results and } \\
\text { the actual plume configuration. The altermative } \\
\text { was to utilize the existing models with no chan- } \\
\text { ges, which we deemed to be unacceptable given } \\
\text { that they did not accurately portray the known } \\
\text { flow system, based on the orientation of the } \\
\text { Northwest plume. If the model can't accurately } \\
\text { portray the plume geometry then this seems to us } \\
\text { to cast doubt on the capture zone analysis. }\end{array}$ \\
\hline 10 & $\begin{array}{l}\text { Ken Davis } \\
\text { LMES } \\
\text { General } \\
\text { Comment }\end{array}$ & $\begin{array}{l}\text { Other hydraulic controls are just as likely to explain the } \\
\text { location and shape of the NW Plume. I now think the } \\
\text { west-to-east flow that develops during high Ohio River } \\
\text { stage indicates the presence of a hydraulic 'driver' north- } \\
\text { west of the plant that explains the 'banana' curve to the } \\
\text { plume. }\end{array}$ & $\begin{array}{l}\text { We agree, the eastward flow has an impact on } \\
\text { the plume. However, this a transient feature } \\
\text { which only lasts for several months and does not } \\
\text { occur every year. So the impact on the flow sys- } \\
\text { tem and the plume orientation will be temporary. } \\
\text { The majority of the time the Ohio River stage is } \\
\text { at or near base level conditions which result in a } \\
\text { general northward flow direction. So, some } \\
\text { other feature likely explains the "banana" curve } \\
\text { which we believe to be heterogeneity. }\end{array}$ \\
\hline 11 & $\begin{array}{l}\text { Ken Davis } \\
\text { LMES } \\
\text { General Comment }\end{array}$ & $\begin{array}{l}\text { The absence of change in the south well field capture zone } \\
\text { modeled without the north well field (Fig. 7.3) versus with } \\
\text { the north well field (Fig. } 7.2 \text { ) doesn't appear right. Were } \\
\text { the capture zones in Fig. } 7.2 \text { modeled with both well fields } \\
\text { running concurrently? They should have been. }\end{array}$ & $\begin{array}{l}\text { The two well fields, operating at the simulated } \\
\text { pumping rates, do not "compete" for water. } \\
\text { Running one well field without the other will } \\
\text { not change the shape of the others capture zone. } \\
\text { The correct. well fields were operational for all } \\
\text { simulations. }\end{array}$ \\
\hline 12 & $\begin{array}{l}\text { Ken Davis } \\
\text { LMES } \\
\text { General Comment }\end{array}$ & $\begin{array}{l}\text { I think this report should go forward. Up front, we need to } \\
\text { highlight the critical assumptions that lead to the results: } 1 \text { ) } \\
\text { the Northwest Plume channel with high } \mathrm{K} \text { and } 2 \text { ) the } \\
\text { recharge model for plant site. Although the intent is to } \\
\text { evaluate the NW Plume containment system, perhaps the } \\
\text { value of this report is to demonstrate the application of } \\
\text { modeling and the need for further model development at } \\
\text { PGDP. }\end{array}$ & $\begin{array}{l}\text { We agree and will add the caveats up front in the } \\
\text { introduction. As mentioned in the recommenda- } \\
\text { tion we feel much would be gained in under- } \\
\text { standing recharge and heterogeneity by simply } \\
\text { sitting down with the model for several months } \\
\text { and playing around with the input parameters. }\end{array}$ \\
\hline 13 & $\begin{array}{l}\text { Ross Miller } \\
\text { LMES } \\
\text { Page 6-10,6.3: }\end{array}$ & Good opening paragraph. & Thanks. \\
\hline
\end{tabular}




\begin{tabular}{|c|c|c|c|}
\hline \multicolumn{3}{|c|}{$\begin{array}{l}\text { U.S. DEPARTMENT OF ENERGY } \\
\text { OAK RIDGE OPERATIONS }\end{array}$} & $\begin{array}{c}\text { DESIGN } \\
\text { REVIEW RECORD }\end{array}$ \\
\hline \multicolumn{3}{|c|}{ 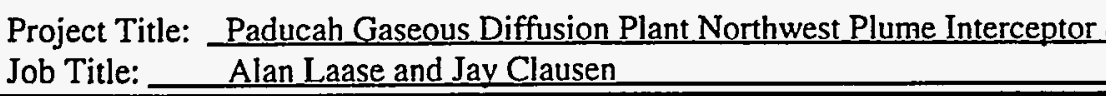 } & $\begin{array}{c}\text { System Evaluation Date: } 11 / 6 / 96 \\
\text { Transmittal No.: }\end{array}$ \\
\hline $\begin{array}{l}\text { Item } \\
\text { No. }\end{array}$ & $\begin{array}{l}\text { Drawing or spec. } \\
\text { no. \& paragraph }\end{array}$ & Comments & $\begin{array}{l}\text { A-E } \\
\text { Action }\end{array}$ \\
\hline 14 & $\begin{array}{l}\text { Ross Miller } \\
\text { LMES } \\
\text { Page 6-17, } \\
\text { middle paragraph }\end{array}$ & $\begin{array}{l}\text { I agree. I suspect the C- } 400 \text { area is contributing to the } \\
\text { Northeast Plume. However, I would tread carefully here as } \\
\text { the Tc- } 99 \text { fingerprint at C- } 400 \text { does not indicate this area } \\
\text { as a major contributor to the Northeast Plume. }\end{array}$ & $\begin{array}{l}\text { We agree with your concem text will be changed } \\
\text { to reflect the uncertainty based on the assump- } \\
\text { tions inherit to the model. The model runs sug- } \\
\text { gest that changes in the discharge rate at Outfall } \\
\text { 011 have a major impact on the RGA hydraulics. } \\
\text { This in turn impacts recharge to the RGA and } \\
\text { ultimately grouridwater flow directions and con- } \\
\text { taminant transport from C- } 400 \text {. The lagoon did } \\
\text { not come on line until } 1977 \text { prior to this } \\
\text { discharge was into the N/S ditch. Most of the } \\
\text { plant upgrades which resulted in the recovery of } \\
\text { Tc-99 occurred prior to } 1977 \text {. Thus, ground- } \\
\text { water contamination from C-400 which con- } \\
\text { tained Tc-99 would have migrated to the North- } \\
\text { west away from C-400. Thus, only post } 1977 \\
\text { water and contaminants would be contributing to } \\
\text { the Northeast Plume. This seems to support the } \\
\text { lower levels of Tc-99 seen in the Northeast } \\
\text { Plume and the lessor longitudinal extent as com- } \\
\text { pared to the Northwest Plume. If one uses the } \\
1977 \text { date as the start of the Northeast Plume the } \\
\text { longitudinal extent is in agreement with expected } \\
\text { average flow velocities of } 1 \text { ft/day. }\end{array}$ \\
\hline 15 & $\begin{array}{l}\text { Ross Miller } \\
\text { LMES } \\
\text { Page 6-17, } \\
\text { last paragraph }\end{array}$ & $\begin{array}{l}\text { No doubt the } 001 \text { Outfall influences the hydraulics in the } \\
\text { UCRS and RGA. However, as pointed out in the WAG } 6 \text {, } \\
\text { Phase I hydrogeological study, there are many anthropo- } \\
\text { genic recharge areas as potential contributors to flow paths } \\
\text { of the plume(s). I suggest eliminating your statement relat- } \\
\text { ing to } 001 \text { as I believe it will be very difficult to defend this } \\
\text { position. Rather, reword stating that Outfall 001 was used } \\
\text { as an "assumptive means" to duplicate a complex recharge } \\
\text { system. }\end{array}$ & $\begin{array}{l}\text { We will clarify the text to state this was the only } \\
\text { scenario, of several tried, which had the desired } \\
\text { impact of mimicking the Northwest Plume } \\
\text { orientation and location. We would like to point } \\
\text { out that the leakance rate fits reasonably well } \\
\text { with the known discharge rate for this Outfall. } \\
\text { We agree that other areas of anthropogenic re- } \\
\text { charge may also effect the flow system but given } \\
\text { the limited time and budget we could only assess } \\
\text { several scenarios. }\end{array}$ \\
\hline 16 & $\begin{array}{l}\text { Ross Miller } \\
\text { LMES } \\
\text { Page 7-1, 7.1, } \\
\text { first paragraph }\end{array}$ & The last sentence is misleading; would rewrite. & $\begin{array}{l}\text { The text will be changed to clarify the point we } \\
\text { are trying to make, which is that it appears there } \\
\text { is a zone of non capture between the two well } \\
\text { fields, ie. contaminants from C- } 400 \text { are migrat- } \\
\text { ing past both the south and north well field at the } \\
\text { current } 50 \text { gpm pumping rate. In reality we be- } \\
\text { lieve the contaminants from C-400 migrate } \\
\text { directly under SWMUs } 7 \& 30 \text {, unfortunately we } \\
\text { could not get the modeled plume to perfectly } \\
\text { simulate the actual plume. }\end{array}$ \\
\hline 17 & $\begin{array}{l}\text { Ross Miller, } \\
\text { LMES } \\
\text { Page } 8-1,8.0 \\
\end{array}$ & $\begin{array}{l}\text { I would move those paragraphs relating to future } \\
\text { recommendation to Section } 10.0 \text {. }\end{array}$ & $\begin{array}{l}\text { Agree, we will move these to the Recommenda- } \\
\text { tion section. }\end{array}$ \\
\hline 18 & $\begin{array}{l}\text { Ross Miller } \\
\text { LMES } \\
\text { General Comment }\end{array}$ & $\begin{array}{l}\text { I definitely believe your report has enhanced our under- } \\
\text { standing of the Northwest Plume and also identified areas } \\
\text { of potential data gaps. I am not a modeler and do not claim } \\
\text { to be one. However, I do understand the limitations and } \\
\text { use of models (see attached letter dated } 6 / 17 / 96 \text {, "Ground- } \\
\text { water Modeling, The Real World") and suggest you } \\
\text { include some general caveats to that effect. }\end{array}$ & $\begin{array}{l}\text { Thanks, we will add some text indicating that } \\
\text { modeling is an iterative process. Thus, earlier } \\
\text { modeling attempts are not necessarily wrong but } \\
\text { rather are limited by the data available and un- } \\
\text { derstanding of the hydrologic system for that } \\
\text { point in time. }\end{array}$ \\
\hline
\end{tabular}




\section{U.S. DEPARTMENT OF ENERGY OAK RIDGE OPERATIONS}

\section{DESIGN REVIEW RECORD}

Project Title: Paducah Gaseous Diffusion Plant Northwest Plume Interceptor System Evaluation Date: 11/6/96 Job Title: Alan Laase and Jay Clausen Transmittal No.:

\begin{tabular}{|c|c|c|c|}
\hline $\begin{array}{l}\text { Item } \\
\text { No. }\end{array}$ & $\begin{array}{l}\text { Drawing or spec. } \\
\text { no. \& paragraph }\end{array}$ & Comments & $\begin{array}{l}\text { A-E } \\
\text { Action }\end{array}$ \\
\hline 19 & $\begin{array}{l}\text { Bruce Phillips } \\
\text { Jacobs Eng. } \\
\text { Pg. vi, 2nd } \\
\text { paragraph; } \\
\text { Pg. 7-1, } \\
\text { 3rd paragraph; } \\
\text { Pg. 7-3, } \\
\text { 1st full sentence; } \\
\text { Pg. 9-1, 1st bullet }\end{array}$ & $\begin{array}{l}\text { In the text locations noted, it is stated that model results } \\
\text { suggest the plume "hotspot" is not contained at the current } \\
\text { pumping rate. However, based on Fig. } 7.1 \text {, the current } \\
\text { pumping rates are adequate for "hotspot" containment. } \\
\text { Based on Fig. 7.1, the capture zone widths for the North } \\
\text { and South Well Fields are approximately } 500 \mathrm{ft} \text { and } 1,000 \\
\mathrm{ft} \text { respectively. The plume cores defined by TCE greater } \\
\text { than } 1,000 \mu \mathrm{g} / 1 \text { have widths of approximately } 350 \mathrm{ft} \text { and } \\
600 \mathrm{ft} \text { in the North and South Well Fields respectively. } \\
\text { Page 7-1 (3rd para., 3rd sent.) incorrectly reports values of } \\
\text { hydraulic conductivity estimated from the aquifer test (see } \\
\text { comment \#2 below). In the preliminary capture zone } \\
\text { analysis reported in Phillips (1996), hydraulic conductivity } \\
\text { values of } 1,000 \text { ft/d and } 2,500 \text { ft/d for the South and North } \\
\text { Well Fields, respectively, were used based on results of the } \\
\text { Hantush-Jacob analyses of the aquifer test. Based on the } \\
\text { Hantush-Jacobs solution, conductivities in the south ranged } \\
\text { from } 800 \text { to } 1300 \mathrm{ft} / \mathrm{d} \text { with a geometric mean of about } \\
1,050 \mathrm{ft} / \mathrm{d} \text {. Hydraulic conductivities in the north ranged } \\
\text { from } 2,685 \text { to } 3,025 \mathrm{ft} / \mathrm{d} \text { with a geometric mean of } 2,850 \\
\mathrm{ft} / \mathrm{d} \text {. The Hantush-Jacobs values are more appropriate } \\
\text { since the RGA is confined by a leaky aquitard - it's more } \\
\text { consistent with the conceptual model. } \\
\text { - }\end{array}$ & $\begin{array}{l}\text { While most of the plume "hotspot" is contained } \\
\text { the C-400 Building, a known source area. is } \\
\text { located between the simulated capture zones. } \\
\text { Therefore, as simulated, contamination emanat- } \\
\text { ing from this source area will allude capture. } \\
\text { Based on the location of the C-400 Building } \\
\text { with respect to the capture zones containment } \\
\text { was deemed inadequate. } \\
\text { North well field transmissivities ranged from } \\
75,208158,563 \mathrm{ft}^{2} / \mathrm{d} \text { (Phillips } 1996 \text { ). Based on } \\
\text { a north well field RGA thickness of } 20 \mathrm{ft} \\
\text { (Phillips 1996), north well field hydraulic con- } \\
\text { ductivities ranged from } 3,760 \text { to } 7,928 \mathrm{ft} / \mathrm{d} \text {. } \\
\text { Similarly, based on a transmissivity range of } \\
25,088 \text { to } 49,328 \text { ft }{ }^{2} / \mathrm{d} \text { and a thickness of } 30 \mathrm{ft} \\
\text { south well field hydraulic conductivities ranged } \\
\text { from } 836 \text { to } 1,644 \mathrm{ft} / \mathrm{d} \text {. The text will be modi- } \\
\text { fied to reflect these ranges. } \\
\text { Phillips (1996) did not specify which aquifer } \\
\text { analysis method yielded the most accurate } \\
\text { hydraulic conductivity predictions. Therefore, } \\
\text { we assumed all values within a hydraulic } \\
\text { conductivity range were possible. } \\
\text { A number of error sources can introduce } \\
\text { variability in pumping test results. Sources of } \\
\text { error include errors in adjusting drawdowns, } \\
\text { position of the best-fit curve with respect to the } \\
\text { plot of draw down verses time, and assumed } \\
\text { RGA aquifer thickness. As a consequence, the } \\
\text { predicted hydraulic conductivity ranges for the } \\
\text { two pumping tests is probably larger than that re- } \\
\text { ported in Phillips (1996). Thus, use of model } \\
\text { hydraulic conductivity values minimally out of } \\
\text { range of the Phillips (1996) values is acceptable. }\end{array}$ \\
\hline 20 & $\begin{array}{l}\text { Bruce Phillips } \\
\text { Jacobs Eng. } \\
\text { Pg. 1-1, } \\
\text { 1st paragraph; } \\
\text { Pg. 3-1, } \\
\text { 1st paragraph; }\end{array}$ & $\begin{array}{l}\text { In the paragraphs noted, it is stated that Phillips, } 1996 \\
\text { estimated hydraulic conductivities in the RGA up to } 8,000 \\
\mathrm{ft} / \mathrm{d} \text {. The range of hydraulic conductivities in the south was } \\
\text { from } 800 \mathrm{ft} / \mathrm{d} \text { to } 1,430 \mathrm{ft} / \mathrm{d} \text { with a geometric mean of } 1,175 \\
\mathrm{ft} / \mathrm{d} \text {. The range of hydraulic conductivities in the north was } \\
\text { from } 2,685 \mathrm{ft} / \mathrm{d} \text { to } 5,700 \mathrm{ft} / \mathrm{d} \text { with a geometric mean of } \\
3,740 \mathrm{ft} / \mathrm{d} \text {. }\end{array}$ & $\begin{array}{l}\text { Figure } 5 \text { in Phillips (1996) shows RGA thickness } \\
\text { in the vicinity of the north well field to be } \\
\text { approximately } 20 \mathrm{ft} \text {. Based on this thickness } \\
\text { north well field hydraulic conductivities range } \\
\text { from } 3,760 \text { to } 7,928 \mathrm{ft} / \mathrm{d} \text {. Thus the statement } \\
\text { that Phillips (1996) estimated hydraulic conduc- } \\
\text { tivities up to } 8,000 \mathrm{ft} / \mathrm{d} \text { is correct. } \\
\text { See comment response } 1 \text { for additional detail. }\end{array}$ \\
\hline 21 & $\begin{array}{l}\text { Bruce Phillips } \\
\text { Jacobs Eng. } \\
\text { Pg. 3-1, 1st para., } \\
\text { 6th sentence }\end{array}$ & $\begin{array}{l}\text { The range of thickness of the RGA is approximately } \\
0 \mathrm{ft} \text { to } 50 \mathrm{ft} \text {. }\end{array}$ & Agree, text will be changed. \\
\hline 22 & $\begin{array}{l}\text { Bruce Phillips } \\
\text { Jacobs Eng. } \\
\text { Pg. 3-1, 2nd para., } \\
\text { 1st sentence }\end{array}$ & $\begin{array}{l}\text { While the Porters. Creek Clay provides an overlying } \\
\text { confining layer for the McNairy Formation south of the } \\
\text { PGDP, it does not "bound" the hydrogeological unit as } \\
\text { implied here. }\end{array}$ & Agreed, the text will be changed accordingly. \\
\hline
\end{tabular}




\begin{tabular}{|c|c|c|c|}
\hline \multicolumn{3}{|c|}{$\begin{array}{l}\text { U.S. DEPARTMENT OF ENERGY } \\
\text { OAK RIDGE OPERATIONS }\end{array}$} & $\begin{array}{c}\text { DESIGN } \\
\text { REVIEW RECORD }\end{array}$ \\
\hline \multicolumn{4}{|c|}{$\begin{array}{l}\text { Project Title: } \frac{\text { Paducah Ga }}{\text { Alan Laase }} \\
\text { Job Title: }\end{array}$} \\
\hline $\begin{array}{l}\text { Item } \\
\text { No. } \\
\end{array}$ & $\begin{array}{l}\text { Drawing or spec. } \\
\text { no. \& paragraph }\end{array}$ & Comments & $\begin{array}{c}\text { A-E } \\
\text { Action }\end{array}$ \\
\hline 23 & $\begin{array}{l}\text { Bruce Phillips } \\
\text { Jacobs Eng. } \\
\text { Pg. 5-5, } \\
\text { 4th paragraph. }\end{array}$ & $\begin{array}{l}\text { Why were the lagoons not considered as sources of } \\
\text { anthropogenic recharge? It has been postulated that } C-616 \\
\text { may contribute technetium to ground water via recharge. }\end{array}$ & $\begin{array}{l}\text { Borescope measurements at MW173 and } \\
\text { MW186 indicated northward groundwater flow, } \\
\text { which is not consistent with leaking lagoons. } \\
\text { Thus, the lagoon was not simulated as a source } \\
\text { of recharge. Characterization efforts should be } \\
\text { undertaken to determine if this is a valid assump- } \\
\text { tion. }\end{array}$ \\
\hline 24 & $\begin{array}{l}\text { Bruce Phillips } \\
\text { Jacobs Eng. } \\
\text { Pg. 5-8, } \\
\text { 1st paragraph; } \\
\text { Fig. } 5.7\end{array}$ & $\begin{array}{l}\text { The text noted states the hydraulic conductivity zones } \\
\text { within the "channel" are based on expected fluvial deposi- } \\
\text { tional patterns but these patterns are not discussed in the } \\
\text { text. The depositional system responsible for the lower } \\
\text { continental deposits (approximately } 6 \text { mile wide belt with } \\
\text { gravel and sand from } 0 \text { to } 60 \mathrm{ft} \text { thick) has often been } \\
\text { interpreted as braided to coarse-grained meandering fluvial } \\
\text { system. It would be unrealistic to include only one sinuous } \\
\text { channel deposit within an area dominated by channel } \\
\text { facies. If the high conductivity zones depicted in Fig. } 5.7 \\
\text { are meant to represent a meandering channel deposit, I } \\
\text { would expect the high conductivity zone to be more } \\
\text { broadly represented as the channel migrated across the } \\
\text { area. }\end{array}$ & $\begin{array}{l}\text { Agreed, the text will be modified to state that the } \\
\text { modeling approach is an oversimplification of } \\
\text { the depositional environment. Also, all text im- } \\
\text { plying a "single" channel will be modified. } \\
\text { However, it is possible that a single storm event } \\
\text { resulted in coarse material being deposited } \\
\text { linearly between the two well fields. Subsequent } \\
\text { storm events may have lacked the energy to } \\
\text { rework these deposits. }\end{array}$ \\
\hline 25 & $\begin{array}{l}\text { Bruce Phillips } \\
\text { Jacobs Eng. } \\
\text { Pg. 6-17, } \\
\text { 1 st full paragraph, } \\
\text { 8th sentence }\end{array}$ & $\begin{array}{l}\text { While portions of the NE Plume complex may be related to } \\
\text { dissolved phase contamination from the UCRS, the plume } \\
\text { core along the southern margin of the plume complex has } \\
\text { higher concentrations of TCE at the base of the RGA, } \\
\text { indicating a likely RGA source. }\end{array}$ & $\begin{array}{l}\text { A higher concentration in part of the NE plume } \\
\text { does not necessarily indicate a DNAPL source in } \\
\text { the RGA. While flow within the RGA is } \\
\text { primarily horizontal vertical stratification must } \\
\text { occur. Groundwater entering the RGA near the } \\
\text { southen site boundary moves vertically as it } \\
\text { flows toward the Ohio River to accommodate } \\
\text { "new" groundwater entering the RGA. Thus, it } \\
\text { is possible to have stratified, both horizontally } \\
\text { and vertically, contaminant concentrations with } \\
\text { out having a DNAPL source in the RGA. The } \\
\text { text will be reworded that this is one of several } \\
\text { hypothesis. Agreed, sources other than C-400 } \\
\text { could be and are likely feeding this plume. } \\
\text { However, our focus was not on the Northeast } \\
\text { Plume. We only mentioned this because of the } \\
\text { interesting result. }\end{array}$ \\
\hline 26 & $\begin{array}{l}\text { Caroline Bäber } \\
\text { Jacobs Eng. } \\
\text { Page 2-1 }\end{array}$ & $\begin{array}{l}\text { Why have conventional methods of hot spot containment } \\
\text { evaluation (such as potentiometric surface mapping and } \\
\text { contaminant monitoring proven) proven ineffective? }\end{array}$ & $\begin{array}{l}\text { Text will be added that the current configuration } \\
\text { of monitoring wells is not conducive for } \\
\text { evaluating drawdown at the current pumping } \\
\text { rates. The low pumping rates hardly stress the } \\
\text { aquifer and result in negligible drawdown. } \\
\text { Additionally, cyclical trends in contaminant } \\
\text { levels are not conducive to isopleth mapping of } \\
\text { TCE levels. }\end{array}$ \\
\hline 27 & $\begin{array}{l}\text { Caroline Barber } \\
\text { Jacobs Eng. } \\
\text { Page 5-1 }\end{array}$ & $\begin{array}{l}\text { The McNairy Formation should have been included in this } \\
\text { model. }\end{array}$ & $\begin{array}{l}\text { As discussed in the text, because of how the } \\
\text { GeoTrans model was configured the McNairy } \\
\text { did not influence groundwater flow or contami- } \\
\text { nant migration in the vicinity of the two well } \\
\text { fields. Thus, no benefit would have been gained } \\
\text { by including the McNairy in the model. }\end{array}$ \\
\hline
\end{tabular}




\section{U.S. DEPARTMENT OF ENERGY OAK RIDGE OPERATIONS}

\section{DESIGN REVIEW RECORD}

Project Title: Paducah Gaseous Diffusion Plant Northwest Plume Interceptor System Evaluation Date: 11/6/96 Job Title: _ Alan Laase and Jay Clausen

\begin{tabular}{|c|c|c|c|}
\hline $\begin{array}{l}\text { Item } \\
\text { No. }\end{array}$ & $\begin{array}{l}\text { Drawing or spec. } \\
\text { no. \& paragraph }\end{array}$ & Comments & $\begin{array}{c}\text { A-E } \\
\text { Action } \\
\end{array}$ \\
\hline 28 & $\begin{array}{l}\text { Caroline Barber } \\
\text { Jacobs Eng. } \\
\text { Page 5-5, } \\
\text { Sect 5-3, Para. } 2\end{array}$ & $\begin{array}{l}\text { Why was just ditch } 001 \text { used to estimate industrial } \\
\text { recharge? What are these simplifying assumptions based } \\
\text { upon? The industrial hydrologic survey could not put a } \\
\text { number on this recharge, and could not even bracket it very } \\
\text { well. Please explain. }\end{array}$ & $\begin{array}{l}\text { As stated in the report, the } 001 \text { Outfall ditch is } \\
\text { expected to leak significant quantities of water } \\
\text { because the ditches length ( } 5000 \text {-ft), it is unlined } \\
\text { and transmits a large quantity of water. Other } \\
\text { ditches also undoubtedly leak. However, be- } \\
\text { cause of ditch lengths and water volumes trans- } \\
\text { mitted leakage rates from the other ditches are } \\
\text { not expected to be as significant. You are cor- } \\
\text { rect that the industrial hydrology study did not } \\
\text { quantify leakage rates from industrial features } \\
\text { and identifying the leakage rates as critical } \\
\text { information needed to accurately simulate the } \\
\text { site. Ken Davis, EIMS, provided the Outfall } 001 \\
\text { discharge rates. }\end{array}$ \\
\hline 29 & $\begin{array}{l}\text { Caroline Barber } \\
\text { Jacobs Eng. } \\
\text { Page 5-8 }\end{array}$ & $\begin{array}{l}\text { I'm not sure it makes sense to use 'plume geometry' to } \\
\text { justify the delineation of a high conductivity channel, and } \\
\text { then use particle tracking to justify that the model is } \\
\text { correctly tracking the plumes. Putting such a high conduc- } \\
\text { tivity channel into the model where the plumes are located } \\
\text { will naturally tend to make to model track the plumes that } \\
\text { direction. }\end{array}$ & $\begin{array}{l}\text { The text will be changed from a channel to } \\
\text { high conductivity zone. The high hydraulic } \\
\text { conductivity zone was located using a combina- } \\
\text { tion of plume geometry and aquifer test results. } \\
\text { The well field aquifer tests revealed higher than } \\
\text { expected hydraulic conductivity values. Given } \\
\text { that the plume is continuous between the well } \\
\text { fields isn't it also reasonable to expect that the } \\
\text { higher hydraulic zone conductivity zone is also } \\
\text { continuous? }\end{array}$ \\
\hline 30 & $\begin{array}{l}\text { Caroline Barber } \\
\text { Jacobs Eng. } \\
\text { Page 5-8, Sect. } 5.4\end{array}$ & $\begin{array}{l}\text { This type of conductivity zonation will force the plume } \\
\text { directions. I think this zonation is an over simplification of } \\
\text { the system. }\end{array}$ & $\begin{array}{l}\text { We agree that the model configuration will } \\
\text { dictate model predictions. However, the zona- } \\
\text { tion employed is probably no more of an over } \\
\text { simplification of the system than that used in } \\
\text { other site models. The system simplifications } \\
\text { are acceptable given the available data. }\end{array}$ \\
\hline 31 & $\begin{array}{l}\text { Caroline Barber } \\
\text { Jacobs Eng. } \\
\text { Page } 5-10 \text {, } \\
\text { Fig. } 5.7\end{array}$ & $\begin{array}{l}\text { The delineation of the relic channels within the RGA using } \\
\text { conductivity zones seems to be almost entirely based upon } \\
\text { the graphical depiction of the plumes' geometries. This } \\
\text { needs to be documented using detailed cross sections along } \\
\text { with the pump test data, to justify making these con- } \\
\text { ductivity zones match the plumes so exactly. Please add } \\
\text { lithologic data and cross sections to justify the delineation } \\
\text { of these conductivity zones. }\end{array}$ & $\begin{array}{l}\text { Limited lithologic information, most of the } \\
\text { water-quality data in the area was obtained using } \\
\text { drive-point techniques, makes it difficult to } \\
\text { prove or disprove the existence of a higher } \\
\text { hydraulic conductivity channel solely based on } \\
\text { lithologic descriptions. As stated in comment } \\
\text { response } 29 \text {, given the higher than expected hy- } \\
\text { draulic conductivities at the two well fields and } \\
\text { that the plume is continuous between the well } \\
\text { fields isn't it also reasonable to expect that the } \\
\text { higher hydraulic zone conductivity zone is also } \\
\text { continuous? } \\
\text { Additional documentation concerning lithology } \\
\text { will not be added to the report since it is beyond } \\
\text { the scope of this project. }\end{array}$ \\
\hline 32 & $\begin{array}{l}\text { Caroline Barber } \\
\text { Jacobs Eng. } \\
\text { Page 6-1, Sect. } 6.3\end{array}$ & $\begin{array}{l}\text { Why was the model calibrated to the same time as the } 1992 \\
\text { analysis? It would have been a good idea to do a thorough } \\
\text { analysis of all of the water level data available to date, as } \\
\text { well as Ohio River stage data, to determine what the } \\
\text { optimum calibration time is. }\end{array}$ & $\begin{array}{l}\text { GeoTrans } 1992 \text { calibration target values are } \\
\text { reasonable calibration targets. Analysis of the } \\
\text { hydrologic data in the manner suggested is be- } \\
\text { yond the scope of this project. Given the recent } \\
\text { understanding of the significance in change in } \\
\text { flow direction a transient model may be appro- } \\
\text { priate and thus there are no optimum steady-state } \\
\text { calibration targets. }\end{array}$ \\
\hline 33 & $\begin{array}{l}\text { Caroline Barber } \\
\text { Jacobs Eng. } \\
\text { Page 6-2, } \\
\text { Fig. } 6.1\end{array}$ & $\begin{array}{l}\text { This figure is meaningless if it is not in color. Unless all } \\
\text { users of this document can get color copies, perhaps this } \\
\text { figure could be modified to be understandable in black and } \\
\text { white copies. }\end{array}$ & $\begin{array}{l}\text { The document will be distributed with color } \\
\text { figures since these are easier to portray the infor- } \\
\text { mation than in black and white. }\end{array}$ \\
\hline
\end{tabular}




\section{U.S. DEPARTMENT OF ENERGY OAK RIDGE OPERATIONS}

\section{DESIGN REVIEW RECORD}

Project Title: Paducah Gaseous Diffusion Plant Northwest Plume Interceptor System Evaluation Date: 111/6/96 Job Title: $\quad$ Alan Laase and Jay Clausen

\begin{tabular}{|c|c|c|c|}
\hline $\begin{array}{l}\text { Item } \\
\text { No. }\end{array}$ & $\begin{array}{l}\text { Drawing or spec. } \\
\text { no. \& paragraph }\end{array}$ & Comments & $\begin{array}{c}\text { A-E } \\
\text { Action } \\
\end{array}$ \\
\hline 34 & $\begin{array}{l}\text { Caroline Barber } \\
\text { Jacobs Eng. } \\
\text { Page 6-5, Sect. } 6.4\end{array}$ & $\begin{array}{l}\text { This simulates the flow field of the NW Plume because it } \\
\text { is forced that way by the hydraulic conductivity zonation } \\
\text { put into the model. }\end{array}$ & See comment response to 29 and 30 . \\
\hline 35 & $\begin{array}{l}\text { Caroline Barber } \\
\text { Jacobs Eng. } \\
\text { Page } 8-1, \text { Para. } 1\end{array}$ & $\begin{array}{l}\text { Past models have already addressed these deficiencies. } \\
\text { The UCRS update suggested here was already done by } \\
\text { another DOE model developed by the Jacobs EM Team } \\
\text { (DOE, 1994), which simulates the UCRS as two discrete } \\
\text { layers. }\end{array}$ & $\begin{array}{l}\text { We are pleased to see that others also recognized } \\
\text { the deficiencies of the GeoTrans model and im- } \\
\text { plemented corrective measures. }\end{array}$ \\
\hline 36 & $\begin{array}{l}\text { Caroline Barber } \\
\text { Jacobs Eng. } \\
\text { Page } 8-1 \text {, Para. } 4\end{array}$ & $\begin{array}{l}\text { A thorough evaluation of water level data and Ohio River } \\
\text { stage data would have been beneficial here. Potentiometric } \\
\text { surface maps would have been helpful as well. Please } \\
\text { explain about the shifting of the RGA ground water flow } \\
\text { from a northerly direction to an easterly one. }\end{array}$ & $\begin{array}{l}\text { Agree, this information would be beneficial but } \\
\text { this is beyond the scope of this project. This } \\
\text { information has been included in the Annual } \\
\text { Report for the Northwest Plume O\&M } \\
\text { DOE/OR/07-1531\&D1. }\end{array}$ \\
\hline
\end{tabular}

37 Caroline Barber The Jacobs EM Team model already includes the terrace Jacobs Eng. Page 8-2, Para 1 recent lithology data from the WAGs $1 \& 7$ investigation, as

We were not aware the (DOE 1994) model had been updated with this information. well as the Northeast Plume investigation. There is no reason to further update this model when another model already incorporates this data.

38 Caroline Barber Jacobs Eng.

A current model already includes the McNairy Formation in its structure. This has already been incorporated into the Page 8-2, Para. 2 model developed by the Jacobs Em team.

39 Caroline Barber Jacobs Eng. Page 10-1, Bullets $1,2,3,4$

Most of these recommended 'updates' have been already incorporated into the model developed by the Jacobs EM team. It would have been helpful to have used a model that incorporated much of the data gathered since 1992. It is not clear why recommendations for updates are made without mentioning the DOE already possesses a model which incorporates these updates?

40 Catherine Woehr Jacobs Eng. Pg. 3-1, para 1. Last sent.

41 Catherine Woehr Jacobs Eng. Pg. 5-5, Sect. 5.3

42 Catherine Woehr Jacobs Eng. General Comment
"Although the McNairy hydraulic conductivity has never been measured...." Suggest adding "at the PGDP", as I believe the McNairy hydraulic conductivity has been measured in the laboratory) by the USGS.

Groundwater sources and sinks: suggest adding a figure showing the location of Ditch 001 as well as the locations of other potentially significant anthropogenic sources of recharge in the vicinity of the NW Plume. Was any attempt made to quantify and incorporate into the model the amount of recharge coming from the $C-616$ lagoons? Their proximity to the bend in the Northwest Plume could be coincidental but should be addressed.

The report needs more justification, (including crosssections and/or gravel/sand percentage maps) for the mapped geometry of the relic channel shown in Fig. 5-10. Please further explain, as the existence of a single channel with a narrow, very high $\mathrm{K}$ zone does not conform to the generalized depositional history presented in the Groundwater Phase III report (which hypothesized braided channel deposits) and it represents a large change from the original 1993 GeoTrans model. Would a single channel adequately account for the configuration of the Tc-99 plume as well?
Thank you for the information.

See comment \#37. Additionally, when LMES was presented with the information from the DOE, 1994 model we had some concerns about the results. Specifically, the hydraulic conductivities used in the model were too low and the model did not accurately depict the geometry of the Northeast Plume. We were not aware any changes had been made to this model since 1994.

Agreed, the sentence will be changed to state the hydraulic conductivity of the McNairy has never been measured in situ at the site.

The ditch is shown in Fig. 5.4 although it is hard to see since it is a line. Although anthropogenic recharge is believed important at the site, the sources, locations, and discharge quantities have yet to be characterized.

See Comment Response \# 23 and \#28.

See comment response 31 . We don't see any particular disagreement with idea of highly conductive zones within the RGA orientated in a north-south direction as a conflict with a braided depositional environment. The only change from the GeoTrans, (1992) model is the inclusion of heterogeneity. This heterogeneity causes the simulated plume to reasonably track the real plume. The configuration of the Tc-99 plume has never been adequately defined and to date has been developed through extensive creativity. 


\section{U.S. DEPARTMENT OF ENERGY OAK RIDGE OPERATIONS}

\section{DESIGN REVIEW RECORD}

Project Title: Paducah Gaseous Diffusion Plant Northwest Plume Interceptor System Evaluation Date: 11/6/96 Job Title: Alan Laase and Jay Clausen Transmittal No.:

\begin{tabular}{|c|c|c|c|}
\hline $\begin{array}{l}\text { Item } \\
\text { No. }\end{array}$ & $\begin{array}{l}\text { Drawing or spec. } \\
\text { no. \& paragraph }\end{array}$ & Comments & $\begin{array}{c}\text { A-E } \\
\text { Action } \\
\end{array}$ \\
\hline 43 & $\begin{array}{l}\text { Steve Miller } \\
\text { Jacobs Eng. } \\
\text { General Comment }\end{array}$ & $\begin{array}{l}\text { The report indicates that the ROD stated the interceptor } \\
\text { system shall be operated to contain the hotspot of the } \\
\text { plume. The language in the ROD was carefully chosen to } \\
\text { not state control of the hotspot. For example the language } \\
\text { "ground water will be pumped at a rate to reduce further } \\
\text { contamination" and "The primary objective of the interim } \\
\text { action is to stabilize the site by initiating control of the of } \\
\text { the northwest contamination plume." were used. Although } \\
\text { the ROD also indicates the rates will be adjusted to } \\
\text { optimized the system, DOE didn't commit to control of the } \\
\text { high concentration area. Before the system is modified or } \\
\text { a final action is recommended, the DOE may wish to } \\
\text { obtain additional information such as a baseline risk } \\
\text { assessment and ecological risk assessment. Please revise } \\
\text { the text to accurately reflect the ROD language. } \\
\text { The author may wish to indicate if the additional rates will } \\
\text { mobilize DNAPL. I don't believe the air stripper is } \\
\text { designed to treat DNAPL at this time. } \\
\text { Also, if a mass reduction technology is implemented at the } \\
\text { C-400 area, the source of contamination at the NW Plume } \\
\text { would be reduced over time. }\end{array}$ & $\begin{array}{l}\text { The text will be changed to exactly what is stated } \\
\text { in the ROD: We will make it clear that the } \\
\text { current Northwest Plume O\&M system has met } \\
\text { the objective of "initiating" control of the plume. } \\
\text { However, keep in mind the first bullet in the } \\
\text { ROD states " the first location, immediately } \\
\text { north of the plant on the US DOE property is } \\
\text { intended to control the source". It is our } \\
\text { assessment that the current pumping rates may } \\
\text { not be adequate to meet this objective. }\end{array}$ \\
\hline 44 & $\begin{array}{l}\text { Eric Evans } \\
\text { Jacobs Eng. } \\
\text { General Comment }\end{array}$ & $\begin{array}{l}\text { It appears that the authors did not evaluate recent } \\
\text { groundwater modeling studies that have been conducted at } \\
\text { PGDP. The Jacobs ER Team has constructed, calibrated, } \\
\text { and documented a site-wide, groundwater flow model that } \\
\text { contains several improvements over the Georrans model } \\
\text { including: (1) greater vertical resolution and lithologic } \\
\text { detail in the UCRS; (2) more accurate definition of the } \\
\text { Porters Creek terrace location; and (3) explicit simulation } \\
\text { of the McNairy formation. Because of these improve- } \\
\text { ments, I think that this model would have been a better } \\
\text { starting place for the capture zone analysis. The authors } \\
\text { should discuss the rationale for choosing the GeoTrans } \\
\text { model for their analyses. }\end{array}$ & See Comment Response \#37 \& \#39. \\
\hline
\end{tabular}




\section{U.S: DEPARTMENT OF ENERGY OAK RIDGE OPERATIONS}

\section{DESIGN REVIEW RECORD}

Project Title: Paducah Gaseous Diffusion Plant Northwest Plume Interceptor System Evaluation Date: 11/6/96 Job Title: Alan Laase and Jay Clausen Transmittal No.:

\begin{tabular}{|c|c|c|c|}
\hline $\begin{array}{l}\text { Item } \\
\text { No. }\end{array}$ & $\begin{array}{l}\text { Drawing or spec. } \\
\text { no. \& paragraph }\end{array}$ & Comments & $\begin{array}{l}\text { A-E } \\
\text { Action }\end{array}$ \\
\hline 45 & $\begin{array}{l}\text { Eric Evans } \\
\text { Jacobs Eng. } \\
\text { General Comment }\end{array}$ & $\begin{array}{l}\text { The results of the capture zone analyses are strongly } \\
\text { controlled by the two high hydraulic conductivity zones } \\
\text { (i.e., } 2,500 \text { and } 5,000 \text { ft/day) that represent the postulated } \\
\text { ancestral channel. Both of these values are unrealistically } \\
\text { high. The hydraulic conductivity values that were assigned } \\
\text { in these zones were based on the aquifer test conducted at } \\
\text { the well fields. The assignment of the two high hydraulic } \\
\text { conductivity zones was based on the results of the aquifer } \\
\text { test analyses conducted at the two well fields (Phillips } \\
\text { 1995). The authors should have relied on the aquifer test } \\
\text { results calculated using the Hantush and Jacob leaky } \\
\text { artesian solution. This solution accounts for the vertical } \\
\text { flow of water from the UCRS to the RGA. The other } \\
\text { solutions that were used to calculate transmissivity values } \\
\text { do not account for this vertical flow. If the vertical flow } \\
\text { from the UCRS to the RGA was not important, then the } \\
\text { anthropogenic recharge discussed by the authors would } \\
\text { have little effect on water levels and velocities in the RGA. } \\
\text { The transmissivity values derived using the Hantush and } \\
\text { Jacob leaky artesian solution and presented in the aquifer } \\
\text { test report are } 32,504 \text { and } 79,780 \text { ft } / \text { /day, for the south and } \\
\text { north well fields, respectively. Assuming a RGA thickness } \\
\text { of } 50 \text { feet (based on cross-sections at the well fields), these } \\
\text { transmissivity values would yield hydraulic conductivity } \\
\text { values of } 650 \text { and } 1,595 \text { ft/day for the south and north well } \\
\text { fields, respectively. These values are much more reason- } \\
\text { able for the RGA and are more consistent with other mea- } \\
\text { sured values at the PGPD. Because recharge and hydraulic } \\
\text { conductivity are directly related, an infinite number of } \\
\text { hydraulic conductivity and recharge rate combinations will } \\
\text { yield equivalent hydraulic head distributions during the } \\
\text { model calibration. Consequently, one of the two para- } \\
\text { meters must be constrained during the model calibration } \\
\text { procedure. The authors chose to fix the hydraulic conduc- } \\
\text { tivity values in the two high hydraulic conductivity zones, } \\
\text { and the values were not adjusted during the calibration pro- } \\
\text { cedure. }\end{array}$ & $\begin{array}{l}\text { While the K values used in the model are on the } \\
\text { high end of Phillips' (1996) values we disagree } \\
\text { that the K values used are unrealistically high } \\
\text { and thus invalidate the model results. See Com- } \\
\text { ment Response \# } 19 \text {. Although, we modeled the } \\
\text { heterogeneity as a single high K zone, we } \\
\text { acknowledge that in reality we have deposits } \\
\text { several tens to } 100 \text { s of feet with high K zones } \\
\text { that may be superimposed next to different } \\
\text { deposits with varying K's. However, the level of } \\
\text { data needed to model each deposit does not exist } \\
\text { to allow modeling of heterogeneity in this } \\
\text { manner, thus we oversimplified the system. The } \\
\text { depositional environment can easily account for } \\
\text { several orders of magnitude in variation in K } \\
\text { values. The size range of material observed at the } \\
\text { site is from silty sand up to cobbles. Thus, the } \\
\text { physical data, i.e.,. very coarse soil samples, as } \\
\text { well as the pump test results support the use of a } \\
\text { high K number. Keep in mind that each subse- } \\
\text { quent pumping test at the site has resulted in an } \\
\text { increase in Ty by order of magnitude, much to } \\
\text { our surprise each time. As our understanding of } \\
\text { the system involves we are better able to predict } \\
\text { where we expect the highest T zones. }\end{array}$ \\
\hline $\begin{array}{c}45 \\
\text { cont. }\end{array}$ & $\begin{array}{l}\text { Eric Evans } \\
\text { Jacobs Eng. }\end{array}$ & $\begin{array}{l}\text { Because the authors applied hydraulic conductivity values } \\
\text { that are unrealistically high and that are not supported by } \\
\text { field data, the model calibration and the modeling results } \\
\text { are inaccurate and do not represent actual hydrogeologic } \\
\text { conditions. For a given pumping rate, the capture zones } \\
\text { that were simulated by the model will be more narrow than } \\
\text { the actual capture zones. Consequently, the revised pump- } \\
\text { ing rates presented by the authors will be much higher than } \\
\text { those needed for proper capture. The authors need to recal- } \\
\text { ibrate the model using lower hydraulic conductivity values } \\
\text { in the postulated ancestral channel and rerun the predictive } \\
\text { simulations before using the modeling results to make } \\
\text { decisions. }\end{array}$ & $\begin{array}{l}\text { See comment response \# } 19 \text {. The model will not } \\
\text { be recalibrated. Two criteria were used to evalu- } \\
\text { ate model calibration. The simulated plume had } \\
\text { to reasonably match the orientation of the } \\
\text { observed plume and model predicted heads had } \\
\text { to reasonably match } 1991 \text { water-levels. A range } \\
\text { of channel hydraulic conductivities were model- } \\
\text { ed with the model values used producing the best } \\
\text { plume match. Text will be added to the calibra- } \\
\text { tion section elaborating on calibration procedure. }\end{array}$ \\
\hline 46 & $\begin{array}{l}\text { Eric Evans } \\
\text { Jacobs Eng. } \\
\text { pg. 4-1, line } 11\end{array}$ & $\begin{array}{l}\text { PEST, and other parameter estimation codes, do not } \\
\text { necessarily produce the "best" or most realistic set of input } \\
\text { parameters. As applied in the PGDP modeling study, } \\
\text { PEST estimates model input parameters that minimize the } \\
\text { discrepancy between observed and simulated water levels } \\
\text { for the given model configuration (i.e., boundary condi- } \\
\text { tions, location and number of parameter zones, etc.). }\end{array}$ & $\begin{array}{l}\text { As stated in the text, PEST determines the best } \\
\text { set of input parameters for a given model config- } \\
\text { uration. If the model was configured differently } \\
\text { then PEST would predict an alternative set of } \\
\text { best parameter values. Therefore, the sentence is } \\
\text { correct an needs no modification. }\end{array}$ \\
\hline 47 & $\begin{array}{l}\text { Eric Evans } \\
\text { Jacobs Eng. } \\
\text { pg 5-1 }\end{array}$ & Discuss the boundary conditions in the McNairy. & $\begin{array}{l}\text { The McNairy was not included in the model. A } \\
\text { sentence will be added stating that the top of the } \\
\text { McNairy represented the bottom of the model. }\end{array}$ \\
\hline
\end{tabular}




\section{U.S. DEPARTMENT OF ENERGY OAK RDGE OPERATIONS}

\section{DESIGN REVIEW RECORD}

Project Title: Paducah Gaseous Diffusion Plant Northwest Plume Interceptor System Evaluation Date: 11/6/96 Job Title: Alan Laase and Jav Clausen Transmittal No.:

\begin{tabular}{|c|c|c|c|}
\hline $\begin{array}{l}\text { Item } \\
\text { No. }\end{array}$ & $\begin{array}{l}\text { Drawing or spec. } \\
\text { no. \& paragraph }\end{array}$ & Comments & $\begin{array}{c}\text { A-E } \\
\text { Action } \\
\end{array}$ \\
\hline 48 & $\begin{array}{l}\text { Eric Evans } \\
\text { Jacobs Eng. } \\
\text { pg. } 5-8\end{array}$ & $\begin{array}{l}\text { The assignment of the high hydraulic conductivity zone in } \\
\text { the RGA representing the inferred channel is based on } \\
\text { speculation. Please provide more direct and specific evi- } \\
\text { dence that supports your delineation of this zone. }\end{array}$ & See comment responses \# 31 and $\# 42$. . \\
\hline 49 & $\begin{array}{l}\text { Eric Evans } \\
\text { Jacobs Eng. } \\
\text { pg. 6-1; par. } 3\end{array}$ & $\begin{array}{l}\text { Discuss the fact that the "modeling results" that are used } \\
\text { during the sensitivity analysis are calculated water levels. }\end{array}$ & $\begin{array}{l}\text { Text will be added stating that model calibration } \\
\text { error is the difference between modeled and tar- } \\
\text { get heads. }\end{array}$ \\
\hline 50 & $\begin{array}{l}\text { Eric Evans } \\
\text { Jacobs Eng. } \\
\text { Table } 6.1\end{array}$ & $\begin{array}{l}\text { Did you check the correlation between recharge and } \\
\text { hydraulic conductivity? The two are almost always highly } \\
\text { correlated. }\end{array}$ & $\begin{array}{l}\text { The text states that the channel hydraulic } \\
\text { conductivities were correlated to most other in- } \\
\text { put parameters. The table reflects only the status } \\
\text { of the channel hydraulic conductivities and not } \\
\text { the other input parameters. }\end{array}$ \\
\hline 51 & $\begin{array}{l}\text { Michael Kladias } \\
\text { Jacobs Eng. } \\
\text { Executive } \\
\text { Summary } \\
\text { Par 3, line 3. }\end{array}$ & $\begin{array}{l}\text { Statement regarding eastward flow in the RGA may be } \\
\text { incorrect. Please include a contour plot depicting observed } \\
\text { eastward flow directions in the RGA. Contoured heads in } \\
\text { January } 1992 \text {, (stage=326 ft) do not reveal dominant east- } \\
\text { ward flow directions, only a flow reversal along (perpen- } \\
\text { dicular to) the Ohio River. }\end{array}$ & $\begin{array}{l}\text { Agree, the January head data does not show } \\
\text { eastward flow, however potentiometric maps for } \\
\text { May and June, } 1996 \text { as well as several other } \\
\text { prior years indicates eastward flow exists at } \\
\text { certain times. Reference to this discussion in } \\
\text { DOE/OR-07:1531\&D1 will be included. Addi- } \\
\text { tionally, potentiometric maps will not be added } \\
\text { to this report. }\end{array}$ \\
\hline 52 & $\begin{array}{l}\text { Michael Kladias } \\
\text { Jacobs Eng. } \\
\text { Section 1, Par 1, } \\
\text { Line } 8\end{array}$ & $\begin{array}{l}\text { Change sentence to state that hydraulic conductivities are } \\
\text { estimated to be } 8,000 \mathrm{ft} / \mathrm{d} \text {, I doubt that they were measured } \\
\text { directly. Also, Phillips (1996) suggested that higher trans- } \\
\text { missivities may be found in the north well field, estimated } \\
\text { transmissivities in the south well field were a factor of } 2 \text { to } \\
3 \text { lower than the north. The value of } 8,000 \mathrm{ft} / \mathrm{d} \text { may not be } \\
\text { representative of a large area. Also the values estimated in } \\
\text { the north should be used with caution since aquifer } \\
\text { thickness is small and non-uniform. Please address these } \\
\text { issues and include more detail from Phillips (1996). }\end{array}$ & $\begin{array}{l}\text { Agreed, text will be changed from measured } \\
\text { directly to estimated. The text will be reworded } \\
\text { so as not imply that K's of } 8000 \text { ft/day are re- } \\
\text { presentative of a'large area but rather represent } \\
\text { a possible upper bound. The Phillips (1996) } \\
\text { report will be referenced where appropriate. See } \\
\text { comment response \# } 19 \& 20 \text {. }\end{array}$ \\
\hline 53 & $\begin{array}{l}\text { Michael Kladias } \\
\text { Jacobs Eng. } \\
\text { Section } 2, \text { Par } 1 \text {, } \\
\text { Line } 9 .\end{array}$ & $\begin{array}{l}\text { Should be stated in the text why the GeoTrans Model was } \\
\text { modified and why this model was chosen over any other } \\
\text { models developed for the PGDP. }\end{array}$ & See comment responses \# 37, 39, and 44 . \\
\hline 54 & $\begin{array}{l}\text { Michael Kladias } \\
\text { Jacobs Eng. } \\
\text { Section 3, Par 1, } \\
\text { Line } 8\end{array}$ & $\begin{array}{l}\text { Please state exactly what is meant by bulk hydraulic } \\
\text { conductivity. I think these values are model estimated and } \\
\text { represent volumetric averaged values or homogeneous } \\
\text { equivalents. }\end{array}$ & $\begin{array}{l}\text { Bulk hydraulic conductivity, as noted in the } \\
\text { comment, represents homogeneous equivalent } \\
\text { hydraulic conductivity. The authors believe bulk } \\
\text { hydraulic conductivity is self explanatory and } \\
\text { needs no further definition. }\end{array}$ \\
\hline 55 & $\begin{array}{l}\text { Michael Kladias } \\
\text { Jacobs Eng. } \\
\text { Section } 3 \text {, Par 1, } \\
\text { Line } 19\end{array}$ & $\begin{array}{l}\text { Text states that the McNairy formation hydraulic } \\
\text { conductivity has never been measured, but GeoTrans } \\
\text { (1992) states that average slug test values (from regional } \\
\text { studies) are about } 0.24 \mathrm{ft} / \mathrm{d} \text { (CH2M Hill 1991). This } \\
\text { suggests that the McNairy is as permeable as the UCRS is } \\
\text { in some locations. Please address this issue. }\end{array}$ & $\begin{array}{l}\text { Text will be changed to say that McNairy hy- } \\
\text { draulic conductivity values have not been } \\
\text { measured in situ at PGDP. The regional slug test } \\
\text { data referenced in the comment has been judged } \\
\text { unreliable and nonrepresentative (Kilby and } \\
\text { McConnel, } 1993 \text { in KY/ER-34). In some areas } \\
\text { it may be possible that the upper McNairy is as } \\
\text { permeable as the UCRS. However, both the } \\
\text { UCRS and McNairy have significantly lower } \\
\text { hydraulic conductivities than the RGA. }\end{array}$ \\
\hline 56 & $\begin{array}{l}\text { Michael Kladias } \\
\text { Jacobs Eng. } \\
\text { Section 3, Par 2, } \\
\text { Line 1. }\end{array}$ & $\begin{array}{l}\text { This statement is incorrect, I do not believe the PCC } \\
\text { bounds the McNairy formation in the south. Please restate } \\
\text { that only the UCRS and RGA terminate in the south at the } \\
\text { PCC Terrace. }\end{array}$ & Text will be changed. \\
\hline
\end{tabular}




\section{U.S. DEPARTMENT OF ENERGY OAK RIDGE OPERATIONS}

\section{DESIGN REVIEW RECORD}

Project Title: Paducah Gaseous Diffusion Plant Northwest Plume Interceptor System Evaluation Date: 11/6/96 Job Title: Alan Laase and Jay Clausen

\begin{tabular}{|c|c|c|c|}
\hline $\begin{array}{l}\text { Item } \\
\text { No. }\end{array}$ & $\begin{array}{l}\text { Drawing or spec. } \\
\text { no. \& paragraph }\end{array}$ & Comments & $\begin{array}{c}\text { A-E } \\
\text { Action } \\
\end{array}$ \\
\hline 57 & $\begin{array}{l}\text { Michael Kladias } \\
\text { Jacobs Eng. } \\
\text { Section 5. Par } 1 \\
\text { Line 1. }\end{array}$ & $\begin{array}{l}\text { Please state if any other models, such as those by } \\
\text { McConnell or the Jacobs ER Team (DOE 1994,1996), } \\
\text { were examined during recalibration. Also see comment } 3 \text {. }\end{array}$ & No. \\
\hline 58 & $\begin{array}{l}\text { Michael Kladias } \\
\text { Jacobs Eng. } \\
\text { Section 5.1, Par 1, } \\
\text { Line 11. }\end{array}$ & $\begin{array}{l}\text { Text states that the in the original implementation of the } \\
\text { GeoTrans model the effects of the McNairy were insigni- } \\
\text { ficant. Explain why this still applies with the recalibrated } \\
\text { model. If the GeoTrans model was incorrectly calibrated } \\
\text { how do you know the effects of McNairy were handled } \\
\text { correctly? Please provide additional information as to why } \\
\text { the McNairy can be deleted. See comment } 5 \text {. }\end{array}$ & $\begin{array}{l}\text { What is meant by "incorrectly calibrated"? The } \\
\text { GeoTrans model was, according to the GeoTrans } \\
\text { modelers, successfully calibrated against target } \\
\text { observations. Rather than incorrectly calibrated, } \\
\text { within the GeoTrans model the McNairy was } \\
\text { perhaps incorrectly configured. GeoTrans repre- } \\
\text { sented the McNNairy as a series of constant head } \\
\text { nodes. Therefore, within the GeoTrans model } \\
\text { RGA hydraulic head values control movement of } \\
\text { water into the McNairy. The GeoTrans model } \\
\text { and this model were calibrated to the same RGA } \\
\text { target hydraulic head values. Although there } \\
\text { were differences in the degree of RGA calibra- } \\
\text { tion, both models reasonably matched the RGA } \\
\text { target values. Thus, for the two models, it is } \\
\text { unlikely that there would have been significant } \\
\text { differences in flow between the RGA and } \\
\text { McNairy. } \\
\text { The authors do not believe that additional justi- } \\
\text { fication for removing the McNairy beyond that } \\
\text { already presented is warranted. Thus, no chan- } \\
\text { ges will be made to the text. }\end{array}$ \\
\hline 59 & $\begin{array}{l}\text { Michael Kladias } \\
\text { Jacobs Eng. } \\
\text { Section 5.2, } \\
\text { Par 1, Line 1. }\end{array}$ & $\begin{array}{l}\text { What is the rationale for not adjusting boundary conditions } \\
\text { in the GeoTrans (1992) model? The Jacobs ER Team } \\
\text { model (DOE, 1994) showed that with updated structural } \\
\text { data, the intake channel near TVA actually cuts into the } \\
\text { alluvial deposits along the Ohio River. This results in im- } \\
\text { proved simulated flow directions in the RGA. }\end{array}$ & We weren't aware of any updated structural data. \\
\hline 60 & $\begin{array}{l}\text { Michael Kladias } \\
\text { Jacobs Eng. } \\
\text { Section 5.3, } \\
\text { Par 2, Line } 9\end{array}$ & $\begin{array}{l}\text { What is the reference for the } 001 \text { Outfall ditch leakage rate } \\
\text { of } 1.4 \mathrm{mg} / \mathrm{d} \text { ? }\end{array}$ & See comment response \# 28. \\
\hline 61 & $\begin{array}{l}\text { Michael Kiadias } \\
\text { Jacobs Eng. } \\
\text { Section 5.3, } \\
\text { Par 2, Line } 13 .\end{array}$ & $\begin{array}{l}\text { Why was recharge not eliminated in areas where caps or } \\
\text { liners exist (WAG22, SWMU } 3 \text { ) in addition to building } \\
\text { and paved areas? }\end{array}$ & See comment response \# 1 and 23. \\
\hline 62 & $\begin{array}{l}\text { Michael Kladias } \\
\text { Jacobs Eng. } \\
\text { Section 5.4, Par 1, } \\
\text { Line 6. }\end{array}$ & See comment 2. & See comment response $\# 19,20$, and 52 . \\
\hline 63 & $\begin{array}{l}\text { Michael Kladias } \\
\text { Jacobs Eng. } \\
\text { Section 6.1, Par 1, } \\
\text { Line 1. }\end{array}$ & $\begin{array}{l}\text { Please explain why } 1991 \text { data was used instead of more } \\
\text { recent water level data from } 1992 \text { that may yield better } \\
\text { spatial coverage of water levels? Was any evaluation per- } \\
\text { formed to determine a more suitable steady-state calibra- } \\
\text { tion period, i.e., September or October? }\end{array}$ & $\begin{array}{l}\text { The spatial distribution of data was deemed suf- } \\
\text { ficient and an analysis to determine suitable tar- } \\
\text { get data was beyond the scope of the project. } \\
\text { The } 1991 \text { date was deemed by LMES and } \\
\text { GeoTrans to be indicative of base level condi- } \\
\text { tions. }\end{array}$ \\
\hline
\end{tabular}




\section{U.S. DEPARTMENT OF ENERGY OAK RIDGE OPERATIONS}

\section{DESIGN REVIEW RECORD}

\begin{tabular}{|c|c|c|c|}
\hline \multicolumn{4}{|c|}{$\begin{array}{l}\text { Project Title: } \frac{\mathrm{P}}{\mathrm{A}} \\
\text { Job Title: }\end{array}$} \\
\hline $\begin{array}{l}\text { Item } \\
\text { No. }\end{array}$ & $\begin{array}{l}\text { Drawing or spec. } \\
\text { no. \& paragraph }\end{array}$ & Comments & $\begin{array}{c}\text { A-E } \\
\text { Action } \\
\end{array}$ \\
\hline 64 & $\begin{array}{l}\text { Michael Kladias } \\
\text { Jacobs Eng. } \\
\text { Section 6.1, Par 1, } \\
\text { Line 1. }\end{array}$ & $\begin{array}{l}\text { Doherty et al. (1994) states the following with regard to } \\
\text { confidence limits: } \\
\text { "...parameter confidence limits are calculated on the basis } \\
\text { of the same linearity assumptions which was used to derive } \\
\text { the equations for parameter improvement. No account is } \\
\text { taken of parameter upper and lower bounds in calculation } \\
\text { of } 95 \% \text { confidence intervals. Thus an upper or lower con- } \\
\text { fidence limit can lie well outside a parameter's allowed } \\
\text { domain. } \\
\text { The parameter confidence intervals are highly depen- } \\
\text { dent on the assumptions underpinning the model. If the } \\
\text { model has too few parameters to accurately simulate a } \\
\text { particular system, the optimized objective function will } \\
\text { be large and so too will be the parameters covariances } \\
\text { and, with them, the parameter confidence intervals. } \\
\text { 'The sole purpose of the confidence intervals provided by } \\
\text { PEST is as a means of comparing the certainty with which } \\
\text { different parameters values are estimated. They have no } \\
\text { physical significance. In many cases the confidence limits } \\
\text { (error estimate) are far greater than the actual parameter } \\
\text { value in question. Please explain how these confidence } \\
\text { intervals relate to an uncertainty analysis that should evalu- } \\
\text { ate the potential range in a parameter based on field obser- } \\
\text { vations or measurements. Also, why was the observed } \\
\text { range in parameters not used in the uncertainty analysis? }\end{array}$ & $\begin{array}{l}\text { Although it is possible for } 95 \% \text { confidence para- } \\
\text { meter extremes to be outside expected parameter } \\
\text { ranges this is not the case with this model. With } \\
\text { the exception of the RGA Ohio River hydraulic } \\
\text { conductivity, the model input parameter } 95 \% \\
\text { confidence intervals are relatively narrow sug- } \\
\text { gesting confident and reasonable predictions. } \\
\text { The } 95 \% \text { confidence interval for the RGA Ohio } \\
\text { River hydraulic conductivity spans two orders of } \\
\text { magnitude with the extremes being believable } \\
\text { values. Thus, estimated parameter } 95 \% \text { confi- } \\
\text { dence interval extremes are with reasonable } \\
\text { limits and are, for this model, meaningful. } \\
\text { The applicability of } 95 \% \text { confidence intervals for } \\
\text { sensitivity analysis is currently being debated } \\
\text { among inverse modeler practitioners and develo- } \\
\text { pers with no clear concensus. Some practio- } \\
\text { ners/developers prefer actual parameter ranges } \\
\text { and others prefer } 95 \% \text { confidence intervals. } \\
\text { For parameters such as recharge and Ohio River } \\
\text { hydraulic conductivity which have never been } \\
\text { directly measured at the site observed parameter } \\
\text { ranges are not available. We believe, for these } \\
\text { parameters, use of } 95 \% \text { confidence intervals is } \\
\text { more reasonable than arbitrarily selecting mini- } \\
\text { mum and maximum values. }\end{array}$ \\
\hline 65 & $\begin{array}{l}\text { Michael Kladias } \\
\text { Jacobs Eng. } \\
\text { Section 6.1, Par. 3, } \\
\text { Line 4, Fig. 6.1 }\end{array}$ & $\begin{array}{l}\text { What is the rationale for including RGA channel (middle) } \\
\text { zone in the model since it is completely insensitive and sta- } \\
\text { tistically insignificant to the model? Typically, insensitive } \\
\text { zones are to be coupled with sensitive zones to add credi- } \\
\text { bility to model estimated values. How was "optimized } \\
\text { value" of the zone selected? }\end{array}$ & $\begin{array}{l}\text { The two channel hydraulic conductivity zones } \\
\text { are insensitive with respect to hydraulic head but } \\
\text { are sensitive to particle migration. The two } \\
\text { channel hydraulic conductivity values used in } \\
\text { the model resulted in the best match between } \\
\text { particle traces and plume geometry. }\end{array}$ \\
\hline 66 & $\begin{array}{l}\text { Michael Kladias } \\
\text { Jacobs Eng. } \\
\text { Section 6.1, Par 3, } \\
\text { Line 4, Fig. 6.1 }\end{array}$ & $\begin{array}{l}\text { As described in the report in Section } 3 \text { the primary flow } \\
\text { direction in the UCRS is downward. Why were vertical } \\
\text { conductances not estimated in the model and/or sensitivity } \\
\text { analyses performed on this parameter? If flow is primarily } \\
\text { downward, the vertical conductance between model layers } \\
1 \text { and } 2 \text { should be extremely sensitive. Please address the } \\
\text { sensitivity if vertical conductance values. }\end{array}$ & $\begin{array}{l}\text { Vertical hydraulic conductivities proved to be } \\
\text { extremely sensitive. In fact, minimal changes in } \\
\text { the input values resulted in nonconvergence. } \\
\text { Vertical hydraulic conductivity values will be } \\
\text { listed in Table } 6.1 \text { along with input parameters } \\
\text { and an explanation as to why the parameter was } \\
\text { not estimated using inverse techniques will be } \\
\text { included. }\end{array}$ \\
\hline 67 & $\begin{array}{l}\text { Michael Kladias } \\
\text { Jacobs Eng. } \\
\text { Section } 6.2, \text { Par } 2 \text {, } \\
\text { Line } 6\end{array}$ & $\begin{array}{l}\text { Explain how the model predicted confidence limits justify } \\
\text { the value actually used in the calibrated model. The confi- } \\
\text { dence limits only indicate to the user the range in values } \\
\text { that are statistically significant to the model calibration. } \\
\text { See comment } 14 \text {. }\end{array}$ & See comment response \#64. \\
\hline 68 & $\begin{array}{l}\text { Michael Kladias } \\
\text { Jacobs Eng. } \\
\text { Section 6.2, Par 4, } \\
\text { Line 4. }\end{array}$ & See comment 10. & See comment response \#28. \\
\hline
\end{tabular}
Job Title: Alan Laase and Jay Clausen

Evaluation Date: 11/6/96 


\begin{tabular}{|c|c|c|c|}
\hline \multicolumn{3}{|c|}{$\begin{array}{l}\text { U.S. DEPARTMENT OF ENERGY } \\
\text { OAK RIDGE OPERATIONS }\end{array}$} & $\begin{array}{l}\text { DESIGN. } \\
\text { REVIEW RECORD }\end{array}$ \\
\hline \multicolumn{4}{|c|}{$\begin{array}{l}\text { Project Title: } \\
\text { Job Title: }\end{array} \frac{\text { Paducah Gaseous Diffusion Plant Northwest Plume Interceptor System Evaluation Daase and Jay Clausen }}{\text { Alan Late: }}$} \\
\hline $\begin{array}{l}\text { Item } \\
\text { No. }\end{array}$ & $\begin{array}{l}\text { Drawing or spec. } \\
\text { no. \& paragraph }\end{array}$ & Comments & $\begin{array}{l}\text { A-E } \\
\text { Action }\end{array}$ \\
\hline 69 & $\begin{array}{l}\text { Michael Kladias } \\
\text { Jacobs Eng. } \\
\text { Section } 6.3 \\
\text { Table } 6.3\end{array}$ & $\begin{array}{l}\text { These calibration statistics are only marginally improved } \\
\text { over the GeoTrans (1992) calibration. Please post the resi- } \\
\text { duals on the calibrated head plots for model layers } 1 \text { and } 2 \text {. } \\
\text { The Residual Mean of }-1.25 \text { may indicate significant } \\
\text { spatial bias, please explain if any bias exists and why? It } \\
\text { appears that the model generally over predicts water levels. } \\
\text { Also please explain or provide a reference for how the } \\
\text { calibration statistics are calculated. }\end{array}$ & $\begin{array}{l}\text { Because of readability the residuals will not be } \\
\text { added to the hydraulic head plots for layer } 1 \text { and } \\
2 \text {. The information requested can be obtained } \\
\text { from the scatter plot shown in Fig. } 6.6 \text {. A } \\
\text { reference will be added to Table } 6.3 \text { referencing } \\
\text { the statistic formula source. }\end{array}$ \\
\hline 70 & $\begin{array}{l}\text { Michael Kladias } \\
\text { Jacobs Eng. } \\
\text { Section 6.4, Par 4, } \\
\text { Line 1. }\end{array}$ & $\begin{array}{l}\text { Please show additional particle traces to delineate exactly } \\
\text { how the model represents the Northeast Plume. From the } \\
\text { figures included in this report it does not appear that the } \\
\text { model accurately simulates Northeast Plume flow direc- } \\
\text { tions. }\end{array}$ & $\begin{array}{l}\text { It was never the intent of this model to simulate } \\
\text { the Northeast plume. The authors simply wanted } \\
\text { to illuminate the possibility that the C-400 } \\
\text { Building could be a source of both the northeast } \\
\text { and northwest plumes. No claims to accurate } \\
\text { portrayal of the Northeast plume are made in the } \\
\text { report. The report states that if the eastem model } \\
\text { boundary was located further to the east the } \\
\text { particle traces might follow the path of the } \\
\text { northeast plume. }\end{array}$ \\
\hline 71 & $\begin{array}{l}\text { Michael Kladias } \\
\text { Jacobs Eng. } \\
\text { Section 6.4, Par 4, } \\
\text { Line 4. }\end{array}$ & $\begin{array}{l}\text { Given this statement that the model does not simulate the } \\
\text { Northeast Plume, how does this affect the results for the } \\
\text { Northwest Plume presented in this report? }\end{array}$ & See comment response \#70. \\
\hline 72 & $\begin{array}{l}\text { Michael Kladias } \\
\text { Jacobs Eng. } \\
\text { Section 6.4, Par 4, } \\
\text { Line 5. }\end{array}$ & $\begin{array}{l}\text { How is this statement relevant, since the model may never } \\
\text { simulate the Northeast Plume in its current form? }\end{array}$ & See comment response \#70 \\
\hline 73 & $\begin{array}{l}\text { Michael Kladias } \\
\text { Jacobs Eng. } \\
\text { Section } 6.4, \text { Par } 5 \\
\text { Line } 6 .\end{array}$ & $\begin{array}{l}\text { How can this statement be made since potential errors as } \\
\text { stated in Section } 8 \text { may exist in the model because the } \\
\text { UCRS is possibly under-discretized? Please qualify this } \\
\text { statement. }\end{array}$ & $\begin{array}{l}\text { The statement is already qualified by the use of } \\
\text { terms such as "of interest", "while not conclu- } \\
\text { sive", "could be responsible". The paragraph is } \\
\text { not intended to be definitive. }\end{array}$ \\
\hline 74 & $\begin{array}{l}\text { Michael Kladias } \\
\text { Jacobs Eng. } \\
\text { Section 7.2, Par 3, } \\
\text { Line 1 }\end{array}$ & See comment 14 . & See comment response \#64. \\
\hline 75 & $\begin{array}{l}\text { Michael Kladias } \\
\text { Jacobs Eng. } \\
\text { Section 7.2, Par 4, } \\
\text { Line 1 }\end{array}$ & $\begin{array}{l}\text { How does a travel time or pore volume exchange time of } \\
10 \text { years correspond to the source timing for the Northwest } \\
\text { Plume. Is this travel time reasonable and why hasn't the } \\
\text { plume already reached the Ohio River at that rate? Also } \\
\text { state what porosity was used to compute pore volume } \\
\text { exaggerate and travel times. }\end{array}$ & $\begin{array}{l}\text { Porosities will be added to the report. Given the } \\
\text { correlation of Ohio River stage and RGA water- } \\
\text { Ilevels it is possible that the plume has already } \\
\text { reached the Ohio River but can not be detected } \\
\text { because of the mixing of river and RGA water. } \\
\text { Thus, the front of the plume is probably a poor } \\
\text { indicator of groundwater travel times. }\end{array}$ \\
\hline
\end{tabular}




\section{U.S. DEPARTMENT OF ENERGY OAK RIDGE OPERATIONS}

\section{DESIGN REVIEW RECORD}

Project Title: Paducah Gaseous Diffusion Plant Northwest Plume Interceptor System Evaluation Date: 11/6/96 Job Title: Alan Laase and Jay Clausen Transmittal No.:

\begin{tabular}{|c|c|c|c|}
\hline $\begin{array}{l}\text { Item } \\
\text { No. }\end{array}$ & $\begin{array}{l}\text { Drawing or spec. } \\
\text { no. \& paragraph }\end{array}$ & Comments & $\begin{array}{c}\text { A-E } \\
\text { Action } \\
\end{array}$ \\
\hline 76 & $\begin{array}{l}\text { Michael Kladias } \\
\text { Jacobs Eng. } \\
\text { Section 8, Par 1, } \\
\text { Line 3. }\end{array}$ & $\begin{array}{l}\text { According to Konikow (1978) "Ideally the error in the } \\
\text { water balance is less than 0.1\%. However, an error of } \\
\text { around } 1 \% \text { is usually considered acceptable." In large } \\
\text { domain models containing large inflows and outflows, the } \\
\text { solver head convergence criteria must be set to an } \\
\text { exceptionally small value to reduce overall and subregional } \\
\text { model errors. Errors of } 50 \% \text { are unacceptable and suggest } \\
\text { that the model was not fully converged. What attempts } \\
\text { were made to reduce the flow balance error? How are the } \\
\text { results presented in this report justified if the mass errors } \\
\text { are so large? The large mass balance errors are most likely } \\
\text { the results of a large convergence criteria and extremely } \\
\text { high hydraulic conductivities in the RGA. Explain how } \\
\text { additional layers will reduce the mass balance errors since } \\
\text { the overall flow from the UCRS to the RGA should not } \\
\text { change? }\end{array}$ & $\begin{array}{l}\text { We recognize that the mass balance of the model } \\
\text { is less than ideal and expended considerable } \\
\text { effort attempting to locate and reduce the error. } \\
\text { The error is not associated with large conver- } \\
\text { gence criteria or the addition of high hydraulic } \\
\text { conductivity zones as implied in the comment. } \\
\text { The convergence criteria for the model was } 10^{3} \\
\text { feet. The GeoTrans model did not include high } \\
\text { hydraulic conductivity zones and suffered from } \\
\text { the same mass balance problems. Evaluation of } \\
\text { cell-by-cell flow terms showed that the greatest } \\
\text { mass balance error was associated with areas of } \\
\text { the model having the greatest UCRS to RGA } \\
\text { head differential. The combination of large head } \\
\text { differential and relatively small vertical hy- } \\
\text { draulic conductivity results in large mass balance } \\
\text { errors. Adding additional UCRS model layers } \\
\text { would redue the head differential between } \\
\text { model layers and thus the mass balance error. }\end{array}$ \\
\hline 77 & $\begin{array}{l}\text { Michael Kladias } \\
\text { Jacobs Eng. } \\
\text { Section } 8 \text {, Par } 6 \text {, } \\
\text { Line } 4 \text { and } \\
\text { Section } 8, \text { Par } 7 \text {, } \\
\text { Line } 1\end{array}$ & $\begin{array}{l}\text { Both the terrace gravels and the McNairy formation were } \\
\text { simulated in the Jacobs ER Team model (DOE 1996). } \\
\text { Both were found to be extremely important to the model } \\
\text { calibration. The Jacobs ER Team model resulted in a much } \\
\text { closer fit to observed data than the GeoTrans model } \\
\text { (RSS }=148.4 \text {, STD }=1.37 \text {, RMEAN }=-0.196 \text { ft). Since a re- } \\
\text { calibration effort was undertaken in this study why wasn't } \\
\text { the.Jacobs ER Team model used or the GeoTrans (1992) } \\
\text { model revised to include these features? }\end{array}$ & $\begin{array}{l}\text { As stated previously, changing the extent of the } \\
\text { GeoTrans model domain was beyond the scope } \\
\text { of this project. At the time the decision was } \\
\text { made to use the GeoTrans model we were not } \\
\text { aware of the "improved" features in the Jacobs } \\
\text { model. }\end{array}$ \\
\hline 78 & $\begin{array}{l}\text { Michael Kladias } \\
\text { Jacobs Eng. } \\
\text { Section 10, Par } 2\end{array}$ & See Comment 27. & See comment response \#77. \\
\hline 79 & $\begin{array}{l}\text { Michael Kladias } \\
\text { Jacobs Eng } \\
\text { Section 10, Par } 4\end{array}$ & See Comment 27 & See comment response \#27. \\
\hline 80 & $\begin{array}{l}\text { Michael Kladias } \\
\text { Jacobs Eng } \\
\text { Figures }\end{array}$ & $\begin{array}{l}\text { Consider black and white figures for easier report repro- } \\
\text { duction. }\end{array}$ & $\begin{array}{l}\text { Given figure detail, color figures improve report } \\
\text { comprehension. }\end{array}$ \\
\hline
\end{tabular}




\section{INTERNAL DISTRIBUTION}

1. N. E. Korte

2 - 6. A. D. Laase

7 - 11. C. A. Little

12. R. C. Mann

13. L. E. Toran

14. J. E. Wilson
15. Central Research Library

16 - 17. Laboratory Records

18. Laboratory Records - RC

19. ORNL Patent Section

20. ORNL Technical Library, Y-12

\section{EXTERNAL DISTRIBUTION} 21 - 30. Jay Clausen, Ogden Environmental, 239 Littleton Road, Suite 1B, Westford, MA
01886

31. Office of Assistant Manager, Energy Research and Development, Oak Ridge Operations Office, P.O. Box 2001, Oak Ridge, TN 37831-8600

32 - 41. Office of Scientific and Technical Information, U.S. Department of Energy, P.O. Box 62, Oak Ridge, TN 37831 